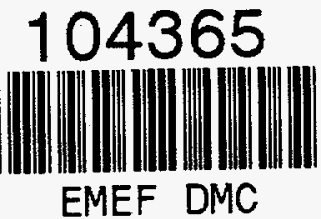

LOCKHEED MARTIN/7

ORNL/ER-423

ENVIRONMENTAL

RESTORATION

PROGRAM

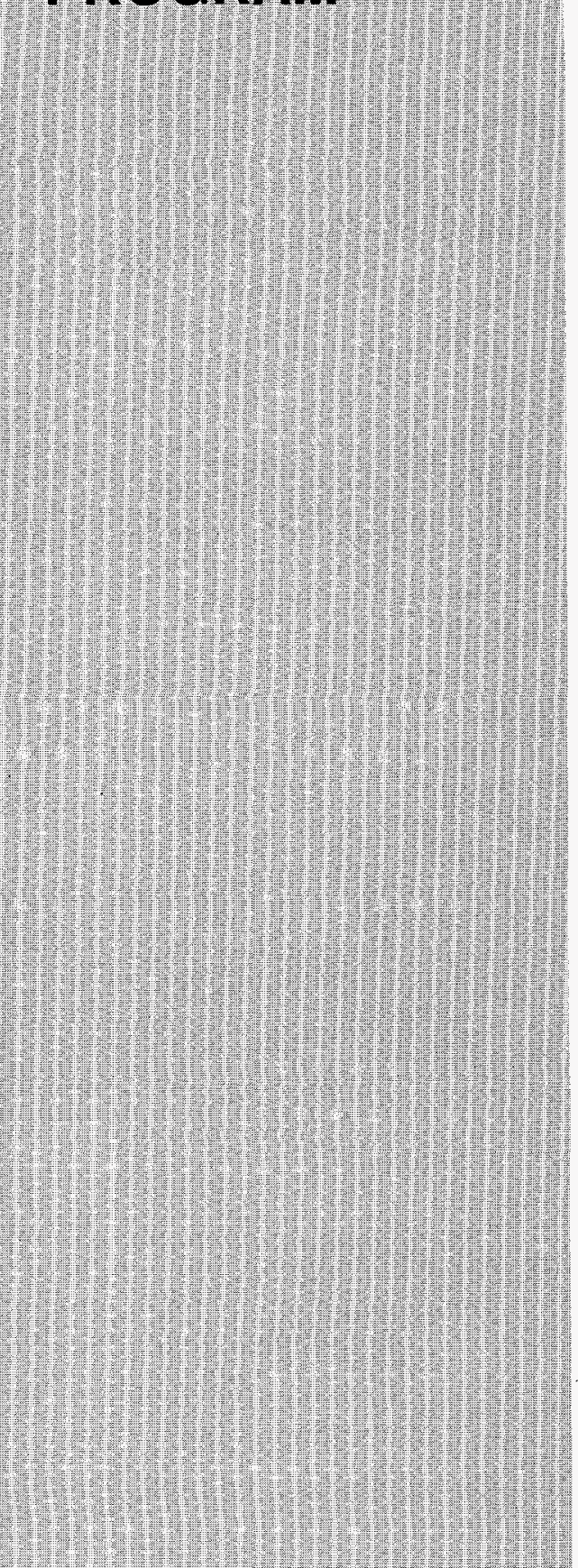

MANAGEDBY

LOCKHEED MARTIN ENERGY SYSTEMS, INC.

FOR THE UNITED STATES

DEPARTMENT OF ENERGY

\section{Cold Test Plan}

for the Old Hydrofracture Facility

Tank Contents Removal Project,

Oak Ridge National Laboratory, Oak Ridge, Tennessee

This document has been approved by the ORNL Technical Information Office for release to the public. Date: $12 / 18 / 97$

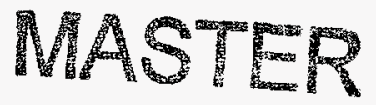




\begin{tabular}{|l|}
\hline \multicolumn{1}{|c|}{ CDM Federal Programs Corp. } \\
contributed to the preparation of this document and should not be \\
considered and eligible contractor for its review.
\end{tabular}




\section{DISCLAIMER}

This report was prepared as an account of work sponsored by an agency of the United States Government. Neither the United States Government nor any agency thereof, nor any of their employees, makes any warranty, express or implied, or assumes any legal liability or responsibility for the accuracy, completeness, or usefulness of any information, apparatus, product, or process disclosed, or represents that its use would not infringe privately owned rights. Reference herein to any specific commercial product, process, or service by trade name, trademark, manufacturer, or otherwise does not necessarily constitute or imply its endorsement, recommendation, or favoring by the United States Government or any agency thereof. The views and opinions of authors expressed herein do not necessarily state or reflect those of the United States Government or any agency thereof. 


\section{DISCLAIMER}

Portions of this document may be illegible electronic image products. Images are produced from the best available original document. 


\title{
Cold Test Plan \\ for the Old Hydrofracture Facility Tank Contents Removal Project, Oak Ridge National Laboratory, Oak Ridge, Tennessee
}

Date Issued—November 1997

\author{
Prepared by \\ CDM Federal Program Corporation \\ Oak Ridge, Tennessee 37830 \\ under subcontract 13B-99313C \\ Document Control No. 5151-015-FR-BBSP
}

Prepared for the

U.S. Department of Energy

Office of Environmental Management

under budget and reporting code EW 20

Environmental Management Activities at the OAK RIDGE NATIONAL LABORATORY

Oak Ridge, Tennessee 37831

managed by

LOCKHEED MARTIN ENERGY SYSTEMS, INC.

for the

U.S. DEPAR'TMENT OF ENERGY

under contract DE-AC05-84OR21400 


\begin{tabular}{|c|c|c|c|}
\hline \multicolumn{4}{|c|}{$\begin{array}{l}\text { RESPONSES TO COMMENTS ON THE COLD TEST PLAN FOR } \\
\text { THE OLD HYDROFRACTURE FACILITY TANK CONTENTS REMOVAL PROJECT AT } \\
\text { THE OAK RIDGE NATIONAL LABORATORY, OAK RIDGE, TENNESSEE }\end{array}$} \\
\hline \begin{tabular}{|l} 
Item \\
No.
\end{tabular} & $\begin{array}{l}\text { Page, Paragraph, and } \\
\text { Line }\end{array}$ & Comment & Resolution \\
\hline \multicolumn{4}{|c|}{ Reviewer: DOE } \\
\hline 1. & General & No comments. & \\
\hline \multicolumn{4}{|c|}{ Reviewer: J. Alexander } \\
\hline \multicolumn{4}{|c|}{ General Comments } \\
\hline 1. & General & $\begin{array}{l}\text { I reviewed OHF-140 and found nothing that has impact on nuclear } \\
\text { criticality safety or facility radiological safety except indirectly } \\
\text { through valve-sequence manipulation that may be carried over to } \\
\text { the actual sluicing and mixing. Review of actual working } \\
\text { procedures will identify any potential NCS issues. }\end{array}$ & Noted. \\
\hline 2. & General & $\begin{array}{l}\text { Is it true that radiological safety concerns will be addressed } \\
\text { because of a requirement for radiation worker training? The area } \\
\text { health physicist or area RCT may wish to include some } \\
\text { information about requirements for conforming to the radiation } \\
\text { work permit in the exam. }\end{array}$ & $\begin{array}{l}\text { Noted. Radiological conirol practices will be rehearsed } \\
\text { during maintenance exercises. The project-specific HASP } \\
\text { also emphasizes compliance with the RWP for the specific } \\
\text { task. }\end{array}$ \\
\hline 3. & Appendix C & $\begin{array}{l}\text { The examination is not appropriate and is at least partially } \\
\text { incorrect. It does not address NCS requirements from the NCSA. } \\
\text { If requested, the NCS Section will work with the facility manager } \\
\text { and responsible supervisor to ensure appropriate topics are } \\
\text { covered. }\end{array}$ & $\begin{array}{l}\text { Noted. The exam was developed to help demonstrate that } \\
\text { operators satisfy an appropriate level of competency. Since } \\
\text { no specific exam deficiencies were identified, no changes } \\
\text { have been made. Specific comments or suggestions on the } \\
\text { exam are welcomed. }\end{array}$ \\
\hline \multicolumn{4}{|c|}{ Reviewer: S. M. Babcock } \\
\hline \multicolumn{4}{|c|}{ General Comments } \\
\hline 1. & Appendix A & $\begin{array}{l}\text { Checklists in general-Shouldn't there be a spot where it is } \\
\text { verified that the data desired has been collected and stored and the } \\
\text { appropriate video tapes have been collected and labeled and } \\
\text { stored. }\end{array}$ & $\begin{array}{l}\text { The key data for the tests are recorded on the checklists. } \\
\text { Videotapes will be used during training as a training aid } \\
\text { and permitting aid. }\end{array}$ \\
\hline
\end{tabular}




\begin{tabular}{|c|c|c|c|}
\hline \multicolumn{4}{|c|}{$\begin{array}{l}\text { RESPONSES TO COMMENTS ON THE COLD TEST PLAN FOR } \\
\text { THE OLD HYDROFRACTURE FACILITY TANK CONTENTS REMOVAL PROJECT AT } \\
\text { THE OAK RIDGE NATIONAL LABORATORY, OAK RIDGE, TENNESSEE }\end{array}$} \\
\hline $\begin{array}{l}\text { Item } \\
\text { No. }\end{array}$ & $\begin{array}{l}\text { Page, Paragraph, and } \\
\text { Line }\end{array}$ & Comment & Resolution \\
\hline \multicolumn{4}{|c|}{ Specific Comments } \\
\hline 1. & $\begin{array}{l}\text { Pages } 2-3 \text { and } 2-4 \text {, } \\
\text { Figures } 2.2 \text { and } 2.3\end{array}$ & $\begin{array}{l}\text { Was there any consideration of how the tanks would be cleaned } \\
\text { during decommissioning following cold tests, e.g., drains to make } \\
\text { washing out the tanks easier. (NOT A COMMENT FOR THE TEST } \\
\text { PLAN, JUST A QUESTION.) }\end{array}$ & $\begin{array}{l}\text { Comment deferred to Energy Systems. The tanks have } \\
\text { been fitted with drains. }\end{array}$ \\
\hline 2. & $\begin{array}{l}\text { Pages } 2-3 \text { and } 4-34 \text {, } \\
\text { ligures } 2.3 \text { and } 4.8\end{array}$ & $\begin{array}{l}\text { Figures } 2.3 \text { and } 4.8 \text { don't agree. One shows two risers and the } \\
\text { other shows three (although nothing is connected to the central } \\
\text { riser). }\end{array}$ & $\begin{array}{l}\text { The tanks at the cold test will have two risers. All figures } \\
\text { will be revised to reflect this. }\end{array}$ \\
\hline 3. & Page 3-3 & $\begin{array}{l}\text { What specific data will be logged? Maybe this should be given for } \\
\text { each test/subtest? My particular interest is in the sluicing tests in } \\
4.5 \text { and } 4.6 \text {. }\end{array}$ & $\begin{array}{l}\text { Twenty-four different parameters are logged by the PLC as } \\
\text { part of its program. A table listing these parameters has } \\
\text { been added to Chap. } 3 \text {. }\end{array}$ \\
\hline 4. & Page 4-1 & $\begin{array}{l}\text { Since the PLC is used in test } 4.1 \text {, why is that not preceded by test } \\
4.2 ?\end{array}$ & $\begin{array}{l}\text { Test } 4.2 \text { tests the loops and ladder logic of PLC while } \\
\text { Test } 4.1 \text { tests for leaks. While there is crossover, CDM } \\
\text { Federal feels the leak test is the appropriate test to begin } \\
\text { with as all other tests will need a leak-tight system for } \\
\text { successful completion. }\end{array}$ \\
\hline 5. & Page 4-11 & Checklist 4.2 .5 .48 is missing. & The checklist has been added. \\
\hline 6. & Page $4-31, \S 4.5 .1$ & $\begin{array}{l}\text { It seems that here and elsewhere in the document, the initial } \\
\text { conditions of the test should be stated, e.g., how much sludge is in } \\
\text { the sluice tank. }\end{array}$ & Comment incorporated. \\
\hline
\end{tabular}




\begin{tabular}{|c|c|c|c|}
\hline \multicolumn{4}{|c|}{$\begin{array}{l}\text { RESPONSES TO COMMENTS ON THE COLD TEST PLAN FOR } \\
\text { THE OLD HYDROFRACTURE FACILITY TANK CONTENTS REMOVAL PROJECT AT } \\
\text { THE OAK RIDGE NATIONAL LABORATORY, OAK RIDGE, TENNESSEE }\end{array}$} \\
\hline $\begin{array}{l}\text { Item } \\
\text { No. }\end{array}$ & $\begin{array}{l}\text { Page, Paragraph, and } \\
\text { Line }\end{array}$ & Comment & Resolution \\
\hline 7. & Page $4-35, \S 4.6 .1$ & $\begin{array}{l}\text { "During this practice, various flow rates, pressures and sluicing } \\
\text { patterns will be tried to determine the most efficient sluicing } \\
\text { method and to familiarize the operators with the system." There } \\
\text { doesn't appear to be any description of the number of tests (only } \\
\text { one is specified) or the test conditions, e.g., pressures, flows, } \\
\text { sweep patterns, etc. From PNNL's perspective, this is the most } \\
\text { important step in the test plan and needs to be elaborated upon. } \\
\text { What specific data will be collected? Section } 4.6 \text { checklists are not } \\
\text { included in Appendix A. What methodology will be used to } \\
\text { determine "most efficient sluicing method" from what set of } \\
\text { methods? }\end{array}$ & $\begin{array}{l}\text { The purpose of cold test activities before operator training } \\
\text { (Sect. 4.6) is to establish the system's ability to operate } \\
\text { properly and to meet all design objectives. To document } \\
\text { this, checklists are being used. There are no checklists } \\
\text { associated with operator training. The purpose of operator } \\
\text { training is to familiarize and train operators with the system } \\
\text { and to evaluate system performance over its full range of } \\
\text { flows, pressure, and nozzle sizes. The number of tests } \\
\text { performed will be determined in the field based on sluicer } \\
\text { performance. Each combination of flow, pressure, and } \\
\text { nozzle size will be tested by the method in Sect. } 4.6 .5 \text {. The } \\
\text { most efficient method will be the combination of flow, } \\
\text { pressure, and nozzle size that provides adequate mixing } \\
\text { and complete sludge resuspension at the lowest pressure. } \\
\text { Efficiency will be determined by camera inspections of the } \\
\text { tanks after completion of sluicing. }\end{array}$ \\
\hline 8. & Page 4-36, §4.6.1, Step 2 & Is there some method to measure how much waste is left? & Liquid volume can be quantified, but solids volume cannot. \\
\hline 9. & Page $4-37, \S 4.6 .2$, Step 3 & $\begin{array}{l}\text { a) Specify specifically where "high differential pressure" is to be } \\
\text { observed. } \\
\text { b) How does one determine which work instruction is } \\
\text { appropriate? Isn't the correct response to the condition to go } \\
\text { thru the three work instructions in sequence. At what point } \\
\text { does one switch to the other strainer? }\end{array}$ & $\begin{array}{l}\text { a) Differential pressure is calculated from PI330 and } \\
\text { PI663. } \\
\text { b) This test has been separated into three tests to simulate } \\
\text { the different occurrences for each response. }\end{array}$ \\
\hline 10. & Page $4-37, \S 4.6 .3$ & $\begin{array}{l}\text { Shouldn't this state that the operators with the aid of others will } \\
\text { practice ... }\end{array}$ & Will be changed to read "operators and crane operator." \\
\hline 11. & Appendix A & Checklist 4.6 is missing. & There are no checklists associated with operator training. \\
\hline
\end{tabular}




\begin{tabular}{|c|c|c|c|}
\hline \multicolumn{4}{|c|}{$\begin{array}{l}\text { RESPONSES TO COMMENTS ON THE COLD TEST PLAN FOR } \\
\text { THE OLD HYDROFRACTURE FACILITY TANK CONTENTS REMOVAL PROJECT AT } \\
\text { THE OAK RIDGE NATIONAL LABORATORY, OAK RIDGE, TENNESSEE }\end{array}$} \\
\hline $\begin{array}{l}\text { Item } \\
\text { No. }\end{array}$ & $\begin{array}{l}\text { Page, Paragraph, and } \\
\text { Line }\end{array}$ & Comment & Resolution \\
\hline 12. & $\begin{array}{l}\text { Appendix B, Work } \\
\text { Instruction } 1 \text {, Steps } 9,10, \\
\text { and } 11\end{array}$ & $\begin{array}{l}\text { a) How is accuracy determined? Seems to imply some kind of } \\
\text { measurement. } \\
\text { b) Steps } 13 \text { and } 14 \text { are not clear to me. } \\
\text { c) Generally, what data is collected automatically and manually? } \\
\text { d) What video taping is required? } \\
\text { e) Step } 34-\text { open or close? }\end{array}$ & $\begin{array}{l}\text { a) The system must be "calibrated" after each tank } \\
\text { installation so that it roughly lines with the tank. } \\
\text { Calibration and accuracy are verified with observations } \\
\text { through the in-tank camera. } \\
\text { b) These steps allow the operator to know when the sluicer } \\
\text { is aimed at these items; thus, he can avoid hitting the } \\
\text { camera and can clear the pump intake if needed. These } \\
\text { steps have been rewritten to clarify their purpose. } \\
\text { c) See S.M. Babcock specific comment \#3. } \\
\text { d) Videotaping is not required. However, videotaping will } \\
\text { be used as a training aid and to help with work permit } \\
\text { applications. } \\
\text { e) "Open." Comment incorporated. }\end{array}$ \\
\hline 13. & $\begin{array}{l}\text { Appendix B, Work } \\
\text { Instruction 6, Step I }\end{array}$ & Should it have (VLV240-2)? & Yes. Comment incorporated. \\
\hline 14. & $\begin{array}{l}\text { Appendix B, Work } \\
\text { Instruction 8, Step } 1\end{array}$ & $\begin{array}{l}\text { a) Where is the "automatic shutdown" described? } \\
\text { b) Should the methodology for determining the cause of an } \\
\text { automatic shutdown be described? }\end{array}$ & $\begin{array}{l}\text { a) Automatic shutdown is a sequential function of the PLC } \\
\text { program. This sequence is more clearly described in } \\
\text { the operating plan. } \\
\text { b) An alarm message on the PLC will tell the operator the } \\
\text { cause. }\end{array}$ \\
\hline 15. & $\begin{array}{l}\text { Appendix B, Work } \\
\text { Instruction } 8 \text {, Step } 4\end{array}$ & Why? & CDM Federal considers this to be a better standby mode. \\
\hline 16. & $\begin{array}{l}\text { Appendix B, Work } \\
\text { Instruction } 8 \text {, Step } 5\end{array}$ & $\begin{array}{l}\text { Where is the line flushing sequence specified? Shouldn't it be } \\
\text { referenced here? }\end{array}$ & $\begin{array}{l}\text { A new work instruction (\#14) has been added for line } \\
\text { flushing. }\end{array}$ \\
\hline
\end{tabular}




\begin{tabular}{|c|c|c|c|}
\hline \multicolumn{4}{|c|}{$\begin{array}{l}\text { RESPONSES TO COMMENTS ON THE COLD TEST PLAN FOR } \\
\text { THE OLD HYDROFRACTURE FACILITY TANK CONTENTS REMOVAL PROJECT AT } \\
\text { THE OAK RIDGE NATIONAL LABORATORY, OAK RIDGE, TENNESSEE }\end{array}$} \\
\hline $\begin{array}{l}\text { Item } \\
\text { No. }\end{array}$ & $\begin{array}{l}\text { Page, Paragraph, and } \\
\text { Line }\end{array}$ & Comment & Resolution \\
\hline 17. & $\begin{array}{l}\text { Appendix B, Work } \\
\text { Instruction } 9\end{array}$ & Similar comments to items 14 and 15 above. & See responses to 14 and 15. \\
\hline 18. & $\begin{array}{l}\text { Appendix B, Work } \\
\text { Instruction 10, Step } 11\end{array}$ & Shouldn't specific equipment and valves be specified? & $\begin{array}{l}\text { This is a generic instruction. Valves/equipment may differ, } \\
\text { especially on first tank placement. }\end{array}$ \\
\hline 19. & $\begin{array}{l}\text { Appendix B, Work } \\
\text { Instruction } 14\end{array}$ & Missing & $\begin{array}{l}\text { The decision was made not to develop this work instruction } \\
\text { since dismantlement is a one-time event. The reference } \\
\text { was inadvertently not removed. }\end{array}$ \\
\hline \multicolumn{4}{|c|}{ Reviewer: M. W. Alexander } \\
\hline \multicolumn{4}{|c|}{ Specific Comments } \\
\hline 1. & Page 2-7, Table 2-1 & $\begin{array}{l}\text { Sluicer pump skid breaker trip point shown as } 350 \text { amps. } \\
\text { Figure } 2.5 \text { indicates } 400 \text { amps. }\end{array}$ & $\begin{array}{l}400 \text { amps is the breaker frame size. } 300 \text { is the trip point } \\
\text { setting. }\end{array}$ \\
\hline 2. & Page $3-1, \S 3.1 .1$ & $\begin{array}{l}\text { Reference to the PNNL } 100 \% \text { Design Overview should be } 90 \% \\
\text { Design Overview. }\end{array}$ & Comment incorporated. \\
\hline 3. & Page 4-11 & Checklist 4.2.5.48 missing. & Checklist added. \\
\hline \multicolumn{4}{|c|}{ Reviewer: G. F. Boris } \\
\hline \multicolumn{4}{|c|}{ General Comment } \\
\hline 1. & $\$ 4$, General & Leak test must be conducted the same as would be at the OHF site. & $\begin{array}{l}\text { The leak test has been rewritten to simulate conditions at } \\
\text { OHF. }\end{array}$ \\
\hline \multicolumn{4}{|c|}{ Specific Comments } \\
\hline 1. & Page 4-2, Figure 4.1 & Correct spelling of "mechanical." & Comment incorporated. \\
\hline 2. & Page 4-3, Step 10 & $\begin{array}{l}\text { MOV455 was never opened in the steps above this one, how do } \\
\text { you close it? }\end{array}$ & $\begin{array}{l}\text { The leak test has been completely rewritten, making the } \\
\text { comment no longer applicable. }\end{array}$ \\
\hline
\end{tabular}




\begin{tabular}{|c|c|c|c|}
\hline \multicolumn{4}{|c|}{$\begin{array}{l}\text { RESPONSES TO COMMENTS ON THE COLD TEST PLAN FOR } \\
\text { THE OLD HYDROFRACTURE FACILITY TANK CONTENTS REMOVAL PROJECT AT } \\
\text { THE OAK RIDGE NATIONAL LABORATORY, OAK RIDGE, TENNESSEE }\end{array}$} \\
\hline $\begin{array}{l}\text { Item } \\
\text { No. }\end{array}$ & $\begin{array}{l}\text { Page, Paragraph, and } \\
\text { Line }\end{array}$ & Comment & Resolution \\
\hline 3. & Page 4-3, Steps 13-16 & $\begin{array}{l}\text { It looks like you are setting up to run HPP320-1 in Steps } 13 \text { and } \\
14 \text {, but then you turn on HPP320-2. I'm not sure why you are } \\
\text { doing this. }\end{array}$ & $\begin{array}{l}\text { The leak test has been completely rewritten, making the } \\
\text { comment no longer applicable. }\end{array}$ \\
\hline 4. & Page 4-3, Step 17 & $\begin{array}{l}\text { This step says to run the pump for } 30 \text { seconds. Do you then shut } \\
\text { it off or is this just a } 30 \text {-second wait until you go to step } 18 ?\end{array}$ & $\begin{array}{l}\text { The leak test has been completely rewritten, making the } \\
\text { comment no longer applicable. }\end{array}$ \\
\hline 5. & Page 4-3, Step 20 & I couldn $t$ find a valve labelled as MOV $320-1$ & $\begin{array}{l}\text { The leak test has been completely rewritten, making the } \\
\text { comment no longer applicable. }\end{array}$ \\
\hline 6. & Page 4-3, Step 27 & $\begin{array}{l}\text { If HPP } 320-1 \text { is still running, wouldn't the } 75 \text { psi actually be } \\
215 \text { psi? }\end{array}$ & $\begin{array}{l}\text { The leak test has been completely rewritten, making the } \\
\text { comment no longer applicable. }\end{array}$ \\
\hline 7. & Page 4-4, Step 33 & $\begin{array}{l}\text { This implies that IIPP320-1 is still running . . see comments } 4 \\
\text { and } 6\end{array}$ & $\begin{array}{l}\text { The leak test has been completely rewritten, making the } \\
\text { comment no longer applicable. }\end{array}$ \\
\hline 8. & Page 4-4, Step 34 & $\begin{array}{l}\text { I'm not sure how you intend to leak test this section since it looks } \\
\text { like MOV } 370-1 \text { and }-2 \text { haven't been opened yet. }\end{array}$ & $\begin{array}{l}\text { The leak test has been completely rewritten, making the } \\
\text { comment no longer applicable. }\end{array}$ \\
\hline 9. & Page 4-4, Step 49 & $\begin{array}{l}\text { I think you should tell somewhere how to "shut down the system." } \\
\text { This should include shutting off the pumps, closing all valves, etc. }\end{array}$ & $\begin{array}{l}\text { The leak test has been completely rewritten, making the } \\
\text { comment no longer applicable. }\end{array}$ \\
\hline 10. & Page 4-26, $\S 4.4 .2 .3$ & $\begin{array}{l}\text { Are these still rupture disks? There was some discussion when we } \\
\text { looked at the pump PNNL is providing that these might need to be } \\
\text { changed to pressure relief valves. }\end{array}$ & Rupture disks have been installed. \\
\hline 11. & $\begin{array}{l}\text { Appendix B, Work } \\
\text { Instruction } 4\end{array}$ & Title on page 1 of 2 doesn't agree with that on page 2 of 2 . & Page 1 is correct. Page 2 has been changed. \\
\hline 12. & $\begin{array}{l}\text { Appendix B, Work } \\
\text { Instruction } 10\end{array}$ & Need to start the process water pump before you rinse the pipe out. & The process water pump will not be used during cold test. \\
\hline 13. & $\begin{array}{l}\text { Appendix B, Work } \\
\text { Instruction 10, Step } 24\end{array}$ & Correct spelling of "plate." & Comment incorporated. \\
\hline
\end{tabular}




\begin{tabular}{|c|c|c|c|}
\hline \multicolumn{4}{|c|}{$\begin{array}{l}\text { RESPONSES TO COMMENTS ON THE COLD TEST PLAN FOR } \\
\text { THE OLD HYDROFRACTURE FACILITY TANK CONTENTS REMOVAL PROJECT AT } \\
\text { THE OAK RIDGE NATIONAL LABORATORY, OAK RIDGE, TENNESSEE }\end{array}$} \\
\hline $\begin{array}{l}\text { Item } \\
\text { No. }\end{array}$ & $\begin{array}{l}\text { Page, Paragraph, and } \\
\text { Line }\end{array}$ & Comment & Resolution \\
\hline \multicolumn{4}{|c|}{ Reviewers: J. R. Barnett, T. L. Collins, C. H. Scott, and H. R. Yook } \\
\hline \multicolumn{4}{|c|}{ Specific Comments } \\
\hline 1. & $\begin{array}{l}\text { Page } 2-7, \S 2.4 \text { and } \\
\text { Page 6-1, } 6.1\end{array}$ & $\begin{array}{l}\text { Both of these locations indicate that the RPSD will have } \\
\text { responsibility for management of wastes generated during the cold } \\
\text { test. The Memorandum of Understanding between the OHF } \\
\text { Project and the RPSD does not include any RPSD responsibility } \\
\text { for waste management. This issue requires resolution. }\end{array}$ & $\begin{array}{l}\text { It is CDM Federal's understanding that Energy Systems } \\
\text { and RPSD have now resolved this comment, and RPSD } \\
\text { will manage the cold test wastes. }\end{array}$ \\
\hline 2. & Page $3-3, \S 3.1 .3$ & $\begin{array}{l}\text { The first paragraph mentions "... the radioactive nature of } \\
\text { materials at the OHF ..." and creates the impression that the } \\
\text { instrumentation and controls system will be tested under } \\
\text { radioactive conditions. A sentence should be added stating, } \\
\text { "These systems will be tested under non-radioactive conditions in } \\
\text { the cold test." }\end{array}$ & Comment incorporated. \\
\hline 3. & Page $5-1, \S 5$ & $\begin{array}{l}\text { This should be rewritten as follows to more clearly define these } \\
\text { responsibilities: "Robotics personnel and the ORNL Safety and } \\
\text { Health Environmental Support Team (SHEST) will provjde } \\
\text { environment, safety and health (ES\&H) oversight during the cold } \\
\text { test and will prepare the facility-related ES\&H documentation } \\
\text { based on information provided by CDM Federal regarding the } \\
\text { system operation and the materials to be used in the cold test. The } \\
\text { OHF Project and CDM Federal will be responsible for ES\&H for } \\
\text { all operations associated with the cold test. A Site Safety and } \\
\text { Health Officer will be present to monitor worker safety during all } \\
\text { active phases of the cold test." }\end{array}$ & $\begin{array}{l}\text { After discussion with RPSD, it was determined that RPSD } \\
\text { will provide ES\&H during all operations at the cold test } \\
\text { site (including setup, conduct of cold test, and } \\
\text { disassembly). CDM Federal will not provide an ES\&H } \\
\text { official for the cold test activities. }\end{array}$ \\
\hline
\end{tabular}




\begin{tabular}{|c|c|c|c|}
\hline \multicolumn{4}{|c|}{$\begin{array}{l}\text { RESPONSES TO COMMENTS ON THE COLD TEST PLAN FOR } \\
\text { THE OLD HYDROFRACTURE FACILITY TANK CONTENTS REMOVAL PROJECT AT } \\
\text { THE OAK RIDGE NATIONAL LABORATORY, OAK RIDGE, TENNESSEE }\end{array}$} \\
\hline $\begin{array}{l}\text { Item } \\
\text { No. }\end{array}$ & $\begin{array}{l}\text { Page, Paragraph, and } \\
\text { Line }\end{array}$ & Comment & Resolution \\
\hline \multicolumn{4}{|c|}{ Reviewer: L. S. Hawk } \\
\hline \multicolumn{4}{|c|}{ General Comments } \\
\hline$\overline{1 .}$ & General & $\begin{array}{l}\text { The cold test at TTCTF should begin with process water filling the } \\
\text { system from Robotic process water to determine how we will fill } \\
\text { the system at OHF with ALL valves to the tanks OFF. Leak check } \\
\text { the system and remove the air the same way that we will at OHF } \\
\text { from DRY startup. "Process water test, Fig. 4.2" all the way using } \\
\text { process water to test HPP-1\&2, to pressure test piping, certify } \\
\text { rupture disk, etc. After all tests have been conducted using clean } \\
\text { water, then add the clay. }\end{array}$ & $\begin{array}{l}\text { CDM Federal wishes to set up one of the tanks to have a } \\
\text { sludge layer like OHF. Because of the uncertainty in } \\
\text { settling time and to prove the ability to "decant" } \\
\text { supernatant, we prefer to have clay in the sluice tank when } \\
\text { we arrive. }\end{array}$ \\
\hline 2. & General & $\begin{array}{l}\text { A positive FOOL PROOF method SHALL be in place to } \\
\text { determine if pumps are rotating properly and if valves are properly } \\
\text { oriented open or closed. Note: perhaps an additional step-initial } \\
\text { startup or something similar-would solve the process/supernatant } \\
\text { problem for initial charging of the system. }\end{array}$ & $\begin{array}{l}\text { This will be informally completed during factory testing } \\
\text { and site setup. This will be formally completed and } \\
\text { documented during the I\&C test as currently planned. }\end{array}$ \\
\hline 3. & $\begin{array}{l}\$ 4.2 .5 \text {, "Testing } \\
\text { Instructions", General }\end{array}$ & $\begin{array}{l}\text { Note, field verification of all pump rotations and valve } \\
\text { open/closure shall be conducted at CTF and OHF prior to } \\
\text { operation. }\end{array}$ & $\begin{array}{l}\text { The I\&C test used to accomplish this at the cold test will be } \\
\text { conducted at OHF prior to startup of operations. }\end{array}$ \\
\hline 4. & $\begin{array}{l}\$ 4.2 .5, \text { "Testing } \\
\text { Instructions", General }\end{array}$ & $\begin{array}{l}\text { Does actuation of "E" kill change status output and/or allow power } \\
\text { back on without process disruptions. }\end{array}$ & $\begin{array}{l}\text { E-Kill triggers full shutdown of pumping systems and all } \\
\text { valves close. Restart from E-Kill can be accomplished } \\
\text { from the PLC. }\end{array}$ \\
\hline \multicolumn{4}{|c|}{ Specific Comments } \\
\hline 1. & Page $1-1, \S 1, \rrbracket 1$ & $\begin{array}{l}\text { The Robotics and Process Systems Complex is referred to by } \\
\text { Robotics as the Tank Technology Cold Test Facility (TTCTF) } \\
\text { when asked to define their facility. }\end{array}$ & Comment incorporated. \\
\hline 2. & \begin{tabular}{|l} 
Page $1-1, \S 1.1$ and \\
Page 4-35, \&4.6
\end{tabular} & Training matrix (Who $\mid$ What $\mid$ How $\mid$ When $\mid$ Certification)? & $\begin{array}{l}\text { A table with the required training information will be } \\
\text { incorporated. }\end{array}$ \\
\hline 3. & Page 3-3, 1st Bullet & Change "tank drop legs" to "tank drip legs." & "Drop legs" is the correct term. \\
\hline
\end{tabular}




\begin{tabular}{|c|c|c|c|}
\hline \multicolumn{4}{|c|}{$\begin{array}{l}\text { RESPONSES TO COMMENTS ON THE COLD TEST PLAN FOR } \\
\text { THE OLD HYDROFRACTURE FACILITY TANK CONTENTS REMOVAL PROJECT AT } \\
\text { THE OAK RIDGE NATIONAL LABORATORY, OAK RIDGE, TENNESSEE }\end{array}$} \\
\hline $\begin{array}{l}\text { Item } \\
\text { No. }\end{array}$ & $\begin{array}{l}\text { Page, Paragraph, and } \\
\text { Line }\end{array}$ & Comment & Resolution \\
\hline 4. & Page 4-1, § 4.1, 71 & $\begin{array}{l}\text { Change the second sentence to read, "The test fluid will be clean } \\
\text { process water." Also, the following sentence should be added to } \\
\text { the end of the paragraph: "Note: All piping shall be complete and } \\
\text { pressure testing will be conducted up to the last valve in the } \\
\text { system." }\end{array}$ & $\begin{array}{l}\text { a) Comment incorporated. } \\
\text { b) Comment incorporated. After discussing the leak test, } \\
\text { CDM Federal has decided to blind flange certain pipes } \\
\text { for the leak test. }\end{array}$ \\
\hline 5. & Page 4-I, § 4.1, "Note" & $\begin{array}{l}\text { How do you get the system full of process water to vent the air? } \\
\text { Air relief from dead end line (top of strainers)? }\end{array}$ & $\begin{array}{l}\text { The leak test has been rewritten. The new procedure } \\
\text { includes line bleeding. }\end{array}$ \\
\hline 6. & $\begin{array}{l}\text { Page } 4-1, \$ 4.1 \text {. "Testing } \\
\text { Instructions" Item \#1 }\end{array}$ & Change "Close all valves." to read, "Open appropriate valves." & $\begin{array}{l}\text { The leak test has been rewritten, making the comment no } \\
\text { longer applicable. }\end{array}$ \\
\hline 7. & $\begin{array}{l}\text { Page 4-1, § 4.1, "Testing } \\
\text { Instructions" Item \#3 }\end{array}$ & No water! MOV235 must be open. & $\begin{array}{l}\text { The leak test has been rewritten, making the comment no } \\
\text { longer applicable. }\end{array}$ \\
\hline 8. & $\begin{array}{l}\text { Page } 4-1, \S 4.1, \text { "Testing } \\
\text { Instructions" Item \#4 }\end{array}$ & Clarify to read that sludge contaminated water is being pumped. & $\begin{array}{l}\text { The leak test has been rewritten, making the comment no } \\
\text { longer applicable. }\end{array}$ \\
\hline 9. & $\begin{array}{l}\text { Page } 4-3, \S 4.1 \text {, “Testing } \\
\text { Instructions" Item \#7 }\end{array}$ & Supply contaminated! & $\begin{array}{l}\text { The leak test has been rewritten, making the comment no } \\
\text { longer applicable. }\end{array}$ \\
\hline 10. & $\begin{array}{l}\text { Page } 4-3, \S 4.1 \text {, "Testing } \\
\text { Instructions" Item } \# 10\end{array}$ & MOV410-2? & $\begin{array}{l}\text { The leak test has been rewritten, making the comment no } \\
\text { longer applicable. }\end{array}$ \\
\hline 11. & $\begin{array}{l}\text { Page } 4-4, \S 4.1, \text { "Testing } \\
\text { Instructions" Item \#36 }\end{array}$ & Change to read, "Remotely close all valves from PLC. & $\begin{array}{l}\text { The leak test has been rewritten, making the comment no } \\
\text { longer applicable. }\end{array}$ \\
\hline 12. & $\begin{array}{l}\text { Page 4-7, } \$ 4.2 .4, \text { "Testing } \\
\text { Instructions" Item \#1 }\end{array}$ & $\begin{array}{l}\text { Add to the end of this statement, "... and verify that all } I / O \\
\text { readings are the same, i.e., phased power from primary to auxiliary } \\
\text { is the same." }\end{array}$ & Comment incorporated. \\
\hline 13 & $\begin{array}{l}\text { Page } 4-9, \S 4.2 .5 \text {, “Testing } \\
\text { Instructions" Item \#6 }\end{array}$ & $\begin{array}{l}\text { Caution-Lens must be allowed to cool for } 5 \text { minutes before } \\
\text { flushing with water. }\end{array}$ & $\begin{array}{l}\text { Comment incorporated. Additionally, CDM Federal is } \\
\text { talking with GAAT personnel about heat on the cameras. }\end{array}$ \\
\hline 14. & Page $4-12, \S 4.3 .1$ & $\begin{array}{l}\text { Add a sentence to the end of this section that states "the drain } \\
\text { valve. on the receiver tank bottom is to be drained after each } \\
\text { operation to prevent ice formation during cold weather." }\end{array}$ & $\begin{array}{l}\text { The air receiver tank is equipped with an automatic drain } \\
\text { valve that automatically drains the tank of moisture as soon } \\
\text { as it forms. }\end{array}$ \\
\hline
\end{tabular}




\begin{tabular}{||c|l|l|l||}
\hline \multicolumn{3}{|c|}{ THE OLD HYDROFRACTURE FACILITY TANK CONTENTS REMOVAL PROJECT AT } \\
THE OAK RIDGE NATIONAL LABORATORY, OAK RIDGE, TENNESSEE
\end{tabular}




\begin{tabular}{|c|c|c|c|}
\hline \multicolumn{4}{|c|}{$\begin{array}{l}\text { RESPONSES TO COMMENTS ON THE COLD TEST PLAN FOR } \\
\text { THE OLD HYDOFRACTURE FACILITY TANK CONTENTS REMOVAL PROJECT AT } \\
\text { THE OAK RIDGE NATIONAL LABORATORY, OAK RIDGE, TENNESSEE }\end{array}$} \\
\hline $\begin{array}{l}\text { Item } \\
\text { No. }\end{array}$ & $\begin{array}{l}\text { Page, Paragraph, and } \\
\text { Line }\end{array}$ & Comment & Resolution \\
\hline 22. & $\begin{array}{l}\text { Appendix A, } \\
\text { Checklist 4.2.3 }\end{array}$ & $\begin{array}{l}\text { Remember three phase power can cause extensive problems if } \\
\text { hooked out of the desired phasing! Criteria: Loop } 205 \text { (Pump } \\
\text { Running)-rotation?; Loop 305-how can you tell if it is full open } \\
\text { or full closed?; Loop 400 (Mixer Running)-correct direction } \\
\text { looking down?; Loop 455-is detection physical if MOV455 full } \\
\text { open or full closed?; Loop } 495 \text { (Pressure Pump Running)-correct } \\
\text { rotation? }\end{array}$ & $\begin{array}{l}\text { Noted, CDM Federal has extensive experience with } \\
\text { 3-phase power and the challenges it can present. CDM } \\
\text { Federal has planned testing of each and every control loop } \\
\text { to verify proper equipment operation, communication, and } \\
\text { PLC response. The checklist referred to }(4.2 .3) \text { is the } 1 / O \\
\text { checklist which serves to verify communication between } \\
\text { the equipment and the PLC. Proper operation of the } \\
\text { equipment is verified during the factory testing and during } \\
\text { the extensive } 1 \& C \text { testing discussed in Sect. } 4.2 \text {. In the } \\
\text { cases of loops } 205 \text { and } 400 \text {, these pieces of equipment will } \\
\text { not be present at the cold test. They will be factory tested } \\
\text { and proper operation verified during I\&C testing at the } \\
\text { OHF site. In the cases of loops } 305 \text { and } 455 \text {, proper valve } \\
\text { operation is verified during the factory test, during the I\&C } \\
\text { test at the cold test (checklists } 4.2 .5 .11 \text { and } 4.2 .5 .32) \text {, and } \\
\text { during the I\&C test at OHF. In the case of loop } 495 \text {, } \\
\text { proper pump rotation is verified during factory testing. }\end{array}$ \\
\hline 23. & $\begin{array}{l}\text { Appendix B, Work } \\
\text { Instruction } 1\end{array}$ & $\begin{array}{l}\text { Note: System SHALL be filled with clean process water for the } \\
\text { initial leak testing and problem resolution. The system would still } \\
\text { be nonradiologically contaminated at this point. }\end{array}$ & $\begin{array}{l}\text { This work instruction takes place after completion of } \\
\text { testing (see work instruction prerequisites). }\end{array}$ \\
\hline 24. & $\begin{array}{l}\text { Appendix B, Work } \\
\text { Instruction } 2\end{array}$ & $\begin{array}{l}\text { "Work Instructions" Item \#2: Note, the air receiver drain valve } \\
\text { must be closed. }\end{array}$ & Air receiver drain valve is automatic. \\
\hline 25. & $\begin{array}{l}\text { Appendix B, Work } \\
\text { Instruction } 6\end{array}$ & $\begin{array}{l}\text { a) Who's lockouttagout procedure to be used: ORNL/LMER, } \\
\text { ER-LMES, or CDM? } \\
\text { b) "Work Instructions" Item \#1: Remember to enable remote } \\
\text { operation of MOVs. Do not unbolt strainer unless you have } \\
\text { tested for residual air pressure up to latest operating pressure. } \\
\text { Special taping of bag around strainer body to trap the leaks and } \\
\text { divert the anticipated spray unless "pressure" has been vented. } \\
\text { Remember safety, lessons learned! }\end{array}$ & $\begin{array}{l}\text { a) Most likely, ER-LMES, but may use ORNL/LMER } \\
\text { depending on availability of training. } \\
\text { b) A pressure relief step has been added. }\end{array}$ \\
\hline
\end{tabular}




\begin{tabular}{|c|c|c|c|}
\hline \multicolumn{4}{|c|}{$\begin{array}{l}\text { RESPONSES TO COMMENTS ON THE COLD TEST PLAN FOR } \\
\text { THE OLD HYDROFRACTURE FACILITY TANK CONTENTS REMOVAL PROJECT AT } \\
\text { THE OAK RIDGE NATIONAL LABORATORY, OAK RIDGE, TENNESSEE }\end{array}$} \\
\hline $\begin{array}{l}\text { Item } \\
\text { No. }\end{array}$ & $\begin{array}{l}\text { Page, Paragraph, and } \\
\text { Line }\end{array}$ & Comment & Resolution \\
\hline $\begin{array}{c}25 . \\
\text { cont. }\end{array}$ & $\begin{array}{l}\text { Appendix B, Work } \\
\text { Instruction } 6 \\
\text { (cont.) }\end{array}$ & $\begin{array}{l}\text { c) "Work Instructions" Item \#4: Solid particles in strainer basket } \\
\text { opening and strainer is expected to be highly contaminated. } \\
\text { Lead shielding and steel containers or cask may be required. } \\
\text { Practice ALARA. }\end{array}$ & $\begin{array}{l}\text { Extensive consideration has been given to this. The } \\
\text { method will be further evaluated during the cold test. }\end{array}$ \\
\hline 26. & $\begin{array}{l}\text { Appendix } \mathrm{B}, \text { Work } \\
\text { Instruction } 8\end{array}$ & $\begin{array}{l}\text { "Work Instructions" Item \#I: Do we have this option at the skids } \\
\text { or a disconnect switch? }\end{array}$ & There is a main disconnect on each skid. \\
\hline 27. & $\begin{array}{l}\text { Appendix B. Work } \\
\text { Instruction } 9\end{array}$ & $\begin{array}{l}\text { "Work Instructions" Item \#4: Why would you not just "E" stop } \\
\text { system/skid and determine extent of leak without flushing } \\
\text { additional material through the leak? }\end{array}$ & $\begin{array}{l}\text { CDM Federal believes it is appropriate to get the waste } \\
\text { back into the tanks. However, it is a judgment call it } \\
\text { emergency-stop is needed (i.e., major rupture). }\end{array}$ \\
\hline 28. & $\begin{array}{l}\text { Appendix B, Work } \\
\text { Instruction } 10\end{array}$ & $\begin{array}{l}\text { a) "Work Instructions": Pump PWP205 required? No valve at } \\
\text { spray ring? } \\
\text { b) "Work Instructions" Item \#9: How measured? } \\
\text { c) "Work Instructions" Item \#11: Enumerate. } \\
\text { d) "Work Instructions" Item \#12: Bag hose ends? Elevate free } \\
\text { end to prevent drainage onto site? } \\
\text { e) "Work Instructions" Item } \# 24: \text { Change "plaste" to "plate." }\end{array}$ & $\begin{array}{l}\text { a) Pump PWP205 will not be used at the cold test. } \\
\text { b) By flowmeter FE210. } \\
\text { c) See response to S.M. Babcock specific comment \#18. } \\
\text { d) Disconnects are dry connectors. } \\
\text { e) Comment incorporated. }\end{array}$ \\
\hline 29. & $\begin{array}{l}\text { Appendix B, Work } \\
\text { Instruction } 13\end{array}$ & $\begin{array}{l}\text { a) Add the following: "Remove two flanges to gain full access to } \\
\text { rupture disk for reseating and proper installation. Do not pry } \\
\text { flanges apart to slip disk in resulting in damage or improper } \\
\text { seating. Note: The line may be full of hot (contaminated) } \\
\text { particles." } \\
\text { b) "Work Instructions" Item \#4: Convex/concaved? Add figure } \\
\text { if installed as below the rupture disk will fail at } 12-1500 \mathrm{lb} \text {, not } \\
275 \text {. }\end{array}$ & $\begin{array}{l}\text { a) The rupture disk specified is in a holder designed for } \\
\text { this type of replacement. Prying flanges is not needed. } \\
\text { b) The procedure is correct. Installing the disk backwards } \\
\text { will allow it to blow at a pressure less than the designed } \\
\text { pressure. The disks specified cannot be installed such } \\
\text { that they blow at a higher pressure than designed. }\end{array}$ \\
\hline 30. & Appendix C & $\begin{array}{l}\text { Confidential. Do not publish in open. Literature for rehearsal and } \\
\text { study. }\end{array}$ & Comment incorporated. \\
\hline
\end{tabular}




\section{Cold Test Plan for the Old Hydrofracture Facility Tank Contents Removal Project, Oak Ridge National Laboratory, Oak Ridge, Tennessee}

Date Issued-November 1997

Prepared by

CDM Federal Programs Corporation

Oak Ridge, Tennessee 37830

under subcontract 13B-99313C

Document Control No. 5151-015-FR-BBSP

Prepared for the

U.S. Department of Energy

Office of Environmental Management under budget and reporting code EW 20

Environmental Management Activities at the OAK RIDGE NATIONAL LABORATORY

Oak Ridge, Tennessee 37831

managed by

LOCKHEED MARTIN ENERGY SYSTEMS, INC.

for the

U.S. DEPARTMENT OF ENERGY

under contract DE-AC05-84OR21400 


\section{CONTENTS}

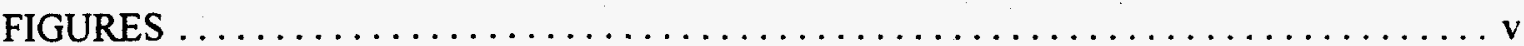

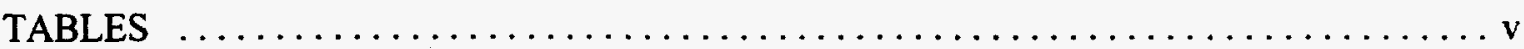

ABBREVIATIONS $\ldots \ldots \ldots \ldots \ldots \ldots \ldots \ldots \ldots \ldots \ldots \ldots \ldots \ldots \ldots \ldots \ldots \ldots \ldots \ldots$

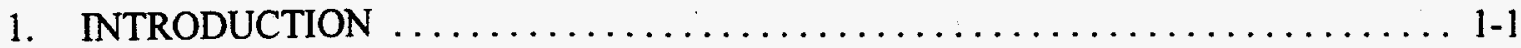

1.1 COLD TEST ACTIVITY $\ldots \ldots \ldots \ldots \ldots \ldots \ldots \ldots \ldots \ldots \ldots \ldots \ldots \ldots \ldots \ldots \ldots \ldots \ldots \ldots \ldots$

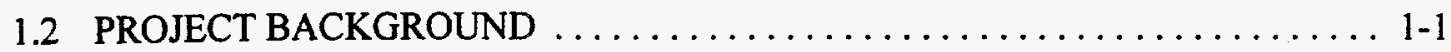

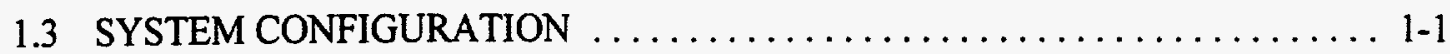

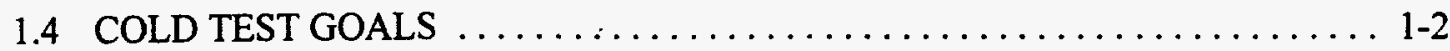

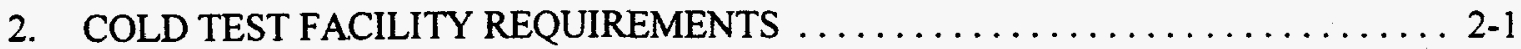

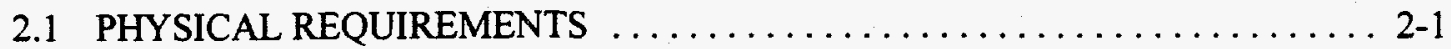

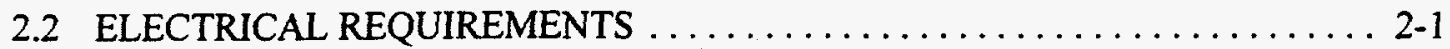

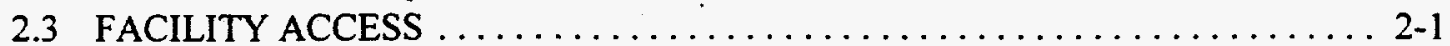

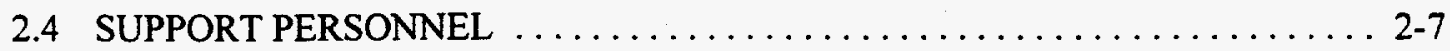

3. OHF COLD TEST SYSTEM CONFIGURATION $\ldots \ldots \ldots \ldots \ldots \ldots \ldots \ldots \ldots \ldots \ldots \ldots \ldots \ldots$

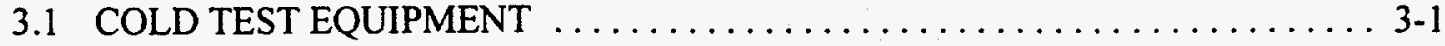

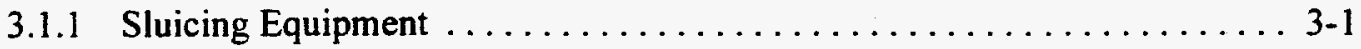

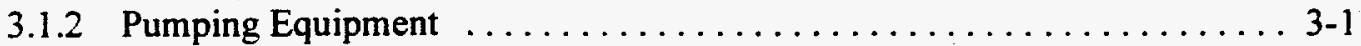

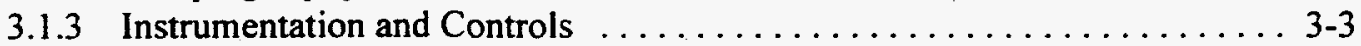

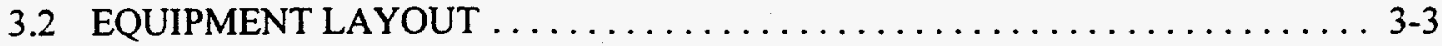

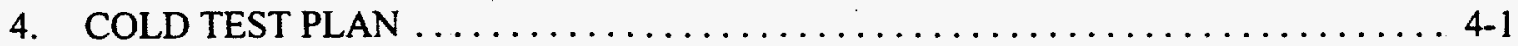

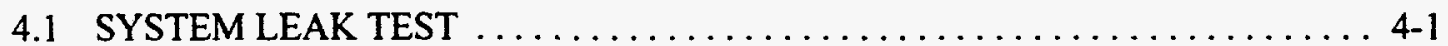

4.2 INSTRUMENTATION AND CONTROLS TEST $\ldots \ldots \ldots \ldots \ldots \ldots \ldots \ldots \ldots$

4.2.1 Field Instrumentation and Equipment Tagging Verification Test . . . . . . 4-6

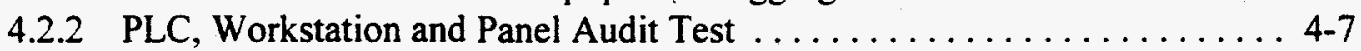

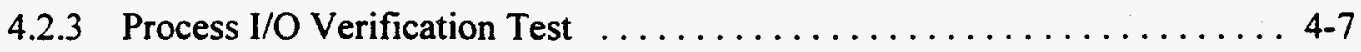

4.2.4 PLC, Workstation, and Panel Failure Test $\ldots \ldots \ldots \ldots \ldots \ldots \ldots \ldots . . \ldots \ldots$

4.2.5 Process Control Verification Test $\ldots \ldots \ldots \ldots \ldots \ldots \ldots \ldots \ldots \ldots \ldots . \ldots \ldots$

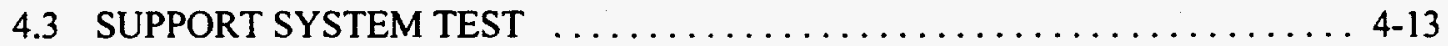

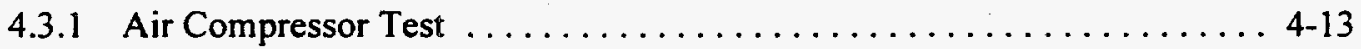

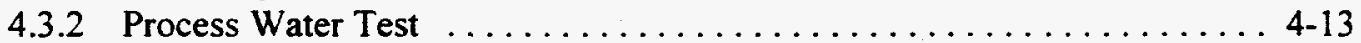

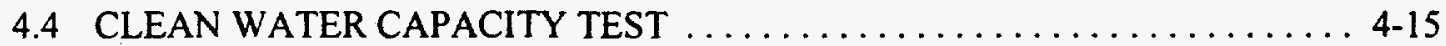

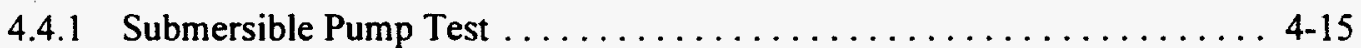

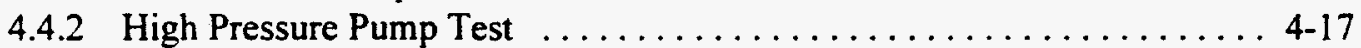

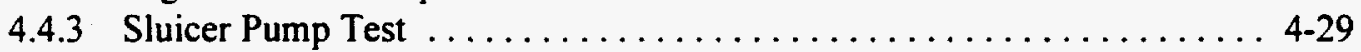

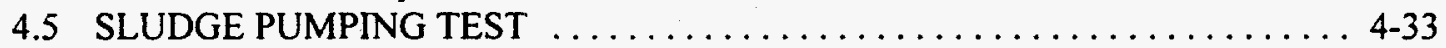

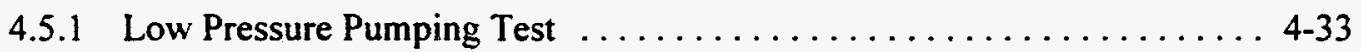

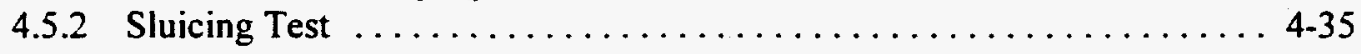

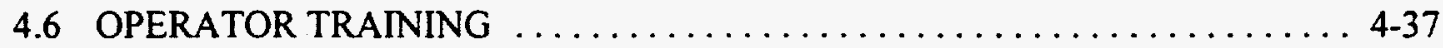

4.6.1 Routine Startup, Operation, and Shutdown ............... 4-37

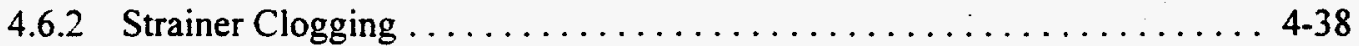




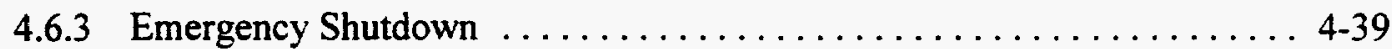

4.6 .4 Sluicer Movement $\ldots \ldots \ldots \ldots \ldots \ldots \ldots \ldots \ldots \ldots \ldots \ldots .4 \ldots \ldots \ldots$

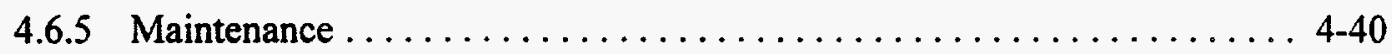

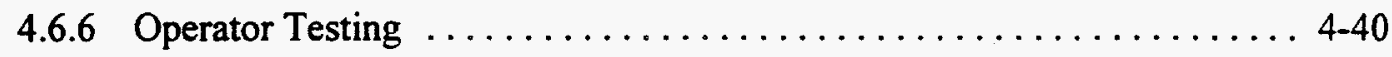

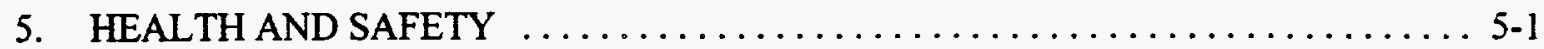

6. WASTE MANAGEMENT $\ldots \ldots \ldots \ldots \ldots \ldots \ldots \ldots \ldots \ldots \ldots \ldots \ldots \ldots \ldots \ldots \ldots$

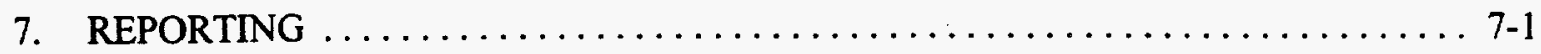

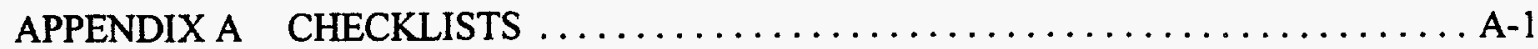

APPENDIX B WORK INSTRUCTIONS $\ldots \ldots \ldots \ldots \ldots \ldots \ldots \ldots \ldots \ldots \ldots \ldots \ldots$ 


\section{FIGURES}

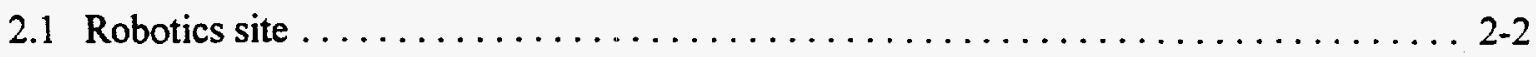

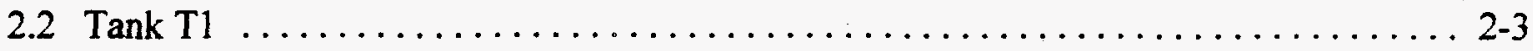

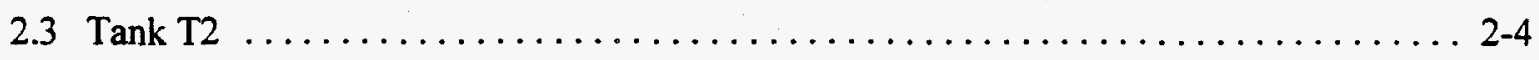

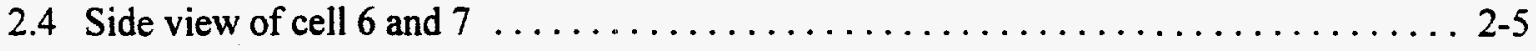

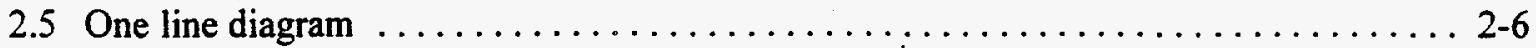

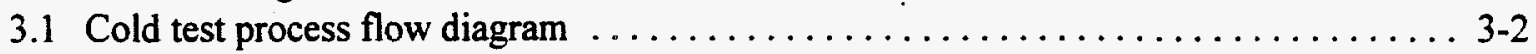

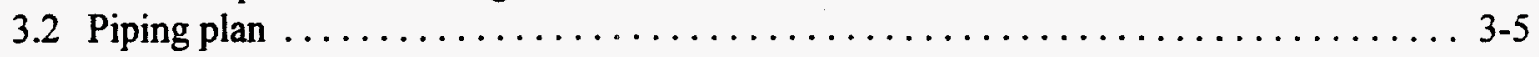

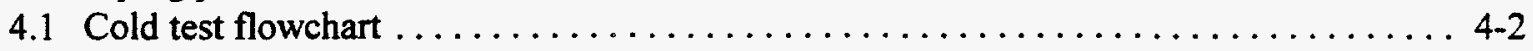

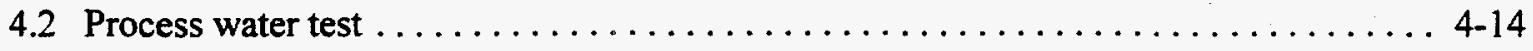

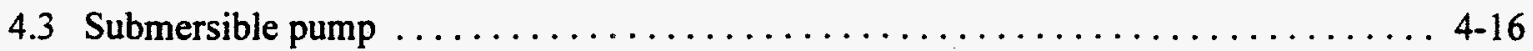

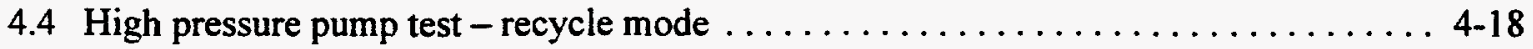

4.5 High pressure pump test - on-line strainer flushing mode $\ldots \ldots \ldots \ldots \ldots \ldots \ldots$ 4-19

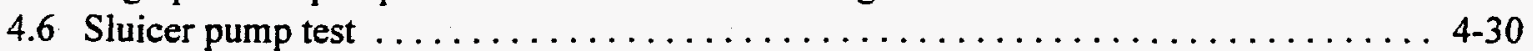

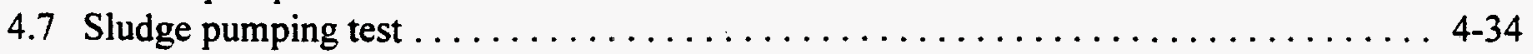

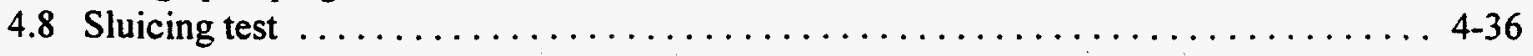

\section{TABLES}

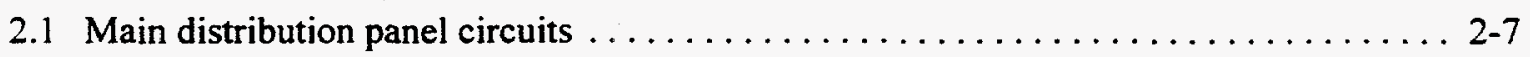

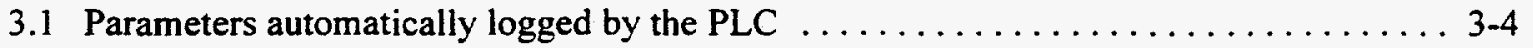


-

-

- 


\section{ABBREVIATIONS}

$\begin{array}{ll}\text { CDM Federal } & \text { CDM Federal Programs Corporation } \\ \text { DOE } & \text { U.S. Department of Energy } \\ \text { Energy Systems } & \text { Lockheed Martin Energy Systems, Inc. } \\ \text { HEPA } & \text { high-efficiency particulate air } \\ \text { I/O } & \text { input/output } \\ \text { I\&C } & \text { instrumentation and control } \\ \text { LMER } & \text { Lockheed Martin Energy Research Corp. } \\ \text { MVST } & \text { Melton Valley Storage Tanks } \\ \text { OHF } & \text { Old Hydrofracture Facility } \\ \text { ORNL } & \text { Oak Ridge National Laboratory } \\ \text { PLC } & \text { programmable logic controller } \\ \text { PNNL } & \text { Pacific Northwest National Laboratory } \\ \text { TTCTF } & \text { Tank Technology Cold Test Facility }\end{array}$




\section{INTRODUCTION}

This Old Hydrofracture Facility (OHF) Tanks Contents Removal Project Cold Test Plan describes the activities to be conducted during the cold test of the OHF sluicing and pumping system at the Tank Technology Cold Test Facility (TTCTF). The TTCTF is located at the Robotics and Process Systems Complex at the Oak Ridge National Laboratory (ORNL).

\subsection{COLD TEST ACTIVITY}

The cold test will demonstrate performance of the pumping and sluicing system, fine-tune operating instructions, and train the personnel in the actual work to be performed. After completion of the cold test a Technical Memorandum will be prepared documenting completion of the cold test, and the equipment will be relocated to the OHF site.

\subsection{PROJECT BACKGROUND}

In March 1997, Lockheed Martin Energy Systems, Inc. (Energy Systems) tasked CDM Federal Programs Corporation (CDM Federal) to prepare a configuration for a system to sluice the OHF tanks contents into a slurry of supernatant and sludge, then pump the slurry to the Melton Valley Storage Tanks (MVST) for disposal. The basis for this configuration was the Preliminary Engineering Report (Energy Systems 1996). In completing the system configuration some modifications were made from the Preliminary Engineering Report. These modifications were made to improve performance, efficiency, and cost of the system. In April 1997, CDM Federal issued the $100 \%$ Configuration for the sluicing and pumping system, and in June 1997 initiated the procurement for the equipment for the system. The system is currently being constructed and is scheduled for shipment to TTCTF in the fall of 1997.

A key component of the sluicing and pumping system, the Borehole Miner, is being provided by Pacific Northwest National Laboratory (PNNL). The Borehole Miner is an in-tank device designed to deliver a high-pressure jet spray via an extendible nozzle. The system being provided by PNNL includes the extendible nozzle, a high pressure pump (referred to as the sluicer pump), a hydraulic power unit, and associated controls. The Borehole Miner has been developed and configured in coordination with the CDM Federal sluicing and pumping system.

\subsection{SYSTEM CONFIGURATION}

The sluicing and pumping system consists of four main systems:

- $\quad$ Sluicing system (high-pressure spray nozzle),

- Pumping system (providing slurry circulation and to pump the slurry to MVST), 
- Ventilation system [providing negative pressure on the tanks and high-efficiency particulate air (HEPA) filtration), and

- Instrumentation and control (I\&C) system (providing remote monitoring and control of all systems).

During the cold test, all the main systems will be tested except the ventilation system, which will be limited to piping configuration testing. There is no operational or training value to testing the ventilation system at the cold test. The ventilation system will be thoroughly tested for operation and performance at the fabrication facility and at the OHF site before startup of sluicing operations.

\subsection{COLD TEST GOALS}

The cold test is being performed to meet the following goals:

1. evaluate the operational status of the full sluicing and pumping systems as well as individual components of the system,

2. train the field operators, and

3. demonstrate readiness of both the system and the crew to proceed to the OHF site and conduct the tanks contents removal action.

Chapter 4 of this plan defines a series of tests that will be performed to evaluate system and individual component readiness. Each test describes a sequence of activities and defines successful completion. If a test is not successfully completed, the project team will discuss test results and repairs/reconfigurations as needed. The test will be repeated until successful completion.

After the systems and individual components have been successfully tested, the operators will be trained to the various task instructions comprising the Operating Plan for the removal action. Crew members will be trained in the various activities of Borehole Miner operation and relocation between tanks, instrumentation and control operation, and system maintenance. Various emergency and system failure scenarios will be conducted to provide nonroutine training. After each test, the operators will be given a written examination to document successful test completion.

At completion of the cold test system evaluation and operator training, readiness to proceed to the OHF site will have been demonstrated. 


\section{COLD TEST FACILITY REQUIREMENTS}

The cold test will require modifications to the TTCTF, electrical power supply, a designated working area, and the support of TTCTF personnel.

\subsection{PHYSICAL REQUIREMENTS}

The cold test will be conducted in the area north of Building 7600 and east of Building 7604 at the TTCTF (Fig. 2.1). To approximate the conditions at the OHF, two steel tanks will be purchased and installed in cell 7 by Energy Systems and Lockheed Martin Energy Research Corp. (LMER). Tank 1 will simulate a tank being sluiced with an 18-in. riser and a 26-in. riser (Fig. 2.2). Tank 2 will simulate the recycle tank with two 26-in. risers (Fig. 2.3). After tank installation, wooden decking will be placed over the cells to provide support for the sluicer and to provide access to the risers. The tanks will be installed in the cell so that the risers extend $-1 \mathrm{ft}$ above the decking (Fig. 2.4).

The area immediately north of cell 7 will be available for placing large equipment such as the sluice pump skid, transfer pump skid, the air compressor skid, and the crane. Electronic equipment such as the visualization system, the programmable logic controller (PLC), and the sluicer control panel will be placed in Building 7604. A break area and small equipment staging/storage area will be located in the same room as the electronic equipment.

To simulate the waste, process water and kaolin clay will be added to the tanks by Energy Systems. Before cold testing, a kaolin clay/water slurry will be placed in tank $T 1$ and given enough time to separate into supernatant and sludge. Only water will be placed in tank T2.

A watertight roll-off bin will be placed northeast of the cells. This container will be used to practice the steps for transferring waste to the MVST.

\subsection{ELECTRICAL REQUIREMENTS}

The systems to be operated during the cold test will require 120 -volt and 480 -volt power. Existing circuits in Building 7604 will provide 120-volt power to the electronic equipment used to monitor and control the sluicing system. A one line diagram of the 480 -volt power requirements is presented in Fig. 2.5. To provide this power, existing power distribution panels at the TTCTF will be modified by Energy Systems and LMER to include the electrical breakers listed in Table 2.1.

\subsection{FACILITY ACCESS}

Normal work hours at the TTCTF are 7:00 a.m. to 5:00 p.m., Monday through Friday. The cold test is planned to be conducted during normal hours. Should circumstances require, special arrangements may be made to permit work outside these hours to maintain the project schedule. 


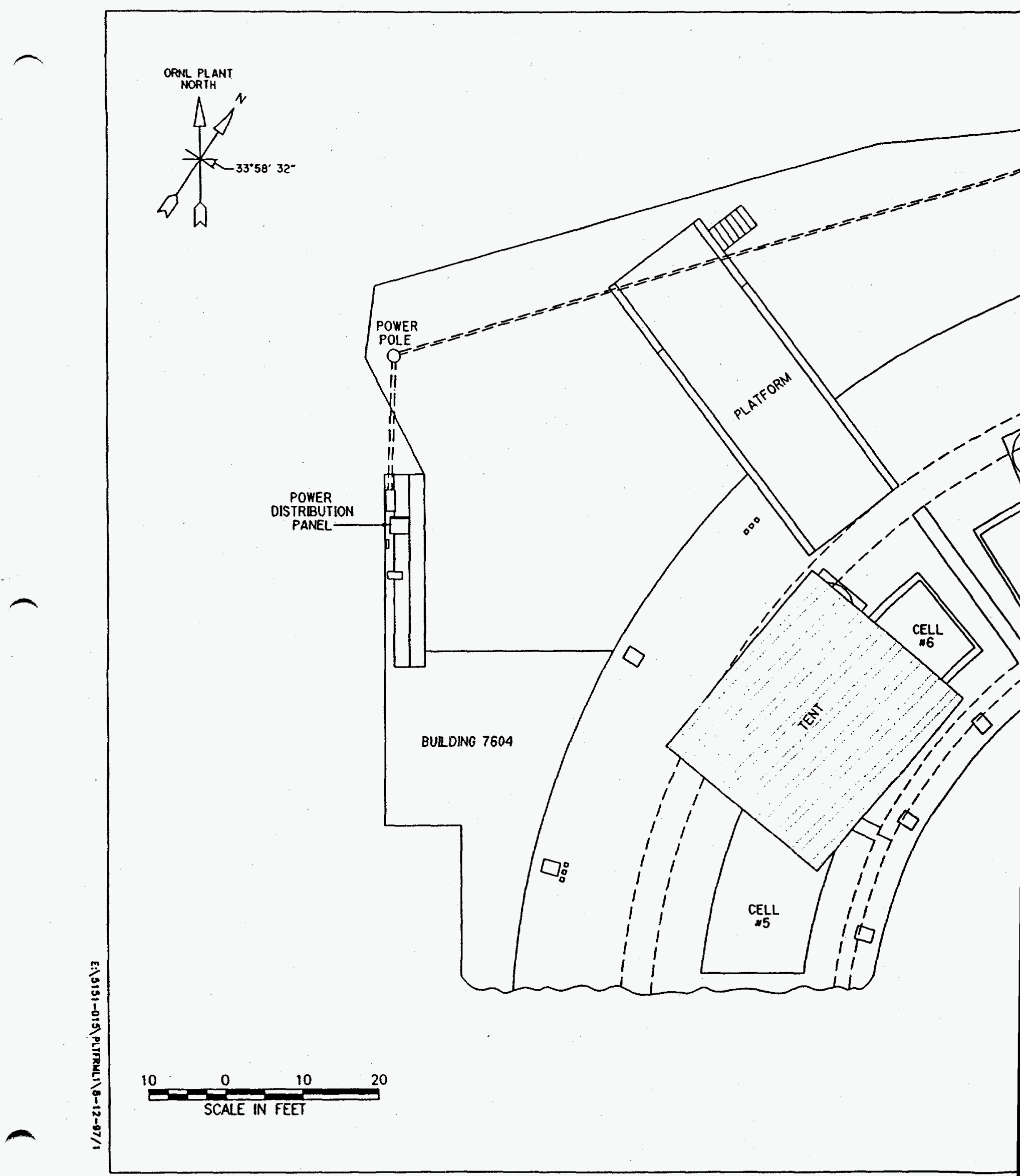

\section{CDII}

environmental engineers, scientists,

planners, \& management consultant: 

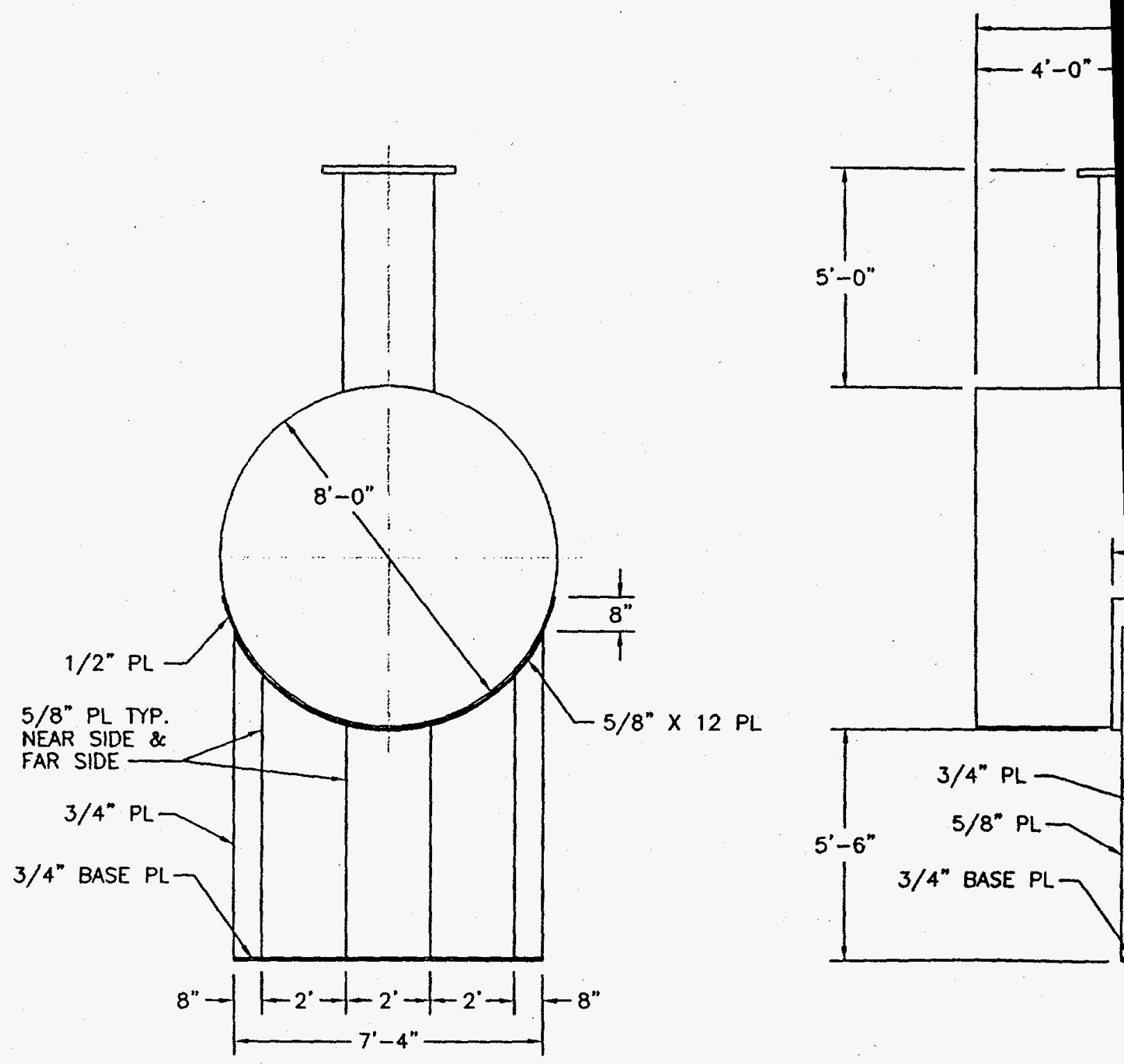

\section{SECTION}



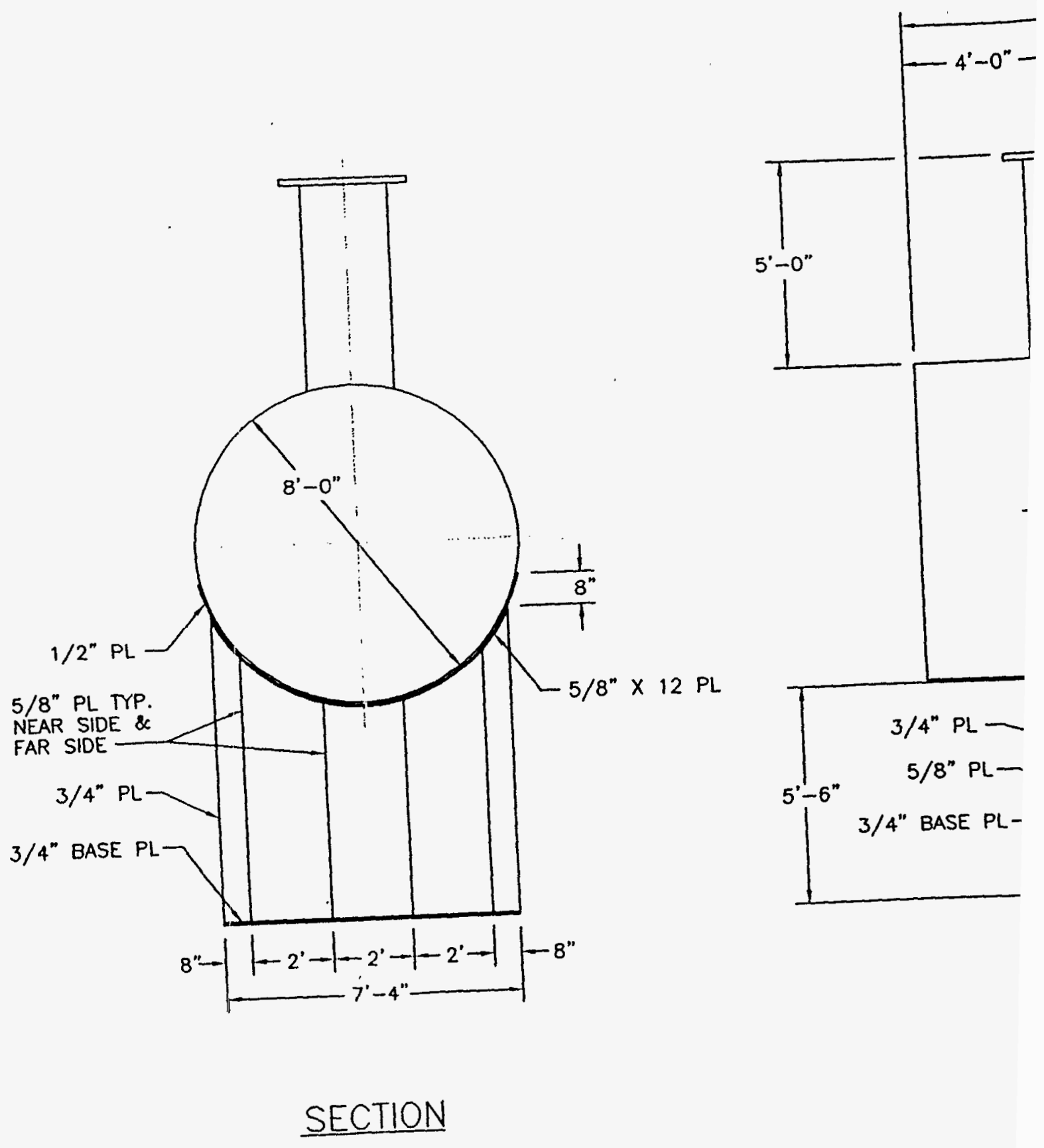
$21^{\prime}-0^{\prime \prime}$ $13^{\prime}-0^{\prime \prime}$

$26^{\prime \prime}$. 150 LB. FLANGE

$1 / 2 " \mathrm{PL}$

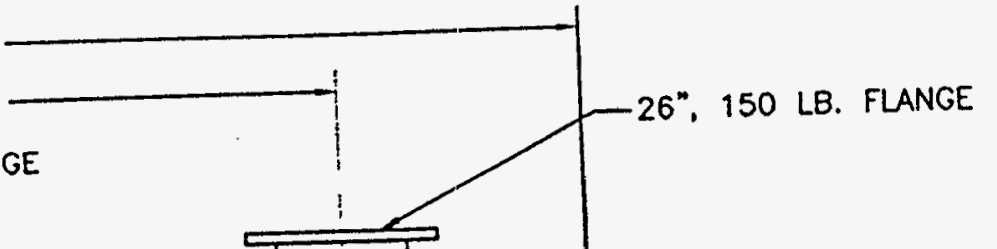

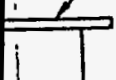

1

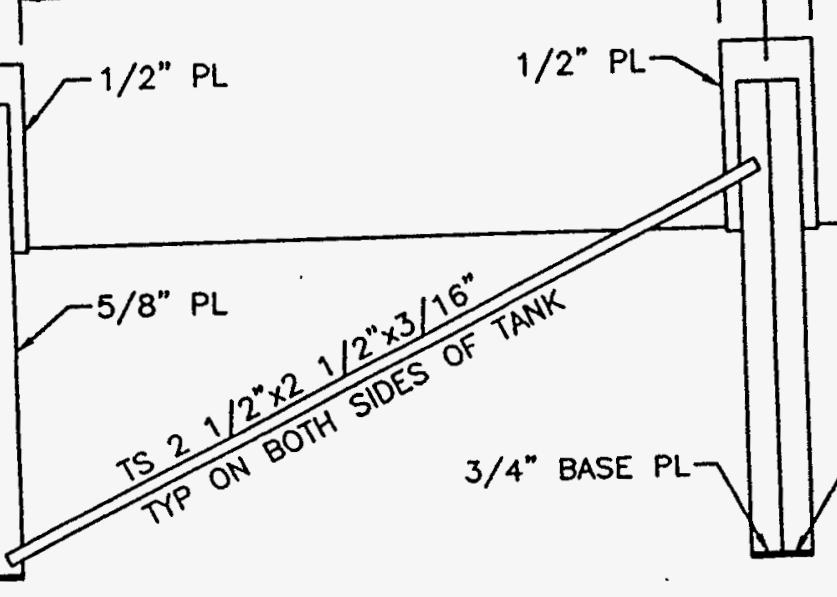

5/8" HOLE FOR

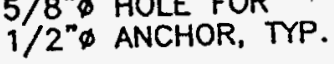

\section{ELEVATION}



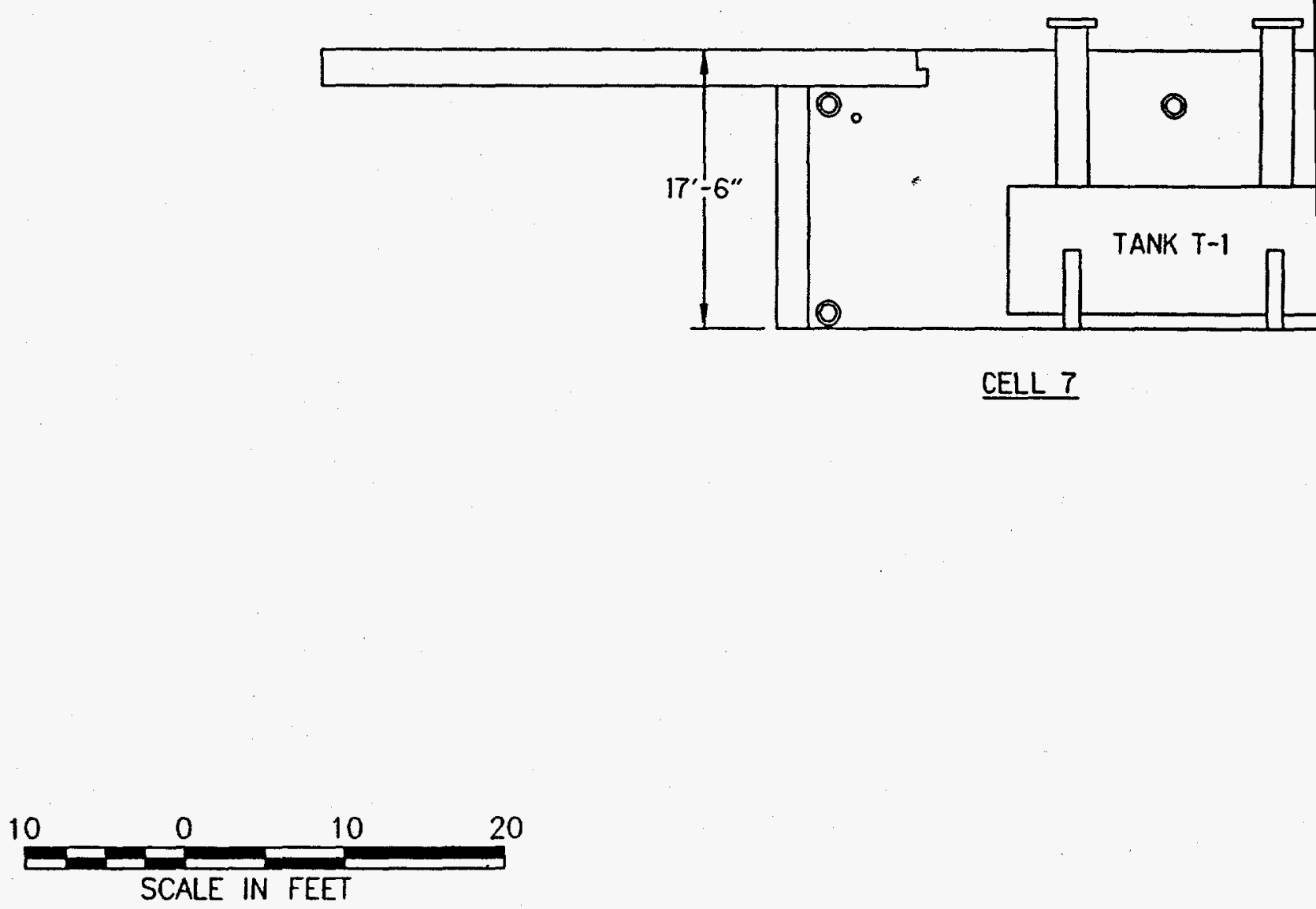


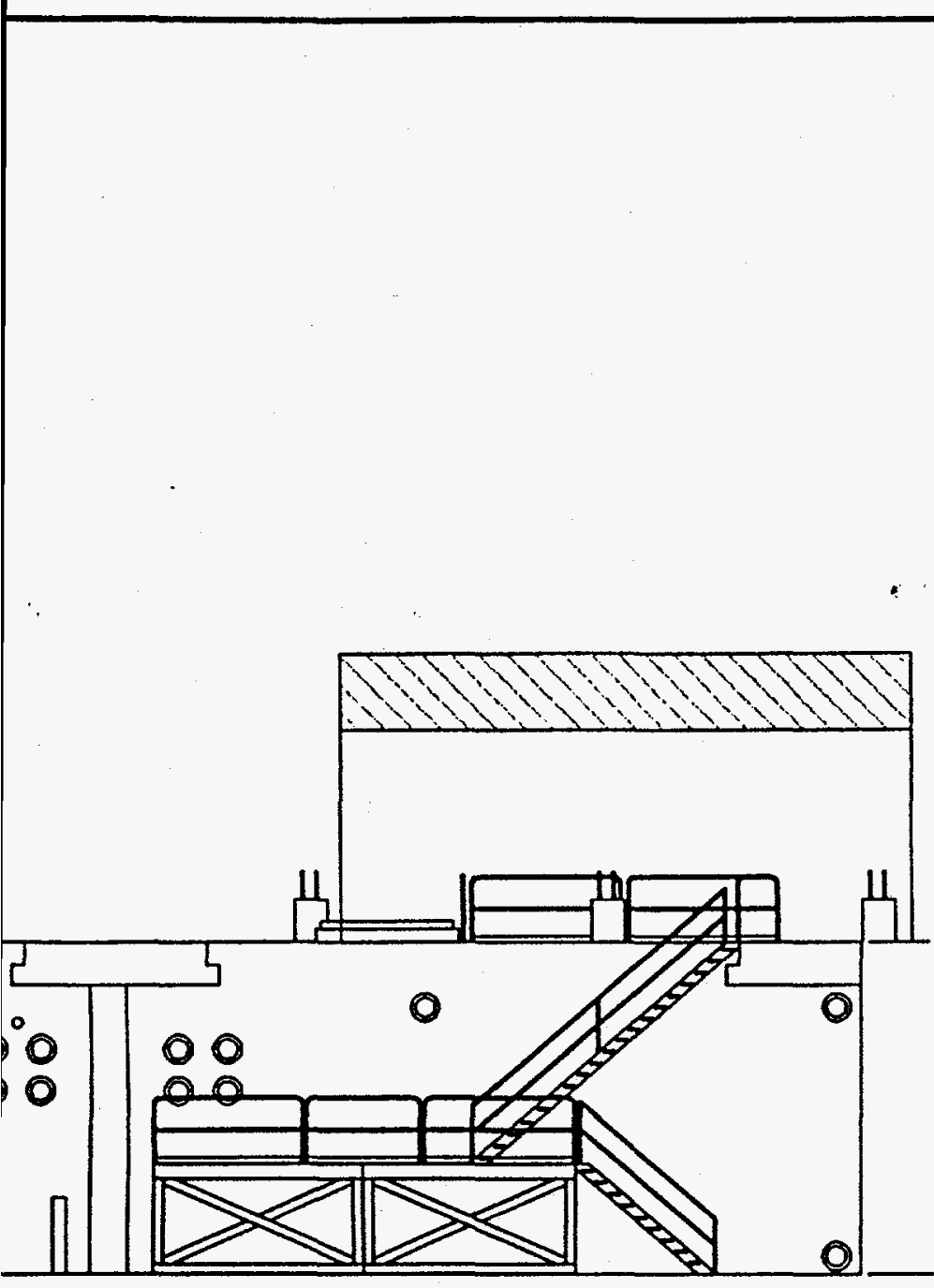

CELL 6

Fig. 2.4. Side view of cell 6 and 7 


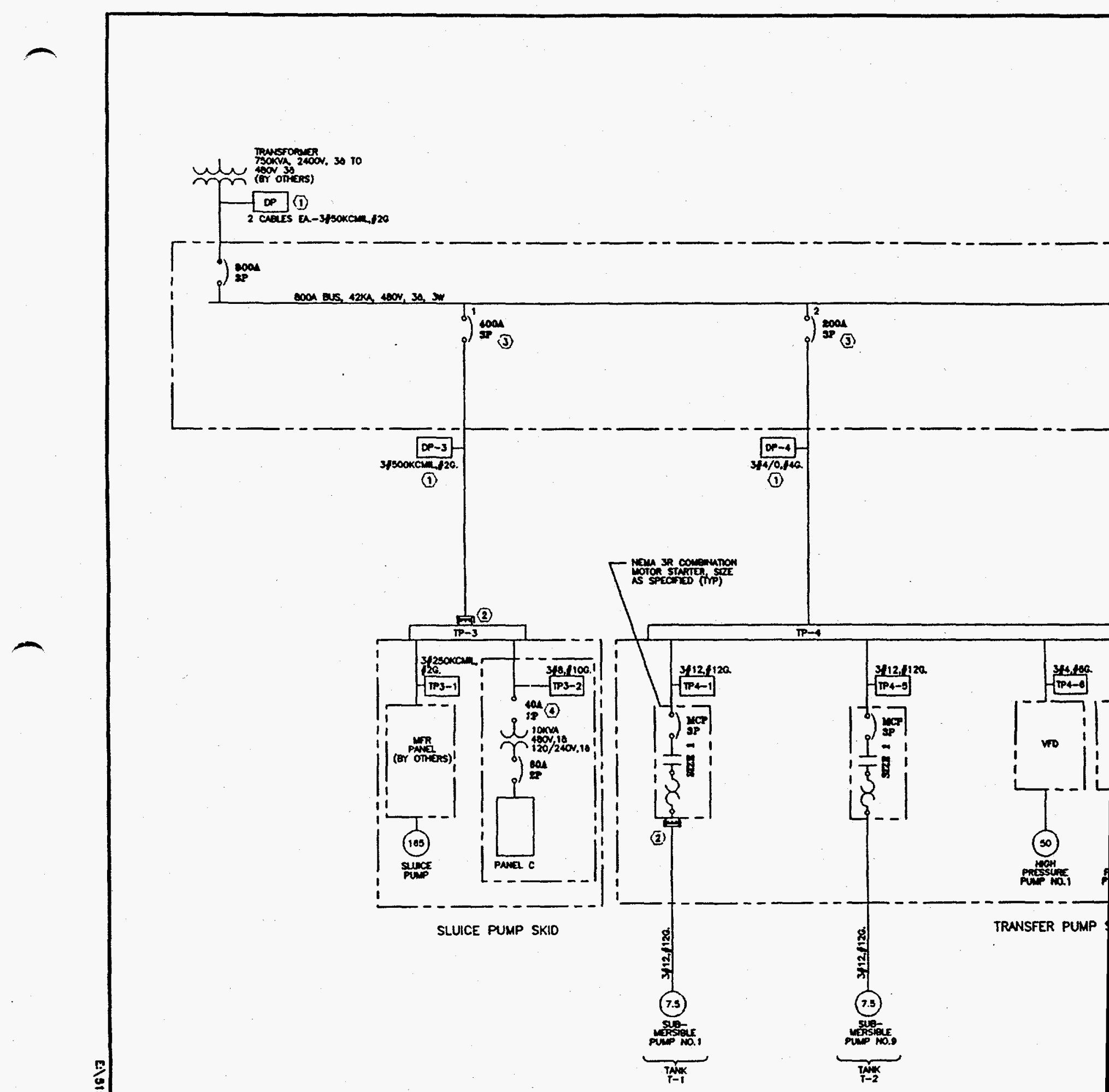




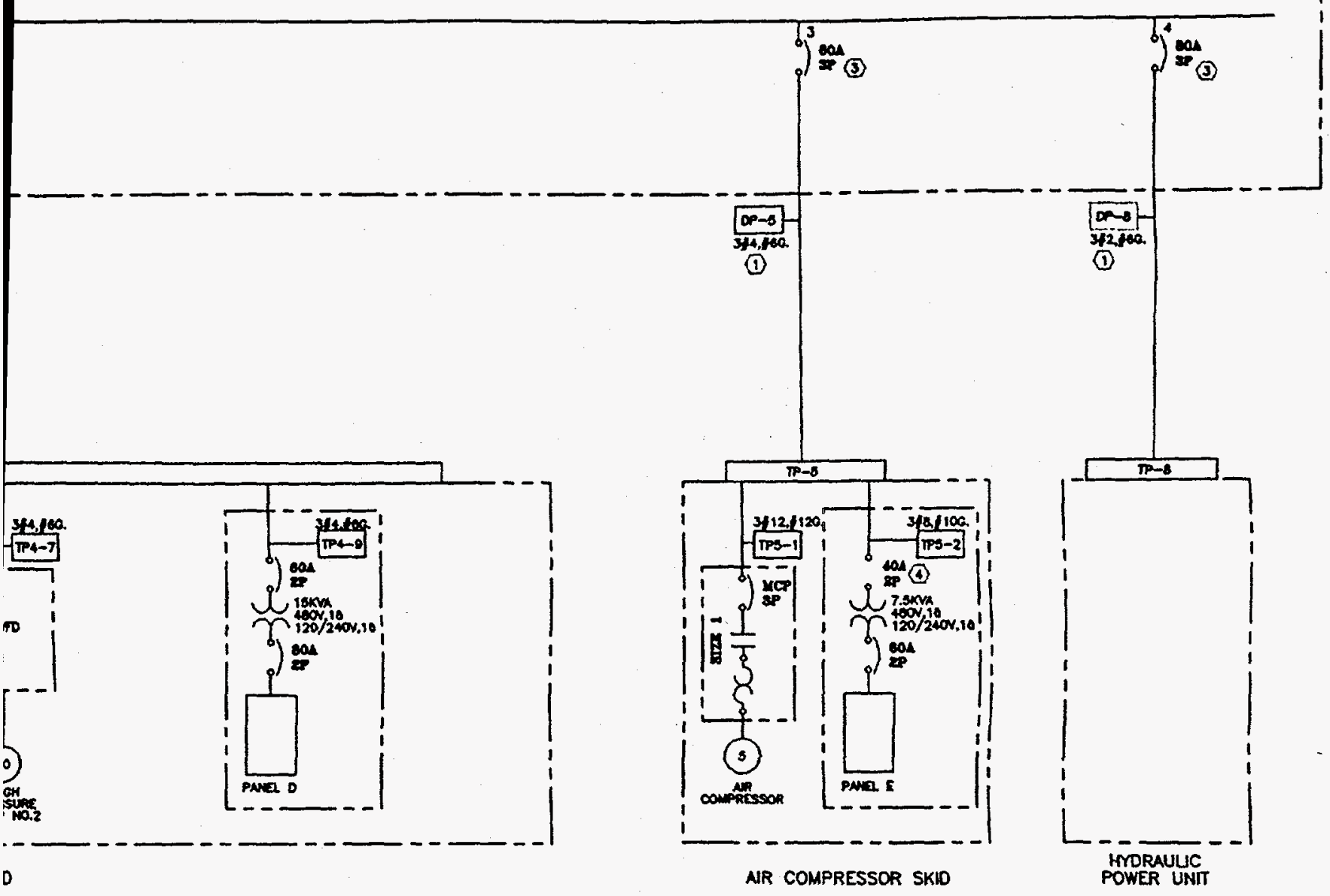

NOTES:

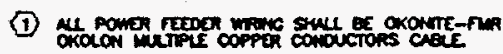

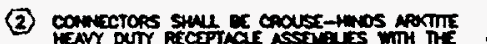

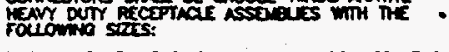

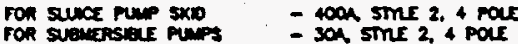

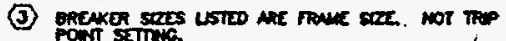

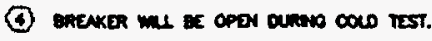

Fig. 2.5. One line diagram 
$2-7$

Table 2.1. Main distribution panel circuits

\begin{tabular}{lcc}
\hline \multicolumn{1}{c}{ Circuit } & Voltage & Breaker trip point \\
\hline Transfer pump skid & 480 volts & $200 \mathrm{amps}$ \\
Sluicer pump skid & 480 volts & $300 \mathrm{amps}$ \\
Air compressor skid & 480 volts & $20 \mathrm{amps}$ \\
Hydraulic power unit & 480 volts & 50 amps \\
\hline
\end{tabular}

\subsection{SUPPORT PERSONNEL}

Energy Systems and LMER personnel at the TTCTF will provide health and safety support, waste management services, and facility security during the cold test. 


\section{OHF COLD TEST SYSTEM CONFIGURATION}

The sluicing system tested at the TTCTF will consist of the primary equipment to be used for waste removal at the OHF. The equipment will be set up in a manner that mimics the conditions expected at the OHF.

\subsection{COLD TEST EQUIPMENT}

The cold test equipment will consist of sluicing equipment, pumping equipment, and instrumentation and controls. A process flow diagram for the cold test is presented in Fig. 3.1.

\subsubsection{Sluicing Equipment}

The sluicing system consists of:

- a sluicer pump;

- a high-pressure sluicing nozzle (also known as the Borehole Miner);

- a hydraulic power unit: and

- associated valving, monitoring, and control systems.

The sluicer pump will feed the sluicing nozzle with a mixture of sludge and supernatant supplied by the tank pumping system. The sluicer pump will be equipped with a variable speed motor that will allow the operator to vary the pump discharge pressure and flow rate up to a maximum discharge of $150 \mathrm{gpm}$ at $1500 \mathrm{psi}$.

The high-pressure sluicing nozzle will be part of a remotely operated system that will be lowered into the tank using an extendible arm. The arm can be raised or lowered and rotated to get maximum spray coverage in the tank. The arm is controlled by a hydraulic control system, which will be located in Building 7604. Details of the nozzle system design can be found in the Extendible Nozzle Water-Jetting System 90\% Design Overview (Waterjet Technology, Inc. 1997).

\subsubsection{Pumping Equipment}

The primary components of the pumping equipment are:

- a submersible pump to transfer contents from the sluice tank (T1) to recycle tank (T2);

- a submersible pump to lift contents from recycle tank and feed to the high-pressure pump;

- high-pressure pump used for recycling flow to the nozzle or for transfer to the roll-off bins that simulate the MVST:

- strainer to remove larger particles from the feed to the nozzle:

- process water system that will be used to flush lines after transfer and provide other process water needs at the site: 


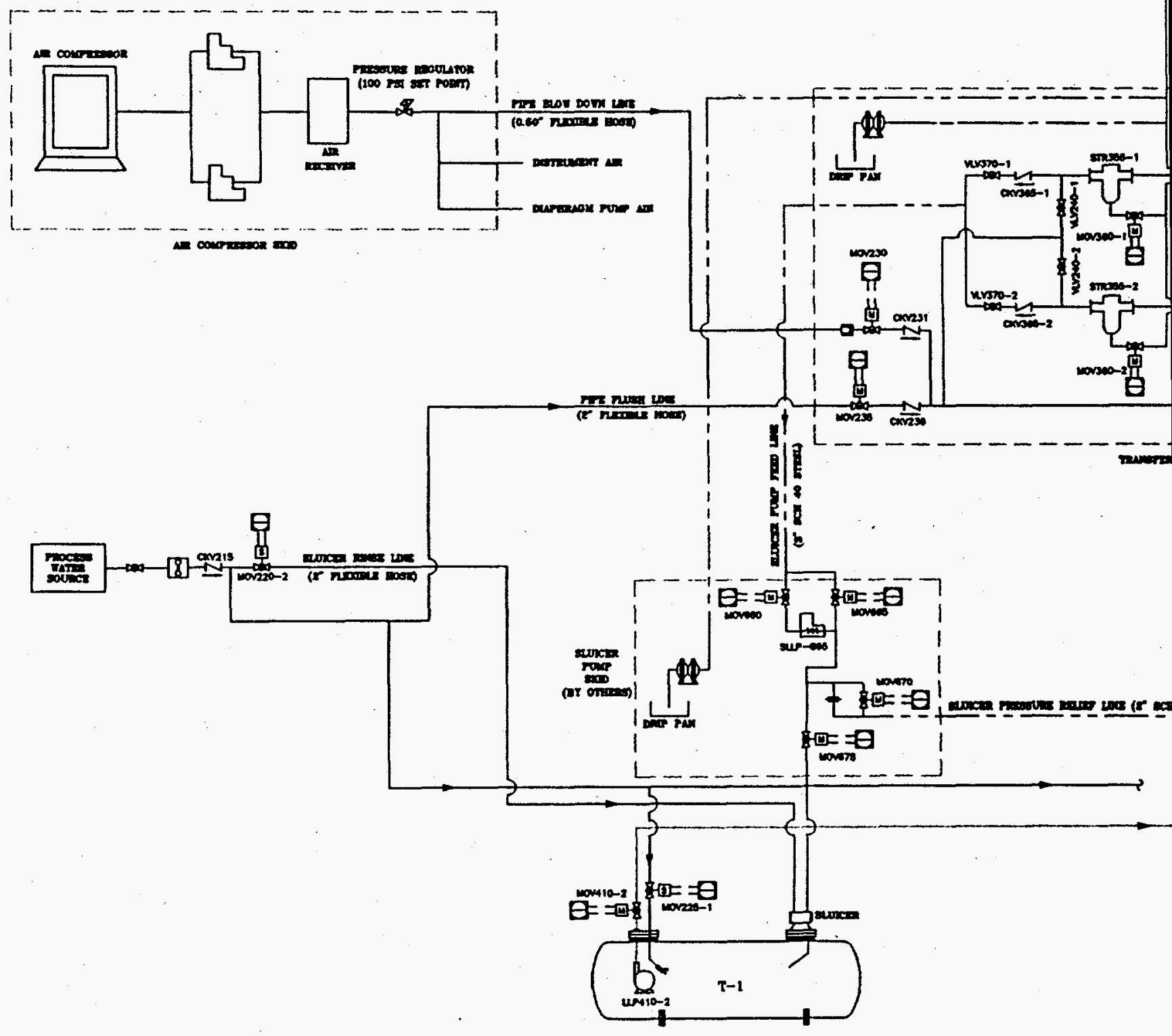




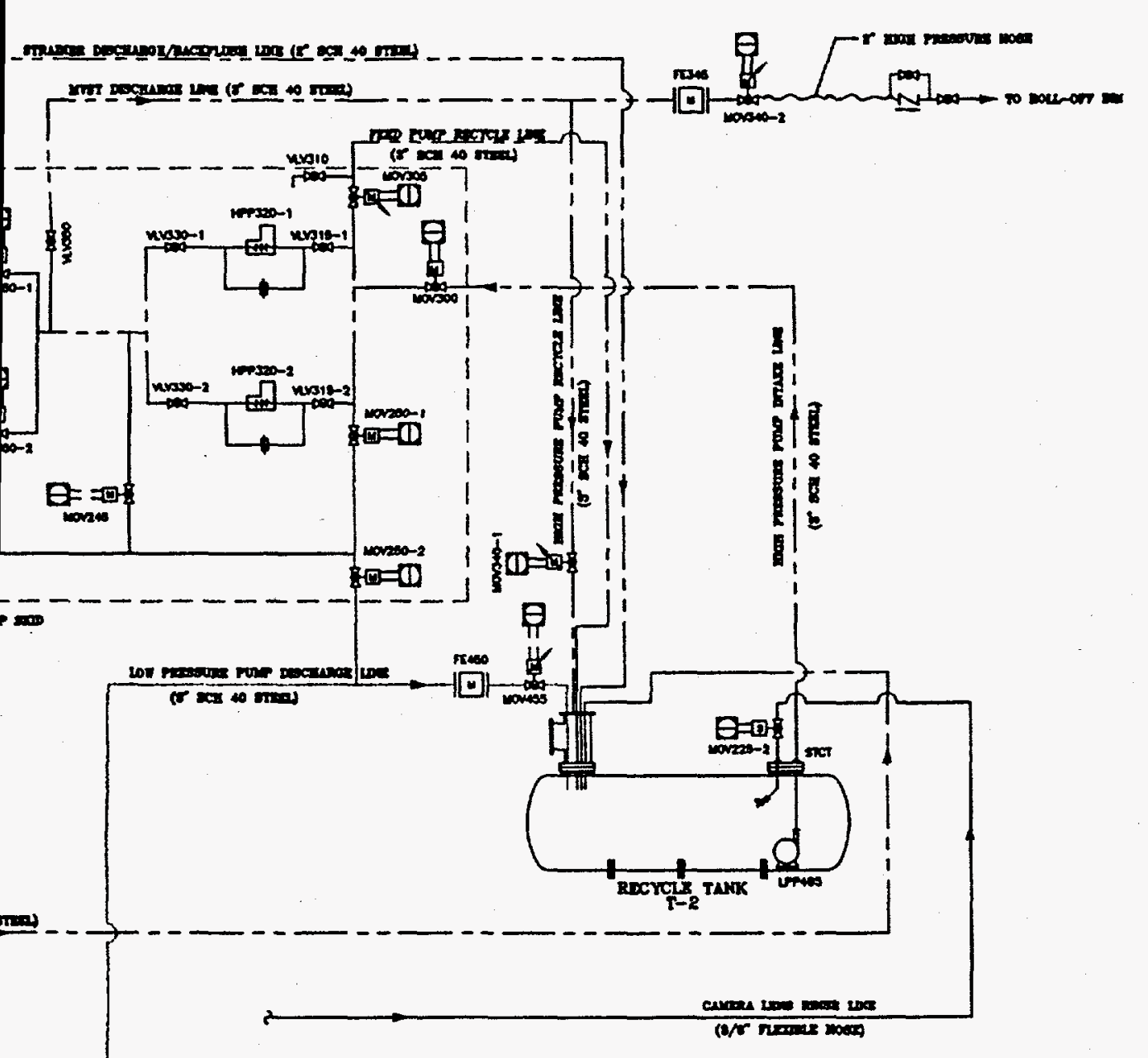

LEGEND

甲 SOLNONO OPERTIOR

I. MOTOR OPERATOR

of MODULATIO MOTOR OPERATOR

BAll VAlv

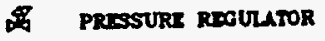

N CHDCE VAlTe

ᄀ- QURCE CONNDCTOR

a DH-TANK VDEO CANRRA

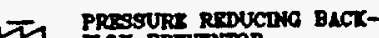

- RUPtura desx

rome surpL PORT

5ै BACKT ASHLBLI STRAOTRR

4 DOURCX DUPERACY PULP

R POSTIY DESPLACEIONT. PRockasstre CAVIT PUIT

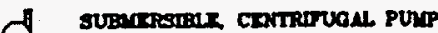

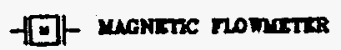

-[i]- PROPELE NOMLTIR

日 COMPUTLR CONTROL CENTIR

D ARR CONPRESSOR

亿 AIR DRYAR 
- associated piping and valves, including tank drop legs and riser modifications; and

- containment piping, riser confinement boxes, and confinement skid enclosures.

The pumping system is designed to include redundancy in the major equipment to minimize worker exposure and maintenance downtime at the OHF.

\subsubsection{Instrumentation and Controls}

Because of the radioactive nature of the materials at the OHF, extreme care must be taken to minimize any leaks or line clogging, and the system must be remotely operated. For these reasons an extensive system of monitoring, instrumentation, and controls will be required. The monitoring systems include pressure indicators, flowmeters, tank liquid-level indicators, video systems, and leak sensors in skid drip pans. Information from each of these monitoring devices will be signalled to the control system for operational monitoring, control, emergency shut-offs, alarms, etc. These systems will be tested under nonradioactive conditions in the cold test.

Control systems include a PC-based computer control panel with PLC, which will allow remote control of all system components including most of the valves, with the exception of the sluicing nozzle. The PNNL-provided nozzle will come with its own hydraulic control system. Hydraulic lines will be run from the hydraulic power unit to a nozzle control panel in the control room and to the sluicer itself. The operator will be able to control arm extension, angle, and rotation from the control console. Other information on the panel includes hydraulic pressure and operating status. Although no control features through the PLC will be available (other than pump and valve operations), information from the nozzle control panel (arm position, hydraulic pressures, etc.) will be signalled to the PLC to include alarm conditions, as well as data logging. Table 3.1 lists the parameters that are automatically logged by the PLC. Indicators listed are shown on the process and instrumentation diagrams in the $100 \%$ Configuration.

In addition to the above systems, PNNL, in conjunction with Sandia National Laboratories, will be providing a computer graphic tank visualization system. This system will use information regarding tank configuration and sluicer position (signalled by the sluicer control console) to create a computer-generated simulation of the tank interior showing the sluicer position. No control or monitoring features will be associated with this system; however, it will provide the operator with an estimated "picture" of tank sluicer position relative to the tank walls.

\subsection{EQUIPMENT LAYOUT}

The OHF sluicing system is being constructed in a modular form to allow for easy transport, set up, and dismantlement. The primary components at the cold test are the sluicer, sluicer pump skid, transfer pump skid, air compressor skid, hydraulic power unit, submersible pumps, video system, and the instrumentation and controls components. Skids and piping at the TTCTF will be installed as shown in Fig. 3.2. 
Table 3.1. Parameters automatically logged by the PLC

\begin{tabular}{|c|c|}
\hline Parameter & Indicator \\
\hline High pressure pump intake pressure & PI305 \\
\hline MVST discharge flow & FE345 \\
\hline Strainer differential pressure & Pl330, PI663 \\
\hline Tanks vacuum pressure & PI440 \\
\hline Recycle tank level & LIR445-1 \\
\hline Low pressure transfer flow & FE450 \\
\hline Demister differential pressure & PDI500 \\
\hline Ventilation temperature (upstream of heater) & TE505 \\
\hline Ventilation temperature (downstream of heater) & TE515 \\
\hline Heater differential temperature & TE505, TE515 \\
\hline $90 \%$ filter differential pressure & PDI520 \\
\hline HEPA filter differential pressure & PDI525 \\
\hline HEPA filter differential pressure & PDI530 \\
\hline Ventilation line humidity & AE535 \\
\hline Ventilation line flow & FE540 \\
\hline Sluicer system pressure. & PI625 \\
\hline Sluicer arm control pressure & PJ630 \\
\hline Sluicer extension & $\mathrm{Pl} 635$ \\
\hline Sluicer mast pressure & PI640 \\
\hline Sluicer arm range position & Zl645 \\
\hline Sluicer arm extension position & $\mathrm{Z} 1650$ \\
\hline Sluicer mast angle position & $\mathrm{ZI} 655$ \\
\hline Sluicer pump intake pressure & Pl663 \\
\hline Sluicer pump discharge pressure & PI668 \\
\hline
\end{tabular}




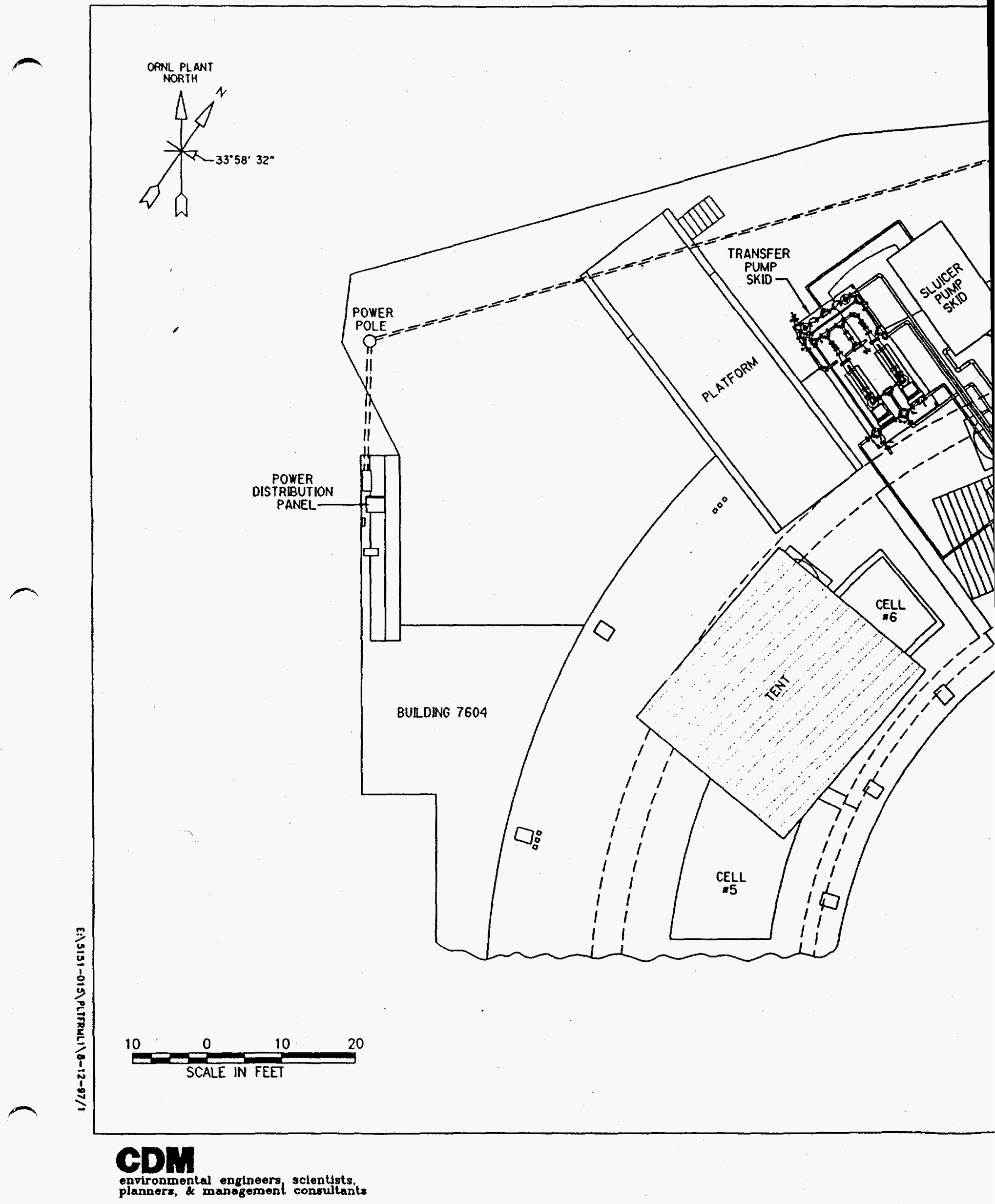




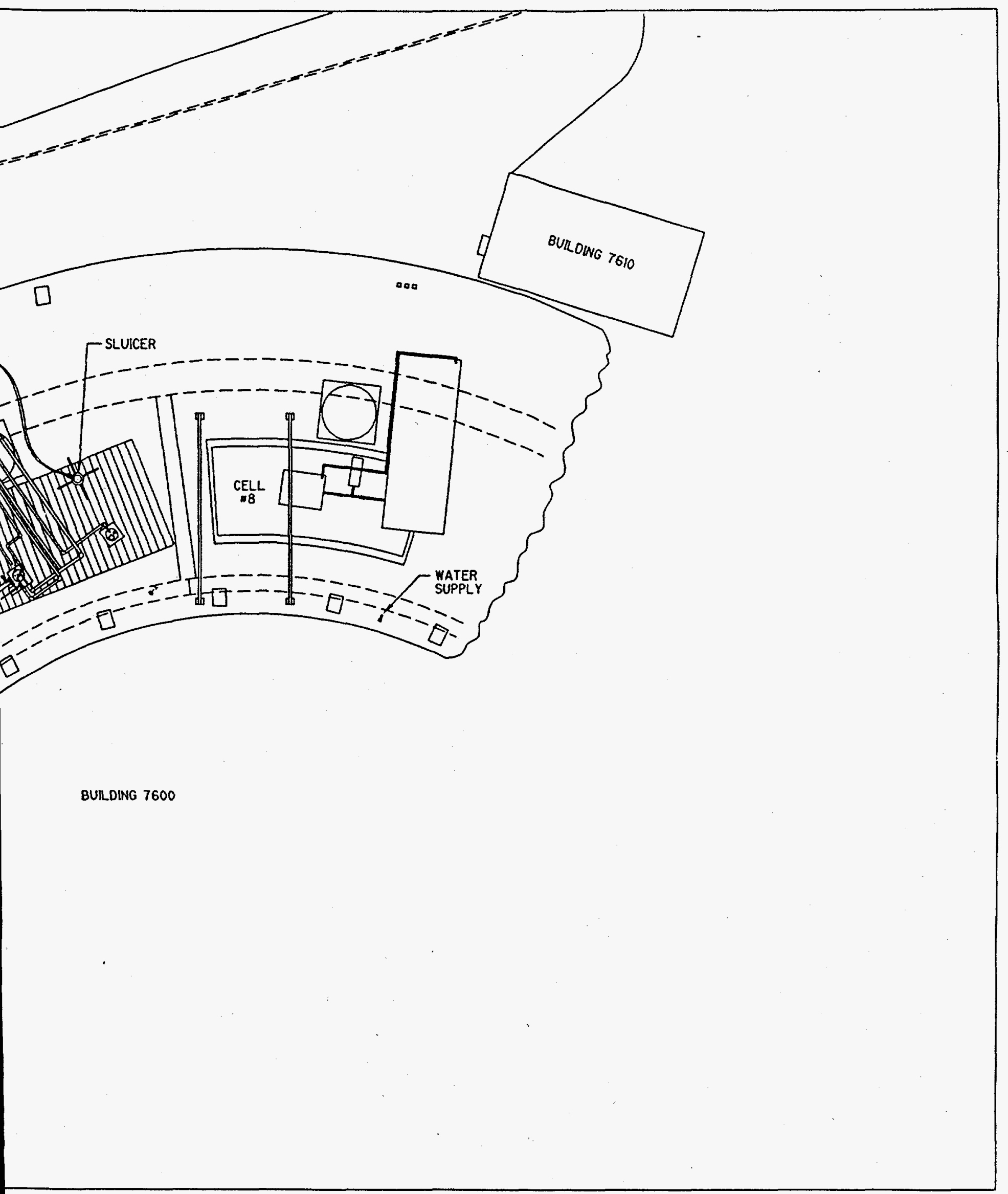

Fig. 3.2. Piping plan 


\section{COLD TEST PLAN}

The OHF sluicing system cold test is a series of system tests to evaluate the operational status of the individual components followed by full system operations testing and operator training. The full system operations and operator training include drills simulating normal and emergency operations. Before these tests, the setup described in Chaps. 2 and 3 must be complete.

Each section describes the purpose, success criteria, personnel, equipment, and steps required for completing a given test. At the completion of each test, a checklist will be completed documenting the success or failure of the system being tested. A flowchart for implementing the tests is presented in Fig. 4.1.

\subsection{SYSTEM LEAK TEST}

The system leak test is performed to hydrostatically test piping systems for structural integrity and leaks at ambient temperature. The test fluid will be clean process water containing no sludge. All piping shall be complete and pressure testing shall be conducted up to the last valve or flange in the system. System components referenced in the testing instructions are presented in Fig. 3.1.

Personnel: $\quad$ Project engineer to oversee testing

Two system operators

Special Permits: None

Special Equipment: None

Prerequisites: $\quad$ System has been set up according to the specifications described in Chaps. 2 and 3 . Successful pressure testing of the skids at the assembly shop has been documented.

Testing Instructions:

Low Pressure Transfer Pipe Test

1. Close actuated valve MOV220-2, sluicer rinse valve.

2. Close actuated valve MOV225-1, camera rinse valve.

3. Close actuated valve MOV225-2, camera rinse valve.

4. Close actuated valve MOV230, pipe blow down valve.

5. Open actuated valve MOV235, pipe flush valve.

6. Close manual valve VLV240-1, strainer STR355-1 flush valve.

7. Close manual valve VLV240-2, strainer STR355-2 flush valve. 


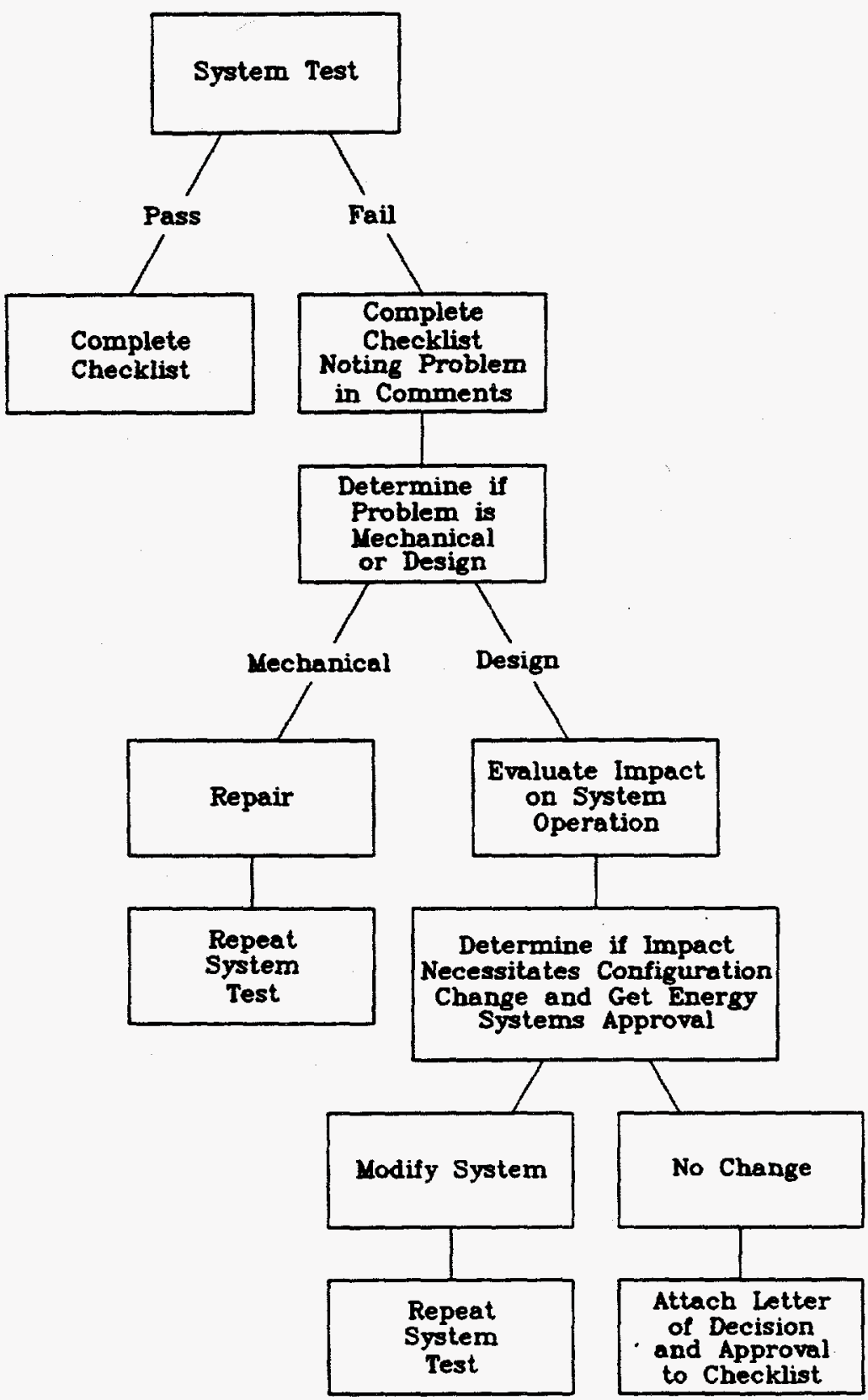

Fig. 4.1. Cold testing flowchart

Oak Ridge National Laboratory

old Hydrofracture Tank Contents Removal Project 
8. Open actuated valve MOV245, pipe flush valve.

9. Close actuated valve MOV250-1, pipe flush valve.

10. Open actuated valve MOV250-2, pipe flush valve.

11. Close manual valve VLV330-1, pump HPP320-1 discharge valve.

12. Close manual valve VLV330-2, pump HPP320-2 discharge valve.

13. Close manual valve VLV350, pump HPP350 recycle valve.

14. Close actuated valve MOV350-1, STR355-1 inlet valve.

15. Close actuated valve MOV350-2, STR355-2 inlet valve.

16. Close actuated valve MOV410-2, pump LPP410-2 discharge valve.

17. Close actuated valve MOV455, low pressure transfer throttling valve.

18. Open process water supply valve.

19. Cycle open and closed actuated valve MOV455, low pressure transfer throttling valve.

20. Cycle open and closed actuated valve MOV410-2, pump LPP410-2 discharge valve.

21. Cycle open and closed actuated valve MOV225-1, camera rinse valve.

22. Cycle open and closed actuated valve MOV225-2, camera rinse valve.

23. Record line pressure from Pl330, high pressure pump discharge pressure.

24. Visually inspect lines for leaks using soap and water on joints.

25. Close process water pump supply valve.

26. Complete checklist $4.1 \mathrm{a}$.

\section{High Pressure Pump Intake Line Test}

1. Install blind flange plates with purge valve at the riser box connection on line HS202-3, low pressure feed line.

2. Install blind flange plate with purge valve at the riser box connection on line HS203-3, low pressure feed recycle line.

3. Close actuated valve MOV220-2, sluicer rinse valve.

4. Close actuated valve MOV225-1, camera rinse valve. 
5. Close actuated valve MOV225-2, camera rinse valve.

6. Close actuated valve MOV230, pipe blow down valve.

7. Open actuated valve MOV235, pipe flush valve.

8. Close manual valve VLV240-1, strainer STR355-1 flush valve.

9. Close manual valve VLV240-2, strainer STR355-2 flush valve.

10. Close actuated valve MOV245, pipe flush valve.

11. Open actuated valve MOV250-1, pipe flush valve.

12. Close actuated valve MOV250-2, pipe flush valve.

13. Close manual valve VLV315-1, pump HPP320-1 intake valve.

14. Close manual valve VLV315-2, pump HPP320-1 intake valve.

15. Close manual valve VLV310, sample port valve.

16. Open actuated valve MOV305, pump LPP495 recycle valve.

17. Open actuated valve MOV300, pump LPP495 discharge valve.

18. Open process water supply valve.

19. Bleed air out of lines through purge valve in both blind flange plates.

20. Record line pressure from PI305, high pressure pumps intake pressure.

21. Visually inspect line for leaks using soap and water on joints.

22. Close process water pump supply valve.

23. Remove blind flange plate from line HS202-3, low pressure feed line.

24. Remove blind flange plate from line HS203-3, low pressure feed recycle line.

25. Complete checklist $4.1 \mathrm{~b}$.

High Pressure Pump Discharge Line Test

1. Install blind flange plate with purge valve at the riser box connection on line DS212-2, strainer drain line.

2. Install blind flange plate with purge valve at the riser box connection on line RS213-2, sluicer pressure relief line. 
3. Close actuated valve MOV220-2, sluicer rinse valve.

4. Close actuated valve MOV225-1, camera rinse valve.

5. Close actuated valve MOV225-2, camera rinse valve.

6. Close actuated valve MOV230, pipe blow down valve.

7. Open actuated valve MOV235, pipe flush valve.

8. Close manual valve VLV240-1, strainer STR355-1 rinse valve.

9. Close manual valve VLV240-2, strainer STR355-2, rinse valve.

10. Close actuated valve MOV250-1, pipe flush valve.

11. Close actuated valve MOV250-2, pipe flush valve.

12. Open actuated valve MOV245, pipe flush valve.

13. Close manual valve VLV315-1, pump HPP320-1 intake valve.

14. Close manual valve VLV315-2, pump HPP320-2 intake valve.

15. Open manual valve VLV330-1, pump HPP320-1 discharge valvè.

16. Open manual valve VLV330-2, pump HPP320-2 discharge valve.

17. Open manual valve VLV350, high pressure recycle valve.

18. Open actuated valve MOV340-2, MVST transfer valve.

19. Close manual valve at roll-off bin discharge.

20. Close actuated valve MOV340-1, high pressure recycle valve.

21. Open actuated valve MOV350-1, strainer STR355-1 inlet valve.

22. Open actuated valve MOV350-2, strainer STR355-2 inlet valve.

23. Open actuated valve MOV360-1, strainer STR355-1 drain valve.

24. Open actuated valve MOV360-2, strainer STR355-2 drain valve.

25. Open manual valve VLV370-1, strainer STR355-1 isolation valve.

26. Open manual valve VLV370-2, strainer STR355-2 isolation valve.

27. Open actuated valve MOV660, pump SLCP665 intake valve. 
28. Open actuated valve MOV665, pump SLCP665 bypass valve.

29. Open actuated valve MOV670, sluicer pressure relief valve line.

30. Close actuated valve MOV675, sluicer valve.

31. Open process water supply valve.

32. Bleed air out of lines through purge valve in both blind flange plates.

33. Cycle open and closed actuated valve MOV340-1, high pressure pumps recycle valve.

34. Bleed air out of MVST transfer hose by opening the roll-off bin discharge valve.

35. Record line pressure from PI330, high pressure pumps discharge pressure.

36. Visually inspect line for leaks.

37. Close process water pump supply valve.

38. Remove blind flange plate from line DS212-2, strainer drain line.

39. Remove blind flange plate from line RS213-2, sluicer pressure relief line.

40. Complete checklist $4.1 \mathrm{c}$.

\subsection{INSTRUMENTATION AND CONTROLS TEST}

The purpose of the control test is to demonstrate the functionality and performance of the monitoring and control system as an integrated system including all applicable hardware and software.

\subsubsection{Field Instrumentation and Equipment Tagging Verification Test}

The purpose of the field instrumentation and equipment tagging verification test is to verify that all instruments and equipment have been tagged properly. Details of the test are as follows:

Minimum Personnel Required: Project engineer, one system operator, and one I\&C engineer

Special Permits: None

Special Equipment: None

Prerequisites: $\quad$ Before this test, the system must be installed as described in Chaps. 2 and 3. 
Testing Instructions:

1. Using the Process and Instrumentation Diagrams, I-2, I-3, I-4, I-5, I-6, perform a walkdown of the system and verify tag identifications are installed and labeled correctly.

2. Complete checklist 4.2.1 in Appendix A.

\subsubsection{PLC, Workstation and Panel Audit Test}

The purpose of the PLC, workstation and panel audit test is to verify that all equipment required has been provided and installed correctly. Details of the test are as follows:

Minimum Personnel Required: Project engineer, one system operator, and one I\&C engineer

Special Permits: None

Special Equipment: 4-20 mA signal generator and indicator, digital multimeter, 120 VAC jumper, standard technician's tool kit.

Prerequisites:

Before this test, the system must be installed as described in Chaps. 2 and 3.

Testing Instructions:

1. Using Process and Instrumentation Diagram I-7, verify that the workstation equipment, PLC equipment and cables have been installed and labeled correctly.

2. Using Process and Instrumentation Diagram 1-7, verify that the main control panel layout is correct, physical appearance and workmanship of panel is acceptable.

3. Complete checklist 4.2.2 in Appendix A.

\subsubsection{Process $\mathrm{V} / \mathrm{O}$ Verification Test}

The purpose of the process $\mathrm{I} / \mathrm{O}$ verification test is to verify that the connection between each process $\mathrm{I} / \mathrm{O}$ and PLC is properly configured and installed. Details of the test are as follows:

Minimum Personnel Required: Project engineer, one system operator, and one I\&C engineer

Special Permits: None

Special Equipment: $\quad 4-20 \mathrm{~mA}$ signal generator and indicator, digital multimeter, 120 VAC jumper, standard technician's tool kit.

Prerequisites:

Before this test, the system must be installed as described in Chaps. 2 and 3. PLC, Workstation and Panel Audit Test has been completed successfully. 
Testing Instructions:

1. Use the $\mathrm{I} / \mathrm{O}$ database checklist 4.2 .3 in Appendix A.

2. Log on to the workstation with a typical Operator control access account.

3. Select the first discrete input module on the checklist.

4. Using input simulation equipment, force a state of change for each discrete input point. Verify that the change is reflected on the appropriate graphic display.

5. Repeat step 4 for all discrete input modules.

6. Select the first analog input module.

7. Using input simulation equipment, perform a range check at $0 \%, 50 \%$, and $100 \%$ for each analog input point. Verify that the input value is reflected on the appropriate graphic display.

8. Repeat step 7 for all analog input modules.

9. Select the first discrete output module. Using the appropriate graphic display, force a change of state to occur at the operator workstation. Using a monitoring device, verify that the appropriate state change occurs.

10. Repeat step 9 for all discrete output modules.

11. Select the first analog output module. Using the appropriate graphic display, place all $A O$ points in Manual and output values of $0 \%, 50 \%$, and $100 \%$. Using a monitoring device, verify that the appropriate reading occurs at each value entered.

12. Repeat step 11 for all analog output modules.

\subsubsection{PLC, Workstation, and Panel Failure Test}

The purpose of the PLC, workstation, and panel failure test is to verify that proper system failure response, notification and recovery function properly. Details of the test are as follows:

Minimum Personnel Required: Project engineer, one system operator, and one I\&C engineer

Special Permits: None

Special Equipment: None

Prerequisites: $\quad$ Before this test, the system must be installed as described in Chaps. 2 and 3. PLC, Workstation, and Panel Audit Test has been completed successfully. Process I/O verification test has been completed successfully. 
Testing Instructions:

1. Remove power from main control panel UPS and verify that failure is Alarmed at workstation and that there is a bumpless transfer to UPS battery power and the PLC and workstation are still operating. Also verify that all $1 / O$ readings are the same (i.e., phased power from primary to auxiliary is the same).

2. Maintain power outage and verify UPS maintains power for 5 minutes.

3. Restore power to main control panel UPS and verify that failure Alarm is cleared at workstation and that system recovers without disrupting operation of PLC and workstation.

4. Remove power from workstation and verify that PLC maintains control and no process upsets occur.

5. Restore power to workstation and verify that workstation recovers automatically, boots up and processes information, and no process upsets occur.

6. Remove power from PLC and verify that a PLC Failure Alarm is generated at the workstation.

7. Restore power to PLC and verify that the PLC Failure Alarm is cleared and the PLC recovers automatically and no process upsets occur.

8. Remove power from PLC Remote I/O and verify that a Remote I/O Failure Alarm is generated at the workstation.

9. Restore power to PLC Remote I/O and verify that the Remote I/O Failure Alarm is cleared and the Remote I/O recovers automatically and no process upsets occur.

10. Remove communications cable between workstation and PLC and verify a Communications Failure Alarm is generated at the workstation and both PLC and workstation continue to operate normally.

11. Restore communications cable between workstation and PLC and verify Communications Failure Alarm is cleared, communication is re-established automatically, and no process upsets occur.

12. Complete checklist 4.2.4 in Appendix A.

\subsubsection{Process Control Verification Test}

The purpose of the process control verification test is to verify that the control strategies for the OHF Sluicing System exist and operate per the design. The testing will be accomplished on a loop-by-loop basis. After successful completion of this test the system is ready for complete automatic operation. Details of the test are as follows:

Minimum Personnel Required: Project engineer, one system operator, and one I\&C engineer

Special Permits: None 
Special Equipment:

Prerequisites:
4-20 $\mathrm{mA}$ signal generator and indicator, digital multimeter, 120 VAC jumper, standard technicians tool kit.

Before this test, the system must be installed as described in Chaps. 2 and 3. PLC, Workstation and Panel Audit Test has been completed successfully. Process $\mathrm{V} / \mathrm{O}$ verification test has been completed successfully. PLC, Workstation, and Panel Failure Test has been completed successfully.

Testing Instructions:

1. Log on to the workstation with a typical Operator control access account.

2. Switch all equipment to the Local or Off position.

3. At the workstation, place all controlled equipment in the Computer Manual mode.

4. Verification of Loop 205 Process Water Pump and Loop 210 Process Water Flow is accomplished by completing the instructions in checklist 4.2.5.1 in Appendix A.

5. Verification of Loop 220-2 Sluicer Rinse Valve is accomplished by completing the instructions in checklist 4.2.5.2.

6. Verification of Loop 225-1 Recycle Tank Camera Lens Rinse Valve is accomplished by completing the instructions in checklist 4.2.5.3.

7. Verification of Loop 225-2 Old Hydrofracture Tank Camera Lens Rinse Valve is accomplished by completing the instructions in checklist 4.2.5.4.

8. Verification of Loop 230 Pipe Blow Down Valve is accomplished by completing the instructions in checklist 4.2.5.5.

9. Verification of Loop 235 Pipe Flush Valve is accomplished by completing the instructions in checklist 4.2.5.6.

10. Verification of Loop 245 High Pressure Pumps Discharge Header Flush Valve is accomplished by completing the instructions in checklist 4.2.5.7.

11. Verification of Loop 250-1 High Pressure Pumps Suction Header Flush Valve is accomplished by completing the instructions in checklist 4.2.5.8.

12. Verification of Loop 250-2 Low Pressure Pumps Discharge Line Flush Valve is accomplished by completing the instructions in checklist 4.2.5.9.

13. Verification of Loop 300 Recycle Tank Discharge Valve is accomplished by completing the instructions in checklist 4.2.5.10.

14. Verification of Loop 305 High Pressure Pumps Intake Line Pressure and Recycle Valve is accomplished by completing the instructions in checklist 4.2.5.11. 
15. Verification of Loop 320-1 High Pressure Transfer Pump 1 is accomplished by completing the instructions in checklist 4.2.5.12.

16. Verification of Loop 320-2 High Pressure Transfer Pump 2 is accomplished by completing the instructions in checklist 4:2.5.13.

17. Verification of Loop 330 High Pressure Transfer Line Pressure is accomplished by completing the instructions in checklist 4.2.5.14.

18. Verification of Loop 340-1 High Pressure Recycle Valve is accomplished by completing the instructions in checklist 4.2.5.15.

19. Verification of Loop 340-2 MVST Discharge Valve is accomplished by completing the instructions in checklist 4.2.5.16.

20. Verification of Loop 345 MVST Discharge Flow is accomplished by completing the instructions in checklist 4.2.5.17.

21. Verification of Loop 350-1 Strainer Valve 1 is accomplished by completing the instructions in checklist 4.2.5.18.

22. Verification of Loop 350-2 Strainer Valve 2 is accomplished by completing the instructions in checklist 4.2.5.19.

23. Verification of Loop 360-1 Strainer Drain Valve 1 is accomplished by completing the instructions in checklist 4.2.5.20.

24. Verification of Loop 360-2 Strainer Drain Valve 2 is accomplished by completing the instructions in checklist 4.2.5.21.

25. Verification of Loop 410-1 Old Hydrofracture Tank Pump 1 is accomplished by completing the instructions in checklist 4.2.5.22.

26. Verification of Loop 410-2 Old Hydrofracture Tank Pump 2 is accomplished by completing the instructions in checklist 4.2.5.23.

27. Verification of Loop 410-1 Tank 1 Pump Discharge Valve 1 is accomplished by completing the instructions in checklist 4.2.5.24.

28. Verification of Loop 410-2 Tank 1 Pump Discharge Valve 2 is accomplished by completing the instructions in checklist 4.2.5.25.

29. Verification of Loop 445 Bubbler System Air Pressure is accomplished by completing the instructions in checklist 4.2.5.26.

30. Verification of Loop 445-1 Recycle Tank Level (Bubbler System) is accomplished by completing the instructions in checklist 4.2.5.27. 
31. Verification of Loop 445-2 Old Hydrofracture Tank Level (Bubbler System) is accomplished by completing the instructions in checklist 4.2 .5 .28 .

32. Verification of Loop 445-3 Old Hydrofracture Tank Level (Bubbler System) is accomplished by completing the instructions in checklist 4.2.5.29.

33. Verification of Loop 450 Low Pressure Transfer Flow is accomplished by completing the instructions in checklist 4.2.5.30.

34. Verification of Loop 455 Low Pressure Transfer Throttling Valve is accomplished by completing the instructions in checklist 4.2.5.31.

35. Verification of Loop 495 Recycle Tank Pump is accomplished by completing the instructions in checklist 4.2.5.32.

36. Verification of Loop 600 Sluicer Control Console Power is accomplished by completing the instructions in checklist 4.2.5.33.

37. Verification of Loop 605 Sluicer Control Console System On is accomplished by completing the instructions in checklist 4.2.5.34.

38. Verification of Loop 610 Sluicer Control Console Emergency Stop is accomplished by completing the instructions in checklist 4.2.5.35.

39. Verification of Loop 615 Sluicer System Hydraulic Power is accomplished by completing the instructions in checklist 4.2.5.36.

40. Verification of Loop 625 Sluicer System Pressure is accomplished by completing the instructions in checklist 4.2.5.37.

41. Verification of Loop 630 Sluicer Arm Control Pressure is accomplished by completing the instructions in checklist 4.2.5.38.

42. Verification of Loop 635 Sluicer Extension Pressure is accomplished by completing the instructions in checklist 4.2.5.39.

43. Verification of Loop 640 Sluicer Mast Pressure is accomplished by completing the instructions in checklist 4.2.5.40.

44. Verification of Loop 645 Sluicer Arm Range is accomplished by completing the instructions in checklist 4.2.5.41.

45. Verification of Loop 650 Sluicer Arm Extension is accomplished by completing the instructions in checklist 4.2.5.42.

46. Verification of Loop 655 Sluicer Mast Angle is accomplished by completing the instructions in checklist 4.2.5.43. 
47. Verification of Loop 660 Sluicer Pump Intake Valve is accomplished by completing the instructions in checklist 4.2.5.44.

48. Verification of Loop 663 Sluicer Pump Intake Pressure is accomplished by completing the instructions in checklist 4.2.5.45.

49. Verification of Loop 665 Sluicer Pump is accomplished by completing the instructions in checklist 4.2.5.46.

50. Verification of Loop 665A Sluicer Pump Bypass Valve is accomplished by completing the instructions in checklist 4.2.5.47.

51. Verification of Loop 668 Sluicer Pump Discharge Pressure and Loop 670 Sluicer Pressure Release Valve is accomplished by completing the instructions in checklist 4.2.5.48.

52. Verification of Loop 675 Sluicer Pump Discharge Valve is accomplished by completing the instructions in checklist 4.2.5.49.

53. Verification of Loop 700 Radiation Monitor - Recycle Tank is accomplished by completing the instructions in checklist 4.2.5.50.

54. Verification of Loop 705 Radiation Monitor - Hydrofracture Tank is accomplished by completing the instructions in checklist 4.2.5.51.

55. Verification of Loop 710 Radiation Monitor - Pumping Skid is accomplished by completing the instructions in checklist 4.2.5.52.

\subsection{SUPPORT SYSTEM TEST}

The OHF tank sluicing system has two supporting systems, the process water system and the compressed air system. At the OHF site, the process water system will consist of a process water storage tank, a pump, a flowmeter, and a control valve. Only the flowmeter and control valve are being installed for the cold test.

\subsubsection{Air Compressor Test}

The compressed air system consists of an air compressor, air dryers, air receiver, and pressure regulating valve. This system will be inspected by one of the operators to verify it is operating correctly. This inspection will be facilitated by the compressed air system checklist (checklist 4.3.1 in Appendix A).

\subsubsection{Process Water Test}

The purpose of the process water test is to verify the proper operation of the process water system as installed at the TTCTF. This will be accomplished by an off-line flush of the strainers (Fig. 4.2). 


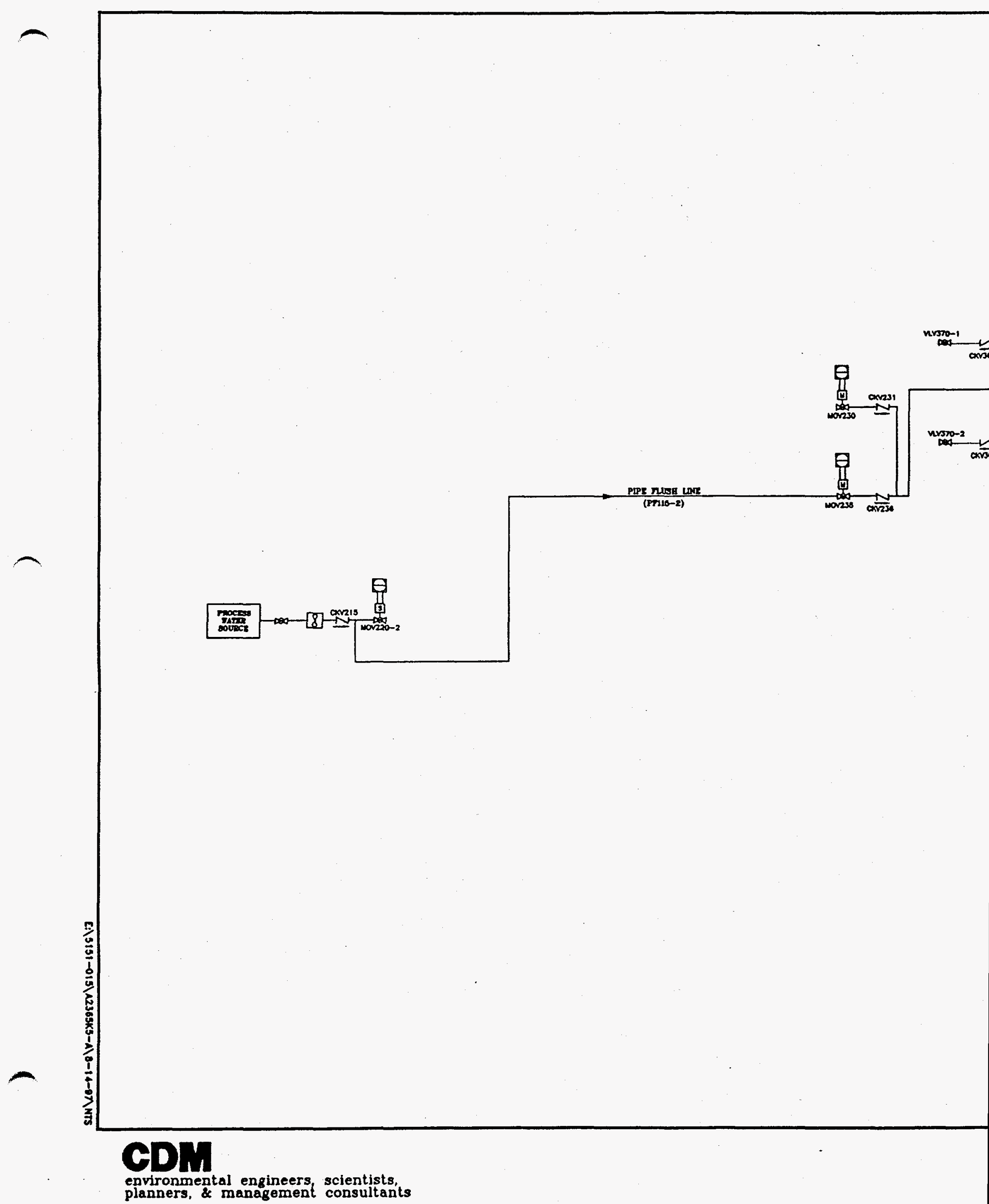




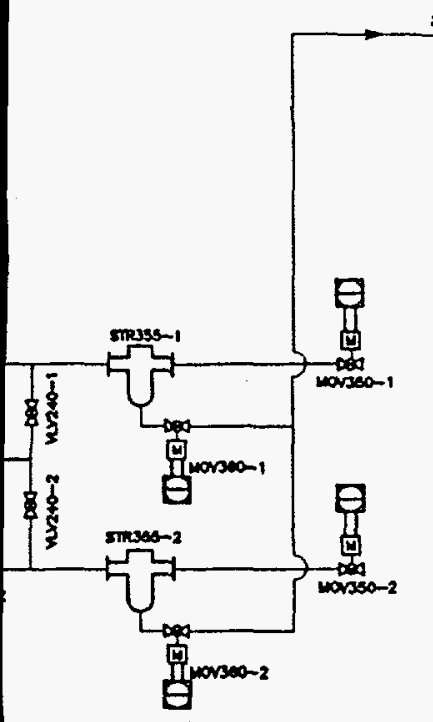

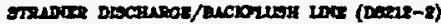

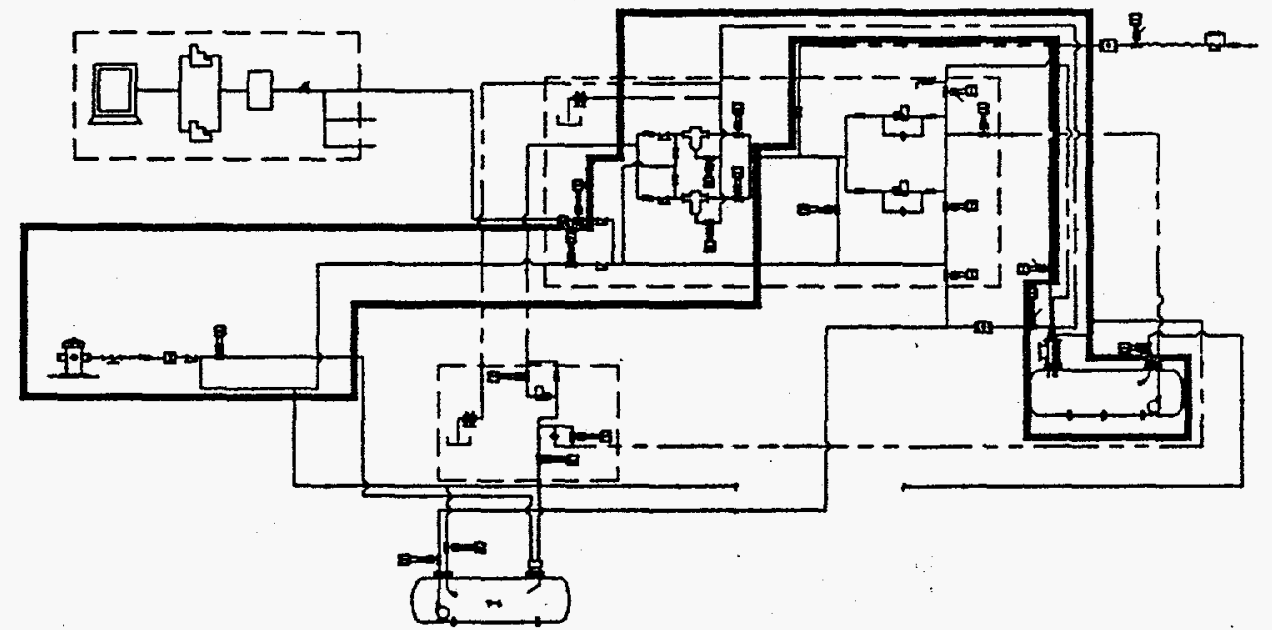

Fig. 4.2. Process water test

Oak Ridge National Laboratory old Hydrofracture Tank Contents Removal Project 
Minimum Personnel Required: Project Engineer to oversee the testing

Two system operators to conduct the test

Special Permits: $\quad$ None

Special Equipment: None

Prerequisites: $\quad$ System has been set up according to specifications described in Chaps. 2 and 3.

Testing Instructions:

1. Flush both strainers by the method described in Work Instruction 4 - Off-Line Strainer Flushing.

2. Complete checklist 4.3.2 in Appendix A.

\subsection{CLEAN WATER CAPACITY TEST}

The clean water capacity test is a series of pumping tests to evaluate the performance of the strainers (2) during flushing, the submersible pumps (2), the high pressure pumps (2), and the sluicer pump (1). These tests will be used to determine the flow and pressure ranges that can be expected and to test the configuration's protective features (i.e., pressure alarms and rupture disks).

\subsubsection{Submersible Pump Test}

The purpose of the submersible pump test is to evaluate the performance of the submersible pumps by operating the recycle tank pump in a recirculation mode using supernatant only (Fig. 4.3). For system success, the submersible pump must have a deadhead pressure less than 75 psi, must start/stop upon command from the PLC, and must not jump excessively on startup. Details of the test are as follows:

Minimum Personnel Required: Project Engineer to oversee the testing

Two system operators to conduct the test

Special Permits: $\quad$ None

Special Equipment: $\quad$ Portable, strap-on flowmeter

Prerequisites: $\quad$ Before this test, the system must be installed as described in Chaps. 2 and 3 and the system must have successfully completed the leak test and control test. The recycle tank must contain 3400 gal of solids-free water.

Testing Instructions:

1. Install the portable flowmeter on the high pressure pump intake line (HS202-3) to measure test flow rate. 


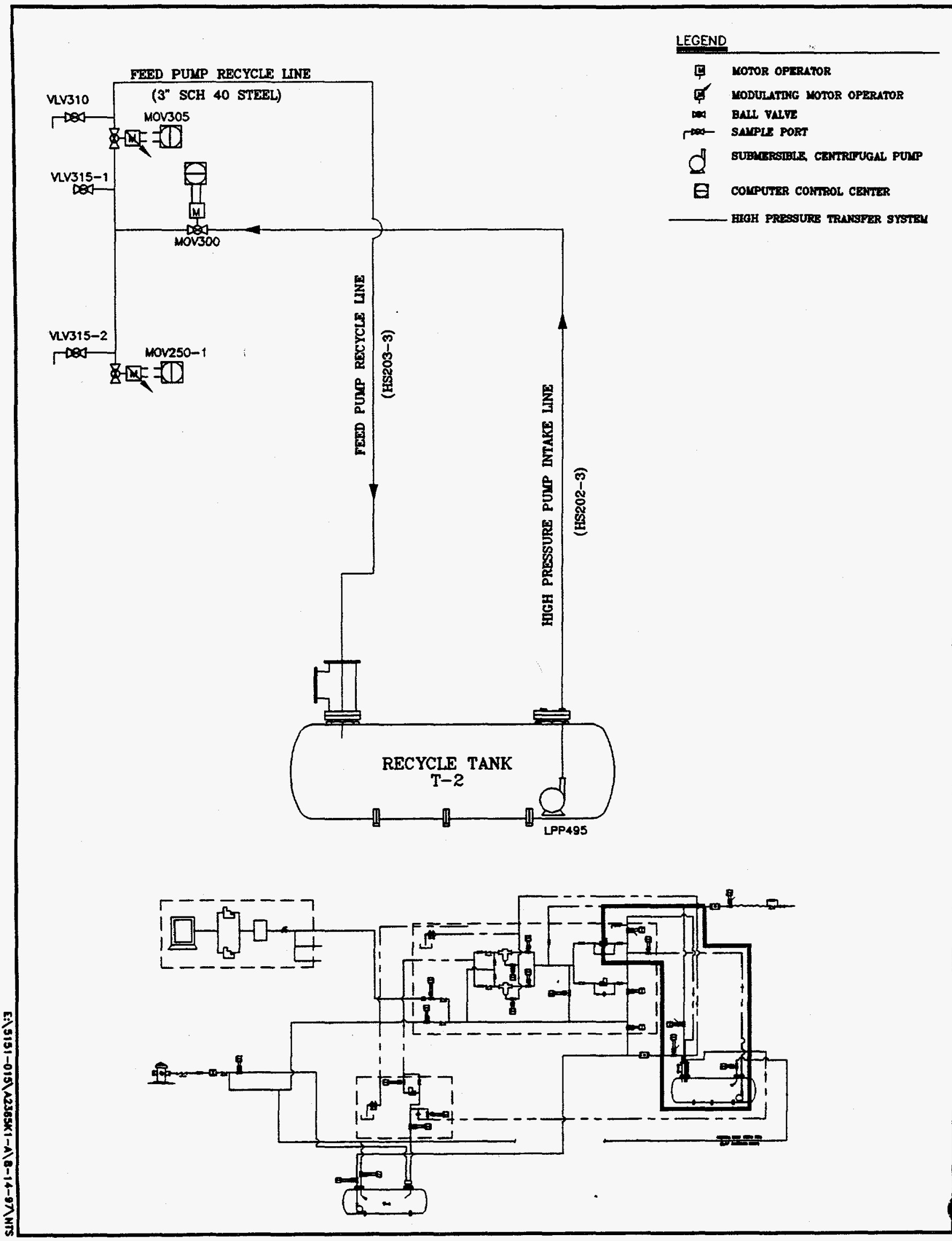

Fig. 4.3. Submersible pump

Oak Ridge National Laboratory old Hydrofracture Tank Contents. Removal Project 
2. Verify the local switch for pump LPP495 is in the REMOTE position to allow PLC control of the pump.

3. Close manual valve VLV310 (sample port valve).

4. Close manual valve VLV315-1 (high pressure pump HPP320-1 intake valve).

5. Close manual valve VLV315-2 (high pressure pump HPP320-2 intake valve).

6. From the PLC, close actuated valve MOV250-1 (recycle tank bypass valve).

7. From the PLC, close actuated valve MOV305 (submersible pump recycle valve).

8. From the PLC, open actuated valve MOV300 (submersible pump discharge valve).

9. Turn on recycle tank camera and observe pump LPP495.

10. From the PLC, start LPP495 while observing pump with camera. Make note of any pump movement (jumping) that may be significant enough to damage the equipment.

11. Record deadhead pressure from PI305 at the PLC.

12. From the PLC, open actuated valve MOV $30520 \%$ and let run for 5 minutes. Record stabilized pressure from pressure gauge PI 305 and flow from portable flowmeter. Note if the flow or pressure are unstable.

13. From the PLC, continue opening valve MOV305 in $20 \%$ increments and letting run for 5 minutes. Record stabilized pressure from pressure gauge PI305 and flow from portable flowmeter at each increment. Note if any of the flows or pressures are unstable.

14. From the PLC. stop LPP495.

15. Complete checklist 4.4.1 in Appendix A.

16. Repeat test twice.

\subsubsection{High Pressure Pump Test}

The purpose of the high pressure pump test is to verify the high pressure pumps are functioning properly. During this test the pumps will be operated in a recycle mode (Fig. 4.4) and in a strainer flushing mode (Fig. 4.5). For system success. the pumps must develop enough pressure and flow to flush the strainers (nominal), feed the sluicer nozzle (200 gpm at $200 \mathrm{psi}$ ), and transfer waste to MVST ( $50 \mathrm{gpm}$ at $50 \mathrm{psi}$ ). Additionally. the rupture disks must fail at 225-275 psi and the system must alarm on high discharge pressure and on low intake pressure.

\subsubsection{On-line strainer flush test}

The operation of the high pressure pumps during on-line strainer flushing will be evaluated by operating the system in a strainer flushing mode (Fig. 4.5). 


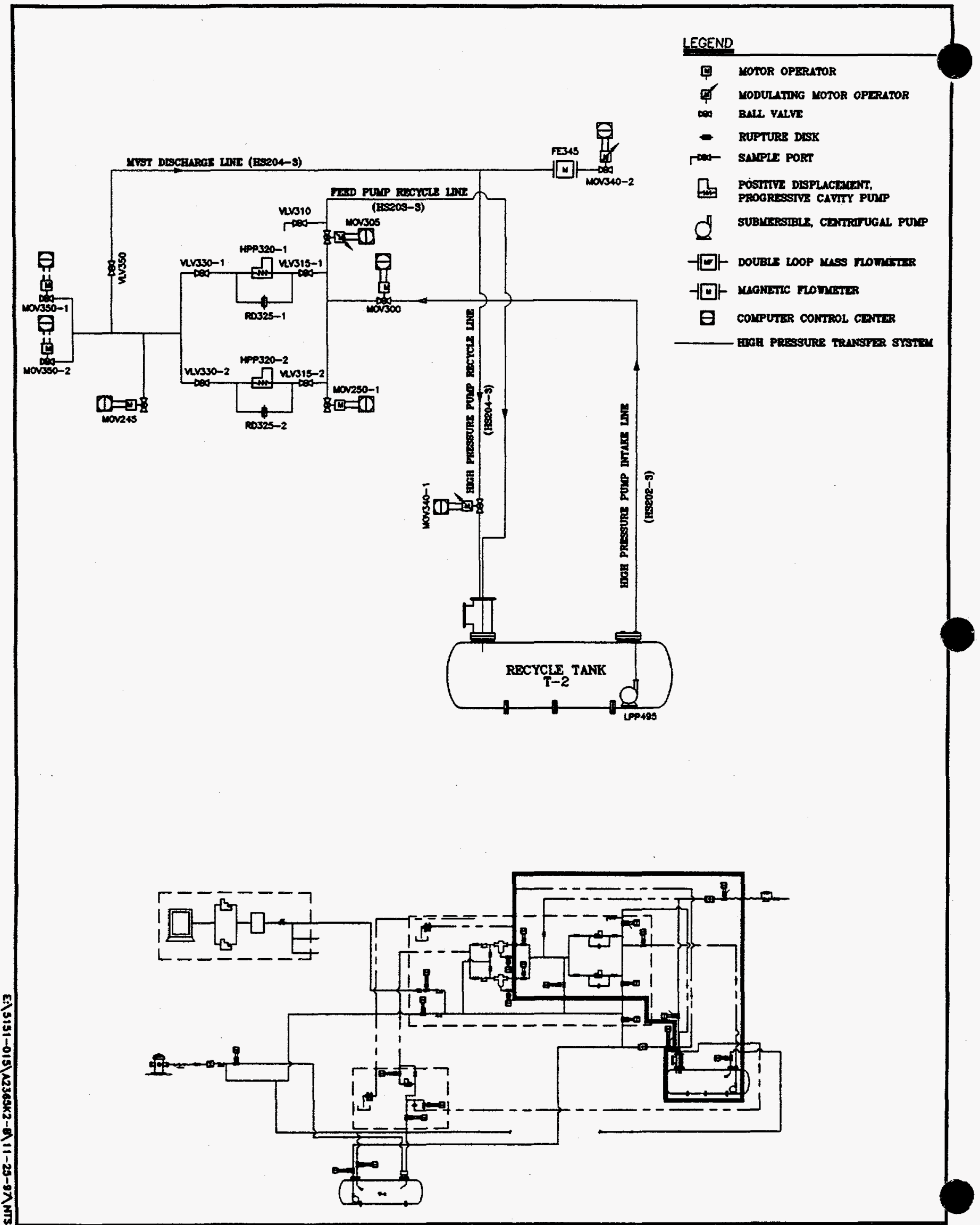




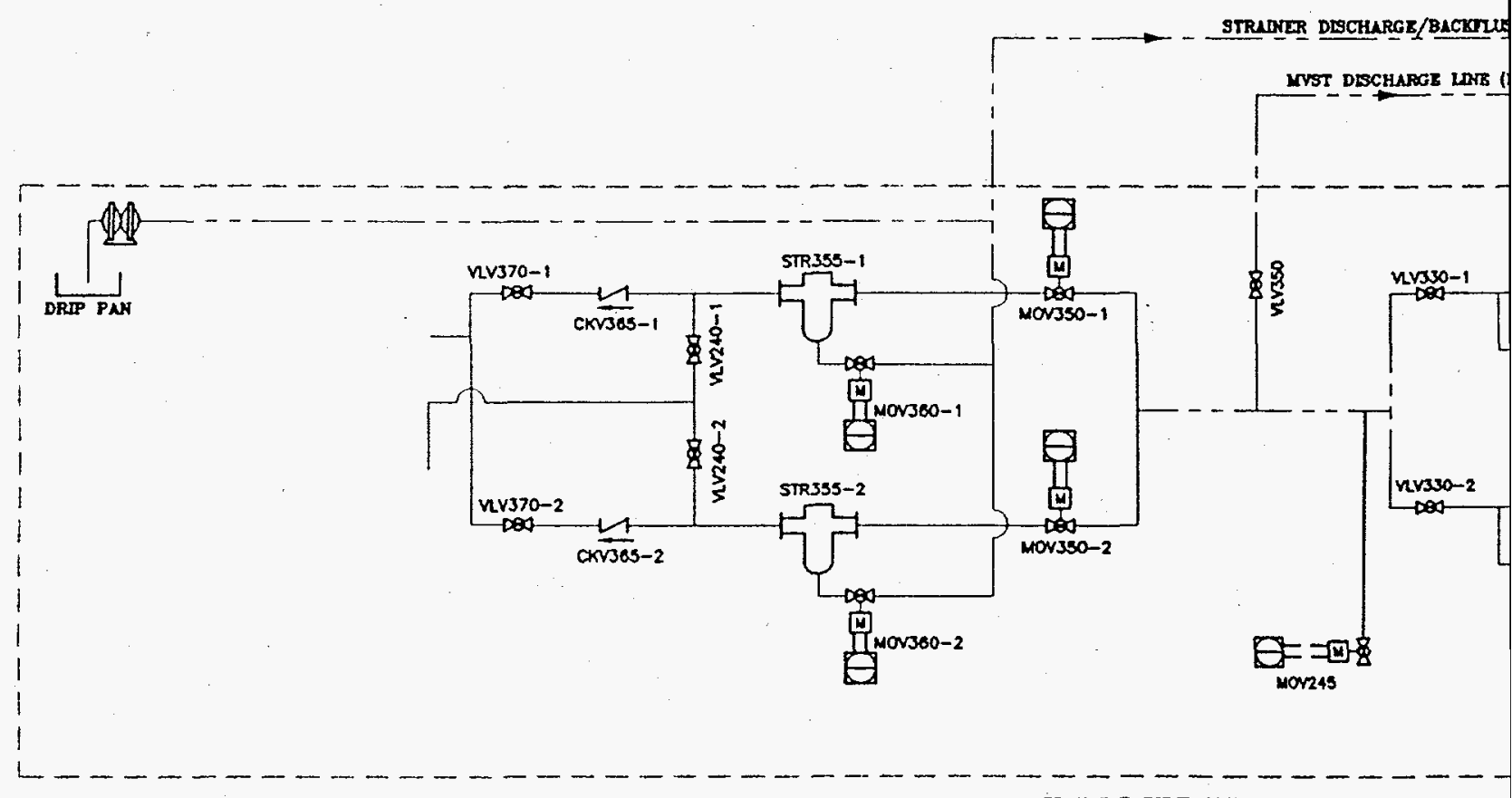

TRAKSTER PUMP SKID 


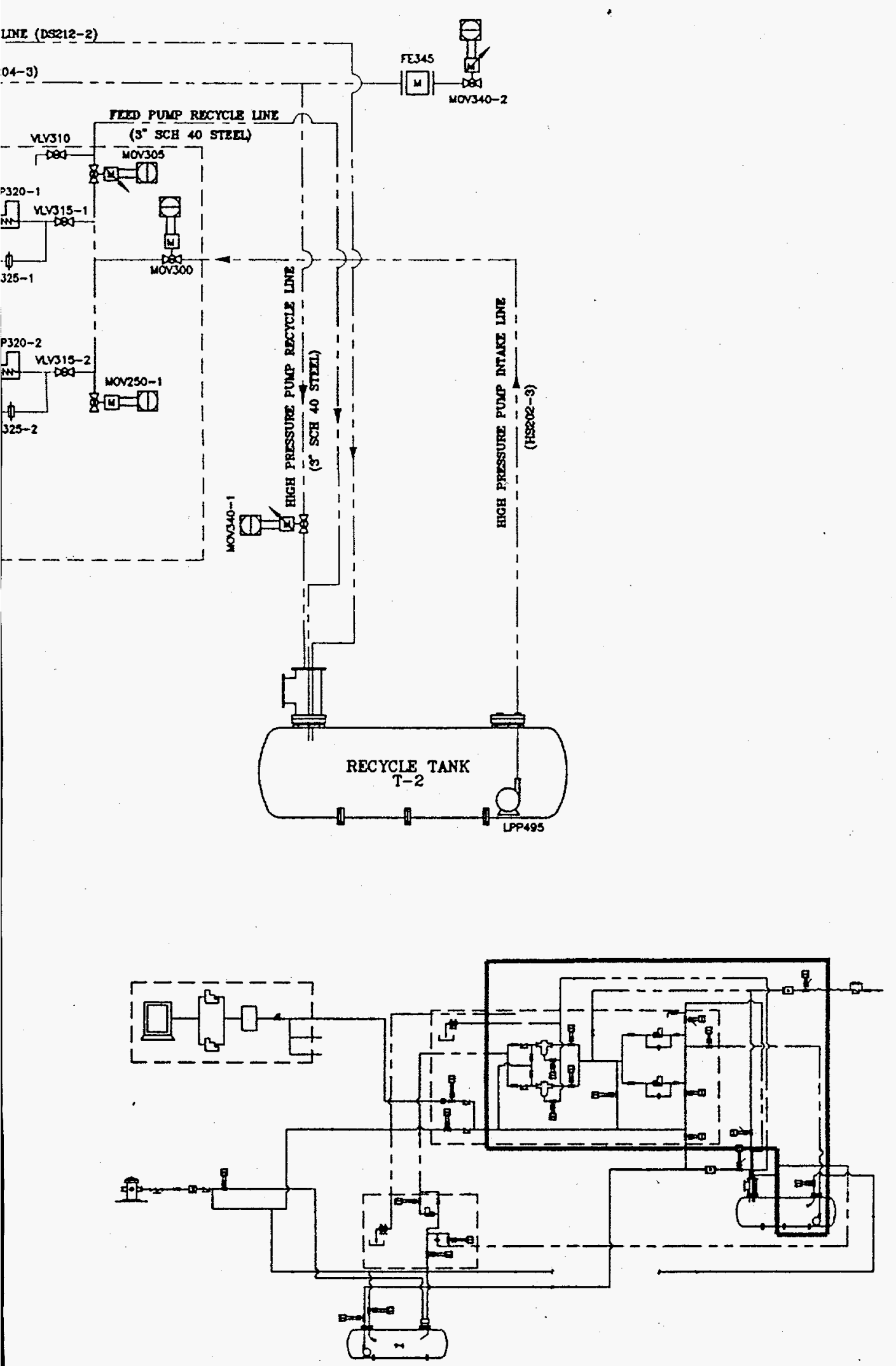

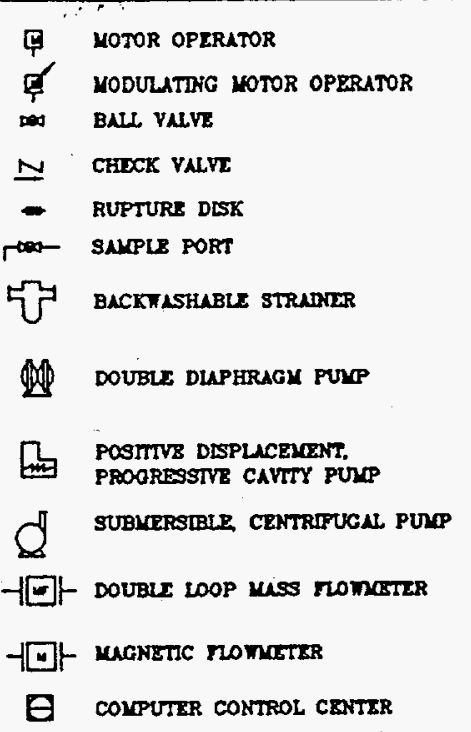


Minimum Personnel Required: Project Engineer to oversee the testing Two system operators to conduct the test

Special Permits: $\quad$ None

Special Equipment: $\quad$ Portable, strap-on flowmeter

Prerequisites: $\quad$ Before this test, the equipment will be set up as described in Chaps. 2 and 3. Additionally, the system must have passed the leak test, the control test, and the submersible pump test. The recycle tank must contain 3400 gal of solids-free water.

Testing Instructions:

1. Verify the local switches for pumps LPP495 and HPP320-1 are in the REMOTE position.

2. Open manual valve VLV315-1 (pump HPP320-1 intake valve).

3. Open manual valve VLV330-1 (pump HPP320-1 discharge valve).

4. Open manual valve VLV350 (high pressure pump recycle valve).

5. Close manual valve VLV240-1 (strainer STR355-1 rinse valve).

6. Close manual valve VLV240-2 (strainer STR355-2 rinse valve).

7. Close manual valve VLV310 (sample port valve).

8. Close manual valve VLV315-2 (pump HPP320-2 intake valve).

9. Close manual valve VLV330-2 (pump HPP320-2 discharge valve).

10. Close manual valve VLV370-1 (strainer STR355-1 isolation valve).

11. Close manual valve VLV370-2 (strainer STR355-2 isolation valve).

12. From the PLC, open actuated valve MOV300 (pump LPP495 discharge valve).

13. From the PLC, set actuated valve MOV305 to 50\% open (pump LPP495 recycle valve).

14. From the PLC, set actuated valve MOV340-1 to $50 \%$ open (high pressure pumps recycle valve).

15. From the PLC, open actuated valve MOV350-1 (strainer STR355-1 inlet valve).

16. From the PLC, close actuated valve MOV245 (process water flush valve).

17. From the PLC, close actuated valve MOV250-1 (recycle tank bypass valve). 
18. From the PLC, close actuated valve MOV340-2 (MVST transfer valve).

19. From the PLC, close actuated valve MOV350-2 (strainer STR355-2 inlet valve).

20. From the PLC, close actuated valve MOV360-1 (strainer STR355-1 flush valve).

21. From the PLC, close actuated valve MOV360-2 (strainer STR355-2 flush valve).

22. Turn on recycle tank camera and aim toward strainer drain line discharge.

23. Attach the portable flowmeter to the strainer drain line (DS212-2).

24. Turn on camera and aim toward discharge lines.

25. From the PLC, start submersible pump LPP495.

26. From the PLC, start high pressure pump HPP320-1 and set to $50 \%$ power.

27. Monitor the high pressure pump intake pressure (PI320-1A). If pressure goes too low, adjust MOV305 (pump LPP495 recycle valve).

28. Check camera for discharge into tank from high pressure recycle line.

29. From the PLC, open actuated valve MOV360-1 (strainer STR355-1 drain valve).

30. Record flow rate from portable flowmeter.

31. From the PLC, close actuated valve MOV360-1 (strainer STR355-1 drain valve).

32. From the PLC, close actuated valve MOV350-1 (strainer STR355-1 inlet valve).

33. From the PLC, open actuated valve MOV350-2 (strainer STR355-2 inlet valve).

34. From the PLC, open actuated valve MOV360-2 (strainer STR355-2 drain valve).

35. Record flow rate from portable flowmeter.

36. From the PLC, close actuated valve MOV360-2 (strainer STR355-2 drain valve).

37. From the PLC, close actuated valve MOV350-2 (strainer STR355-2 inlet valve).

38. From the PLC, stop high pressure pump HPP320-1.

39. From the PLC, stop submersible pump LPP495.

40. Complete checklist 4.4.2.1 in Appendix A. 


\subsubsection{Pump HPP320-1 test}

The performance of the high pressure pumps will be evaluated by operating the recycle tank submersible pump and the high pressure pumps in a recirculation mode using supernatant (Fig. 4.4). For system success, the pumps must develop enough pressure and flow to feed the sluicer nozzle (200 gpm at $200 \mathrm{psi}$ ) and to transfer waste to MVST (50 gpm at $50 \mathrm{psi}$ ). Additionally, the rupture disks must fail at $250 \mathrm{psi} \pm 10 \%$ and the system must alarm on high discharge pressure and on low intake pressure.

Minimum Personnel Required: Project Engineer to oversee the testing

Two system operators to conduct the test

Special Permits: None

Special Equipment: $\quad$ Portable, strap-on flowmeter

Prerequisites: $\quad$ Before this test, the equipment will be set up as described in Chaps. 2 and 3 . Additionally, the system must have passed the leak test, the control test, and the submersible pump test. The recycle tank must contain 3400 gal of solids-free water.

Testing Instructions:

1. Verify the local switches for pumps LPP495 and HPP320-1 are in the REMOTE position.

2. Open manual valve VLV315-1 (pump HPP320-1 intake valve).

3. Open manual valve VLV330-1 (pump HPP320-1 discharge valve).

4. Open manual valve VLV350 (high pressure pump recycle valve).

5. Close manual valve VLV310 (sample port valve).

6. Close manual valve VLV315-2 (pump HPP320-2 intake valve).

7. Close manual valve VLV330-2 (pump HPP320-2 discharge valve).

8. From the PLC, open actuated valve MOV300 (pump LPP495 discharge valve).

9. From the PLC, set actuated valve MOV305 to 50\% open (pump LPP495 recycle valve).

10. From the PLC, set actuated valve MOV340-1 to $50 \%$ open (high pressure pumps recycle valve).

11. From the PLC, close actuated valve MOV350-1 (strainer STR355-1 inlet valve).

12. From the PLC, close actuated valve MOV245 (process water flush valve).

13. From the PLC, close actuated valve MOV250-1 (recycle tank bypass valve). 
14. From the PLC, close actuated valve MOV340-2 (MVST transfer valve).

15. From the PLC, close actuated valve MOV350-2 (strainer STR355-2 inlet valve).

16. Turn on recycle tank camera and aim toward high pressure pump recycle line discharge.

17. Attach the portable flowmeter to the high pressure pump recycle line (HS204-3).

18. From the PLC, start pump LPP495.

19. From the PLC, start high pressure pump HPP320-1 and set to $25 \%$ power.

20. Monitor the high pressure pump intake pressure (PI305-1A). If pressure goes too low, adjust MOV305 (pump LPP495 recycle valve).

21. Verify ability of pump HPP320-1 ability to transfer waste to the MVST by adjusting the pump speed and valve MOV340-1 (high pressure pump recycle valve) until portable flowmeter reads $50 \mathrm{gpm}$ and PI330 (high pressure pumps discharge pressure) reads $50 \mathrm{psi}$.

22. Visually inspect the pump for belt slippage and vibration.

23. Allow pump to operate for 5 minutes.

24. Stop high pressure pump HPP320-1.

25. Repeat steps 19 through 24.

26. From the PLC, start high pressure pump HPP320-1 and set to $25 \%$ power.

27. Monitor the high pressure pump intake pressure (P1305). If pressure goes too low, adjust MOV305 (pump LPP495 recycle valve).

28. Verify ability of pump HPP320-1 to feed the sluicer nozzle by adjusting the pump speed and valve MOV340-1 (high pressure pump recycle valve) until portable flowmeter reads $200 \mathrm{gpm}$ and PI330 (high pressure pumps discharge pressure) reads $200 \mathrm{psi}$.

29. Visually inspect the pump for belt slippage and vibration.

30. Allow pump to operate for 5 minutes.

31. Stop high pressure pump HPP320-1.

32. Repeat steps 26 through 31 .

33. From the PLC, set actuated valve MOV340-1 (high pressure pump recycle valve) to $50 \%$ open.

34. From the PLC, start high pressure pump HPP320-1 and set to $25 \%$ power. 
35. Record pressures from PI305 (high pressure pumps intake pressure). PI330 (high pressure pumps discharge pressure), and the flow from the portable flowmeter.

36. Visually inspect pump HPP320-1 for vibration and belt slippage.

37. From the PLC, close valve actuated MOV305 (pump LPP495 recycle valve).

38. From the PLC, stop pump LPP495 while observing PI305 (high pressure pumps intake pressure). The PLC should alarm and shut down pump HPP320-1 on low intake pressure at 5 psi.

39. From the PLC, open actuated valve MOV305 (pump LPP495 recycle valve) to $50 \%$.

40. From the PLC, start pump LPP495.

41. From the PLC, start pump HPP320-1 at 50\% power.

42. Record pressures from PI305 (high pressure pumps intake pressure), PI330 (high pressure pumps discharge pressure), and the flow from the portable flowmeter.

43. Inspect HPP320-1 for vibration and belt slippage.

44. Repeat steps 42 and 43 for pump HPP320-1 at $75 \%$ and $100 \%$ power.

45. From the PLC, slow pump HPP $320-1$ to $75 \%$ power.

46. From the PLC, slowly close MOV340-1 until PI330 (high pressure pumps discharge pressure) reads 215 psi. At this point, the PLC should alarm.

47. From the PLC, slowly close MOV340-1 until PI330 (high pressure pumps discharge pressure) reads 225 psi. At this point, the PLC should alarm and shut down both pumps.

48. Disable high pressure switch PSH320-1 (pump HPP320-1 discharge pressure switch).

49. From the PLC, open MOV340-1 to $50 \%$.

50. From the PLC, start pump LPP495.

51. From the PLC, start pump HPP320-1 at $75 \%$ power.

52. From the PLC, slowly close MOV340-1 (high pressure pump recycle line) until the differential pressure between PI320-1 A (high pressure pumps intake pressure) and PI330 (high pressure pumps discharge pressure) reaches 275 psi or it drops suddenly. (A pressure drop indicates rupture disk RD325-1 has blown.) Record the differential pressure at which the drop occurs.

53. Stop pumps LPP495 and HPP320-1.

54. Enable high pressure switch PHS320-1 (pump HPP320-1 discharge pressure switch). 
55. Complete checklist 4.4.2.2 in Appendix A.

\subsubsection{Pump HPP320-2 test}

The performance of the high pressure pumps will be evaluated by operating the recycle tank submersible pump and the high pressure pumps in a recirculation mode using supernatant (Fig. 4.4). For system success, the pumps must develop enough pressure and flow to feed the sluicer nozzle (200 gpm at $200 \mathrm{psi}$ ) and to transfer waste to MVST (50 gpm at $50 \mathrm{psi}$ ). Additionally, the rupture disks must fail at $250 \mathrm{psi} \pm 10 \%$ and the system must alarm on high discharge pressure and on low intake pressure.

Minimum Personnel Required: Project Engineer to oversee the testing Two system operators to conduct the test

Special Permits: $\quad$ None

Special Equipment: $\quad$ Portable, strap-on flowmeter

Prerequisites: $\quad$ Before this test, the equipment will be set up as described in Chaps. 2 and 3 . Additionally, the system must have passed the leak test, the control test, and the submersible pump test. The recycle tank must contain 3400 gal of solids-free water.

Testing Instructions:

1. Verify the local switches for pumps LPP495 and HPP320-2 are in the REMOTE position.

2. Open manual valve VLV315-2 (pump HPP320-2 intake valve).

3. Open manual valve VLV330-2 (pump HPP320-2 discharge valve).

4. Open manual valve VLV350 (high pressure pump recycle valve).

5. Close manual valve VLV310 (sample port valve).

6. Close manual valve VLV315-1 (pump HPP320-1 intake valve).

7. Close manual valve VLV330-1 (pump HPP320-1 discharge valve).

8. From the PLC, open actuated valve MOV300 (pump LPP495 discharge valve).

9. From the PLC, set actuated valve MOV305 to 50\% open (pump LPP495 recycle valve).

10. From the PLC, set actuated valve MOV340-1 to $50 \%$ open (high pressure pumps recycle valve).

11. From the PLC, close actuated valve MOV350-1 (strainer STR355-1 inlet valve).

12. From the PLC, close actuated valve MOV245 (process water flush valve). 
13. From the PLC, close actuated valve MOV250-1 (recycle tank bypass valve).

14. From the PLC, close actuated valve MOV340-2 (MVST transfer valve).

15. From the PLC, close actuated valve MOV350-2 (strainer STR355-2 inlet valve).

16. Turn on recycle tank camera and aim toward high pressure pump recycle line discharge.

17. Attach the portable flowmeter to the high pressure pump recycle line (HS204-3).

18. From the PLC, start pump LPP495.

19. From the PLC, start high pressure pump HPP320-2 and set to $25 \%$ power.

20. Monitor the high pressure pump intake pressure (PI305). If pressure goes too low, adjust MOV305 (pump LPP495 recycle valve).

21. Verify pump HPP320-2's ability to transfer waste to the MVST by adjusting the pump speed and valve MOV340-1 (high pressure pump recycle valve) until portable flowmeter reads 50 gpm and PI330 (high pressure pumps discharge pressure) reads 50 psi.

22. Visually inspect the pump for belt slippage and vibration.

23. Allow pump to operate for 5 minutes.

24. Stop high pressure pump HPP320-2.

25. Repeat steps 19 through 24.

26. From the PLC, start high pressure pump HPP320-2 and set to $25 \%$ power.

27. Monitor the high pressure pump intake pressure (PI305). If pressure goes too low, adjust MOV305 (pump LPP495 recycle valve).

28. Verify the pump's ability to feed the sluicer nozzle by adjusting the pump speed and valve MOV340-2 (high pressure pump recycle valve) until portable flowmeter reads $200 \mathrm{gpm}$ and P1330 (high pressure pumps discharge pressure) reads 200 psi.

29. Visually inspect the pump for belt slippage and vibration.

30. Allow pump to operate for 5 minutes.

31. Stop high pressure pump HPP320-2.

32. Repeat steps 26 through 31 .

33. From the PLC, set actuated valve MOV340-1 (high pressure pump recycle valve) to $50 \%$ open.

34. From the PLC, start high pressure pump HPP320-2 and set to $25 \%$ power. 
35. Record pressures from PI305 (high pressure pumps intake pressure), PI330 (high pressure pumps discharge pressure), and the flow from the portable flowmeter.

36. Visually inspect pump HPP320-2 for vibration and belt slippage.

37. From the PLC, close valve actuated MOV305 (pump LPP495 recycle valve).

38. From the PLC, stop pump LPP495 while observing PI305 (high pressure pumps intake pressure). The PLC should alarm and shut down pump HPP320-1 on low intake pressure at 5 psi.

39. From the PLC, open actuated valve MOV305 (pump LPP495 recycle valve) to $50 \%$.

40. From the PLC, start pump LPP495.

41. From the PLC, start pump HPP320-2 at 50\% power.

42. Record pressures from PI305 (high pressure pumps discharge pressure), PI330 (high pressure pumps discharge pressure), and the flow from the portable flowmeter.

43. Inspect HPP320-2 for vibration and belt slippage.

44. Repeat steps 42 and 43 for pump HPP $320-2$ at $75 \%$ and $100 \%$ power.

45. From the PLC, slow pump HPP320-2 to $75 \%$ power.

46. From the PLC, slowly close MOV340-1 until PI330 (high pressure pumps discharge pressure) reads 215 psi. At this point, the PLC should alarm.

47. From the PLC, slowly close MOV340-1 until PI330 (high pressure pumps discharge pressure) reads 225 psi. At this point, the PLC should alarm and shut down both pumps.

48. Disable high pressure switch PSH320-1 (pump HPP320-2 discharge pressure switch).

49. From the PLC, open MOV $340-1$ to $50 \%$.

50. From the PLC, start pump LPP495.

51. From the PLC, start pump HPP320-2 at $75 \%$ power.

52. From the PLC, slowly close MOV340-1 (high pressure pump recycle line) until the differential pressure between PI305 (high pressure pumps intake pressure) and PI330 (high pressure pumps discharge pressure) reaches $275 \mathrm{psi}$ or it drops suddenly. (A pressure drop indicates rupture disk RD325-2 has blown.) Record the differential pressure at which the drop occurs.

53. Stop pumps LPP495 and HPP320-2.

54. Enable high pressure switch PHS320-2 (pump HPP320-2 discharge pressure switch). 
55. Complete checklist 4.4.2.3 in Appendix A.

\subsubsection{High pressure pump reset}

During testing of the high pressure pumps (Sects. 4.4.2.2 and 4.4.2.3), the high pressure pump rupture disks will be blown and the high pressure switched temporarily disabled. The purpose of the high pressure pump reset is to replace the blown rupture disks and to verify the pressure switches are operating correctly after being temporarily disabled. Valves referenced in this test are shown in Fig. 4.4.

Minimum Personnel Required: Project Engineer to oversee the testing

Two system operators to conduct the test

Special Permits: $\quad$ Lockout/tagout for rupture disk replacement

Special Equipment: $\quad$ Miscellaneous hand tools, two replacement rupture disks, and portable, strap-on flowmeter

Prerequisites: $\quad$ Before this reset, both high pressure pump tests must be completed and the recycle tank must contain 3400 gal of solidsfree water.

Resêt Instructions:

1. Replace rupture disks RD325-1 and RD325-2 by the method described in Work Instruction 13 Rupture Disk Replacement.

2. Turn the local switches for pumps LPP495, HPP320-1, and HPP320-2 to the REMOTE position.

3. Open manual valve VLV315-1 (pump HPP320-1 intake valve).

4. Open manual valve VLV330-1 (pump HPP320-1 discharge valve).

5. Open manual valve VLV350 (high pressure pump recycle valve).

6. Close manual valve VLV310 (sample port valve).

7. Close manual valve VLV315-2 (pump HPP320-2 intake valve).

8. Close manual valve VLV330-2 (pump HPP320-2 discharge valve).

9. From the PLC, open actuated valve MOV300 (pump LPP495 discharge valve).

10. From the PLC, set actuated valve MOV305 to 50\% open (pump LPP495 recycle valve).

11. From the PLC, set actuated valve MOV340-1 to $50 \%$ open (high pressure pumps recycle valve). 
12. From the PLC, close actuated valve MOV350-1 (strainer STR355-1 inlet valve).

13. From the PLC, close actuated valve MOV245 (process water flush valve).

14. From the PLC, close actuated valve MOV250-1 (recycle tank bypass valve).

15. From the PLC, close actuated valve MOV340-2 (MVST transfer valve).

16. From the PLC, close actuated valve MOV350-2 (strainer STR355-2 inlet valve).

17. From the PLC, start pump LPP495.

18. From the PLC, set pump HPP $320-1$ to $75 \%$ power.

19. From the PLC, slowly close MOV340-1 until PI330 (high pressure pumps discharge pressure) reads 215 psi. At this point, the PLC should alarm.

20. From the PLC, slowly close MOV340-1 until PI330 (high pressure pumps discharge pressure) reads 225 psi. At this point, the PLC should alarm and shut down both pumps.

21. Close manual valve VLV315-1 (pump HPP320-1 intake valve).

22. Close manual valve VLV330-1 (pump HPP320-1 discharge valve).

23. Open manual valve VLV315-2 (pump HPP320-2 intake valve).

24. Open manual valve VLV330-2 (pump HPP320-2 discharge valve).

25. From the PLC, start pump LPP495.

26. From the PLC, set pump HPP320-2 to $75 \%$ power.

27. From the PLC, slowly close MOV340-1 until PI330 (high pressure pumps discharge pressure) reads 215 psi. At this point, the PLC should alarm.

28. From the PLC, slowly close MOV340-1 until PI330 (high pressure pumps discharge pressure) reads 225 psi. At this point. the PLC should alarm and shut down both pumps.

55. Complete checklist 4.4.2.4 in Appendix A.

\subsubsection{Sluicer Pump Test}

The performance of the sluicer pump will be evaluated by operating the complete system in a sluicing mode with the submersible pump in the sluice tank (LPP410-2) raised above the sludge (Fig. 4.6). For system success, the pump must sustain operating pressure of 1500 psi. not have excessive vibration or belt slippage, and start/stop upon command from the PLC. Additionally, the PLC must alarm on low pump intake pressure. Details of the test are as follows: 


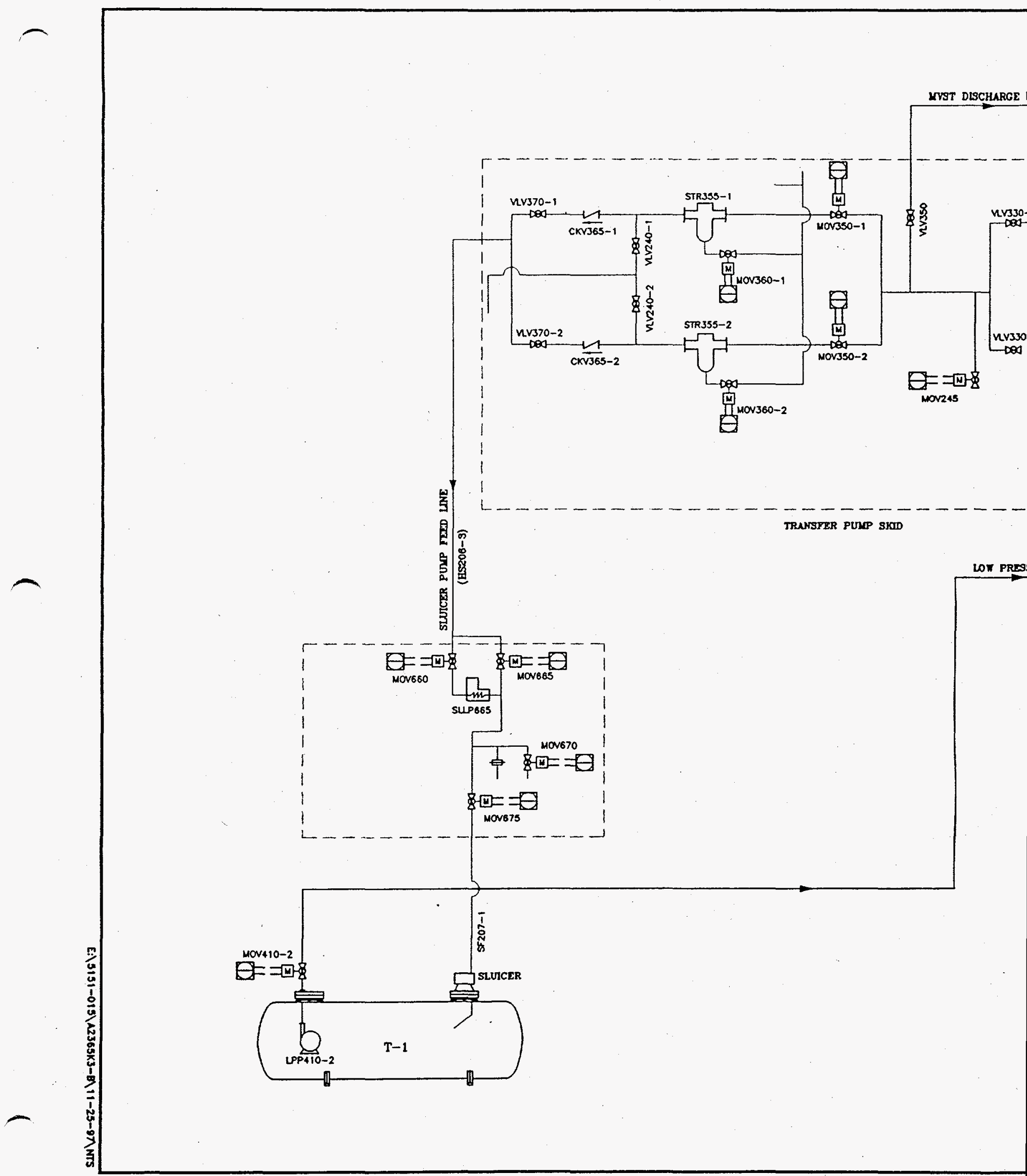

\section{CDII}




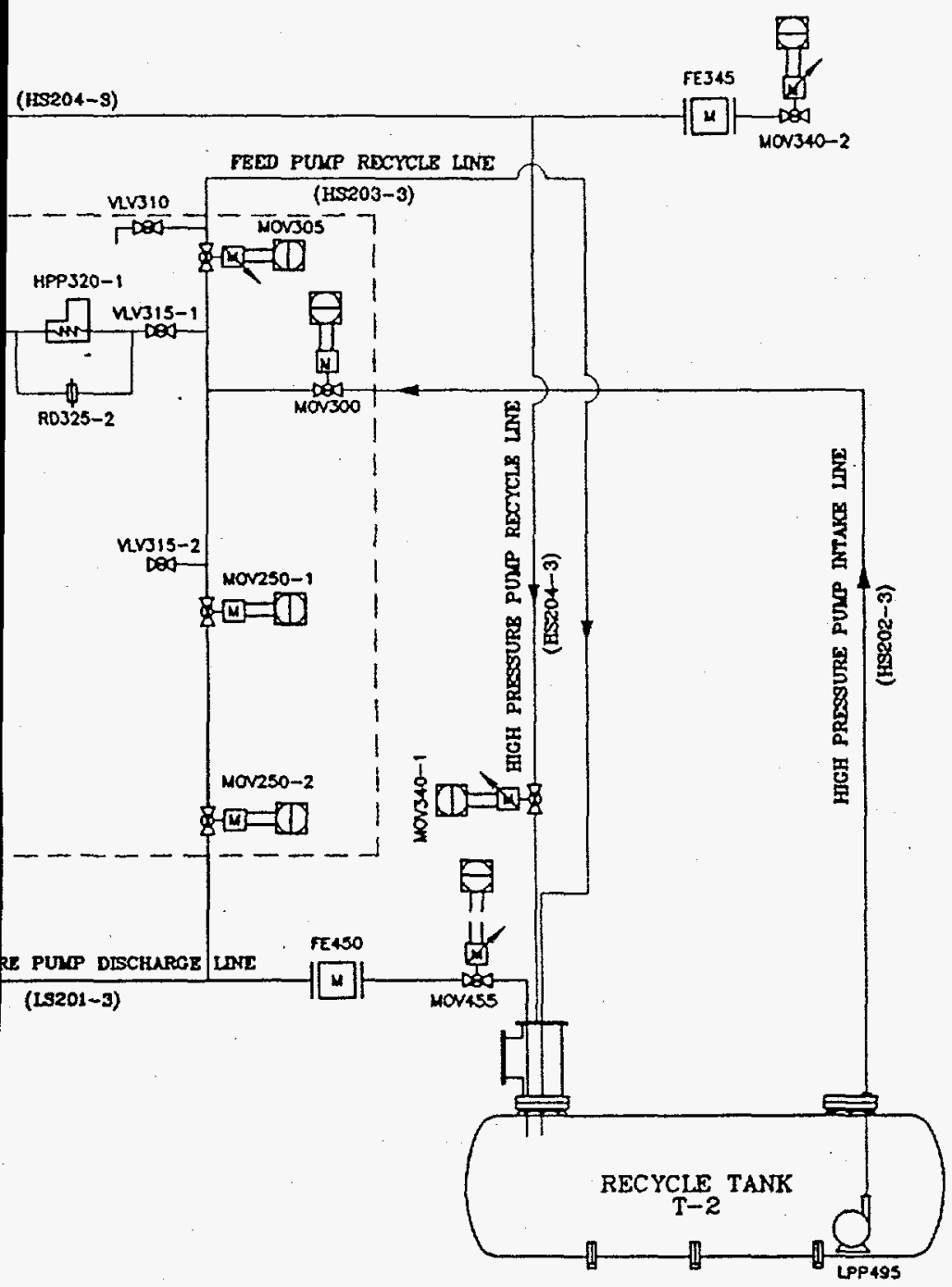

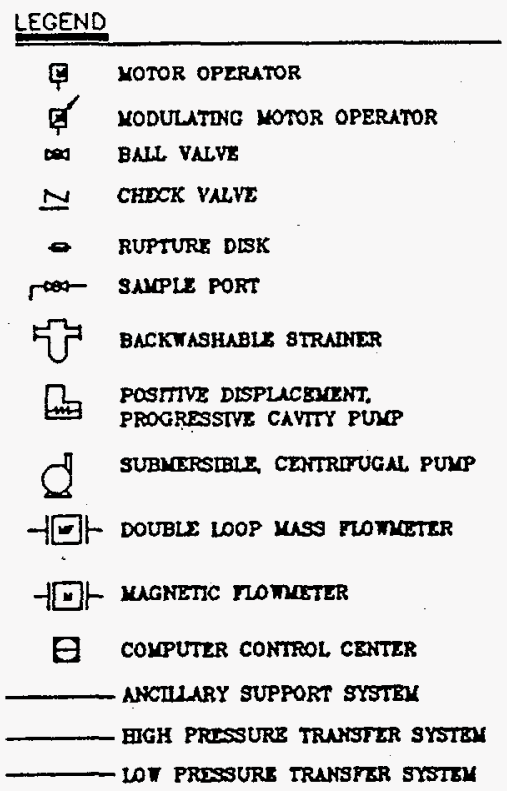

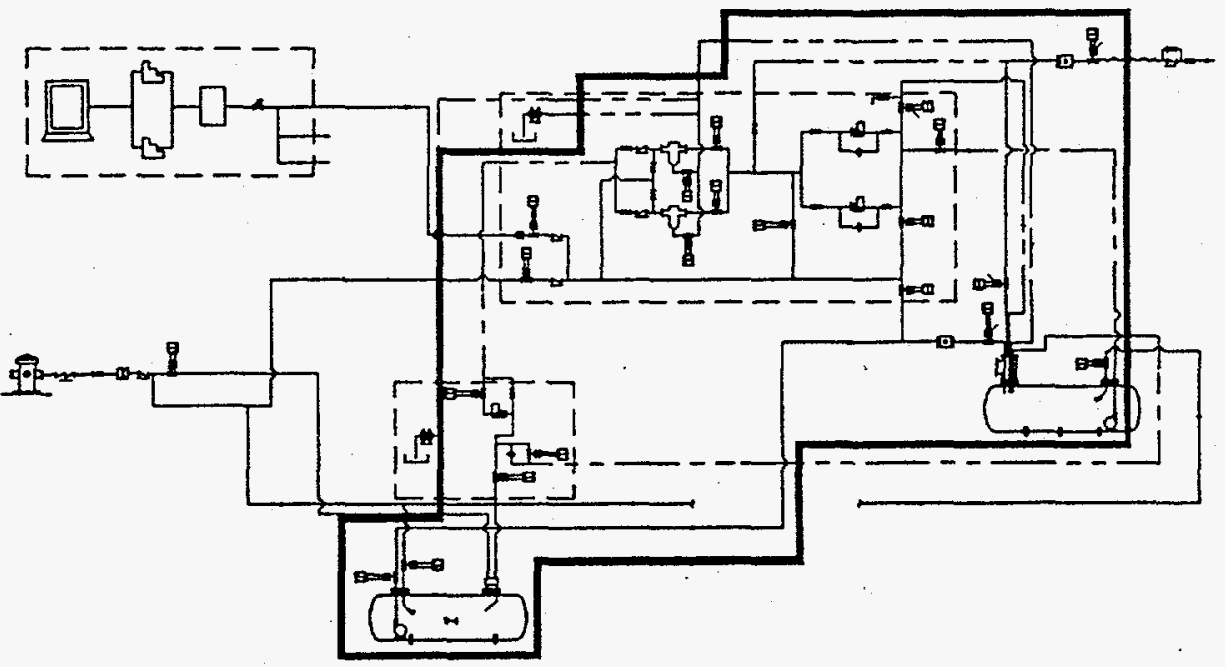

Fig. 4.6. Sluicer pump test

Oak Ridge National Laboratory Old Hydrofracture Tank Contents Removal Project 
Minimum Personnel Required: Project Engineer to oversee the testing

Two system operators to conduct the test

Special Permits: None

Special Equipment: None

Prerequisites:

Before this test, the equipment will be set up as described in Chaps. 2 and 3 . Additionally, the system must have passed the leak test, the control test, the submersible pump test, and the high pressure pump test. The recycle tank must contain $3400 \mathrm{gal}$ of solids-free water. The sluice tank must contain 3000 gal of water and 4.7 tons of kaolin clay. Additionally, the material in the sluice tank must be separated into distinct supernatant and sludge layers.

Testing Instructions:

1. Verify the local switches for pumps LPP410-2, LPP495, HPP320-1, and SLCP665 are in the REMOTE position.

2. Open manual valve VLV315-1 (pump HPP320-1 intake valve).

3. Open manual valve VLV330-1 (pump HPP320-1 discharge valve).

4. Open manual valve VLV350 (high pressure pump recycle valve).

5. Open manual valve VLV370-1 (strainer STR355-1 isolation valve) and VLV370-2 (strainer STR355-2 isolation valve).

6. Close manual valve VLV315-2 (pump HPP320-2 intake valve).

7. Close manual valve VLV330-2 (pump HPP320-2 discharge valve).

8. Close manual valve VLV310 (sample port valve).

9. Close manual valve VLV240-1 (strainer STR355-1 flush valve).

10. Close manual valve VLV240-2 (strainer STR355-2 flush valve).

11. From the PLC, open actuated valve MOV300 (pump LPP495 discharge valve).

12. From the PLC, set actuated valves MOV305 (low pressure pump recycle valve) and MOV340-1 (high pressure pump recycle valve) to $50 \%$ open.

13. From the PLC, open actuated valve MOV350-1 (strainer STR355-1 inlet valve).

14. From the PLC, open actuated valve MOV660 (sluicer pump intake valve). 
15. From the PLC, open actuated valve MOV675 (sluicer pump discharge valve).

16. From the PLC, open actuated valve MOV410-2 (pump LPP410-2 discharge valve).

17. From the PLC, close actuated valve MOV250-1 (recycle tank bypass valve).

18. From the PLC, close actuated valve MOV245 (line flush valve).

19. From the PLC, close actuated valve MOV250-2 (recycle tank bypass valve).

20. From the PLC, close actuated valve MOV340-2 (MVST discharge valve).

21. From the PLC, close actuated valve MOV350-2 (strainer STR355-2 inlet valve).

22. From the PLC, close actuated valve MOV360-1 (strainer STR355-1 drain valve).

23. From the PLC, close actuated valve MOV360-2 (strainer STR355-2 drain valve).

24. From the PLC, close actuated valve MOV455 (low pressure transfer pump throttle valve).

25. From the PLC, close actuated valve MOV665 (sluicer bypass valve).

26. From the PLC, close actuated valve MOV670 (sluicer pressure relief valve).

27. Turn on sluicing tank and recycle tank cameras.

28. Start hydraulic power unit.

29. Move the sluicer arm so that the nozzle is aimed at the end of the tank and above the water line.

30. From the PLC, start pump LPP495.

31. From the PLC, start pump HPP320 and set to $50 \%$ power.

32. With one operator watching the sluicer with the sluice tank camera and one operator monitoring the PI663 (sluicer pump intake pressure), start the sluicer pump (SLCP665) at the lowest setting ( $25 \%$ power). Make note of the reaction of sluicer mast to pump startup.

33. Carefully watch the sluicer pump intake pressure and adjust pump HPP320-l's speed and valve MOV340-1 (high pressure pump recycle valve) as needed to maintain pressure above 20 psi.

34. From the PLC, start pump LPP410-2.

35. From the PLC, set valve MOV455 (low pressure transfer throttle valve) to $20 \%$.

36. Carefully watch the level in the sluice tank and adjust valve MOV455 as needed to maintain a relatively uniform tank level. 
37. Record the flow from FE450 (low pressure transfer flowmeter) at which uniform tank level is reached.

38. Visually inspect the sluicer pump for vibration and belt slippage.

39. From local pressure gauges, record the range of pressure swing in PI330 (high pressure pumps discharge pressure) and in PI663 (sluicer pump intake pressure).

40. Repeat steps 33 and 35 through 39 for the sluicer pump (SLCP665) set to 50\%, 75\%, and 100\% power.

41. From the PLC, stop pump LPP410-2.

42. From the PLC, stop pump SCLP665.

43. From the PLC, stop pump HPP320-1.

44. From the PLC, stop pump LPP495.

45. Retract the sluicer arm into the sluicer mast.

46. Shut down the hydraulic power unit.

47. Complete checklist 4.4 .3 in Appendix A.

\subsection{SLUDGE PUMPING TEST}

The testing described in previous sections will have evaluated the systems operation while pumping clean water. The sludge pumping test will evaluate the ability of the system to perform while transferring a water and solids mixture (slurry).

\subsubsection{Low Pressure Pumping Test}

The low pressure pumping test will evaluate the ability of the submersible pumps to operate in undiluted sludge. During this test, only the low pressure transfer system will be operated (Fig. 4.7). For system success, the pump must operate without locking and without excessive jumping. Details of the test are as follows:

Minimum Personnel Required: Project Engineer to oversee the testing System operator to conduct the test

I\&C Engineer

Special Permits: $\quad$ None

Special Equipment: None 


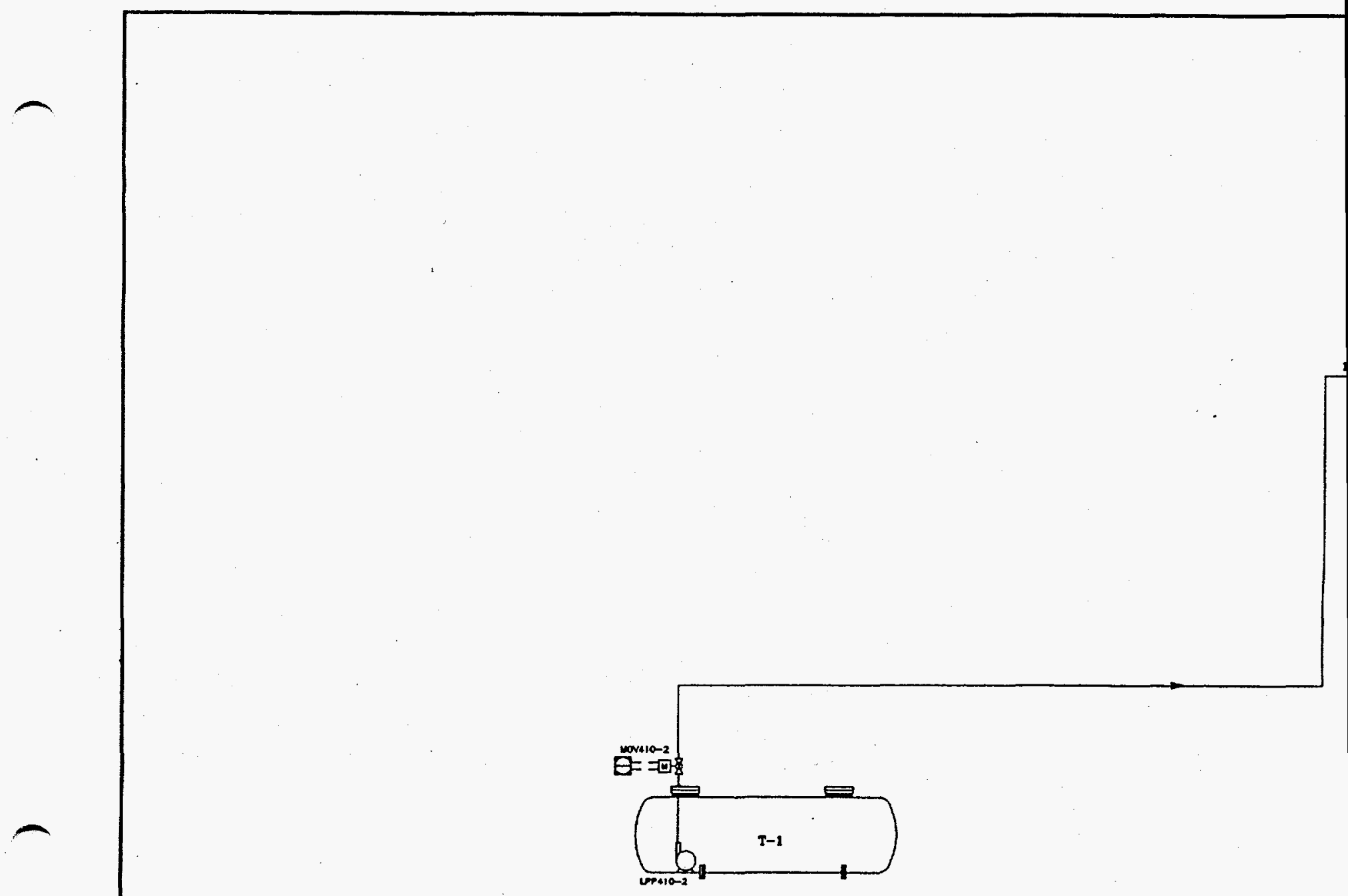


Bar

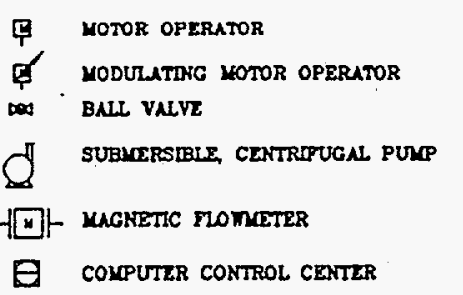
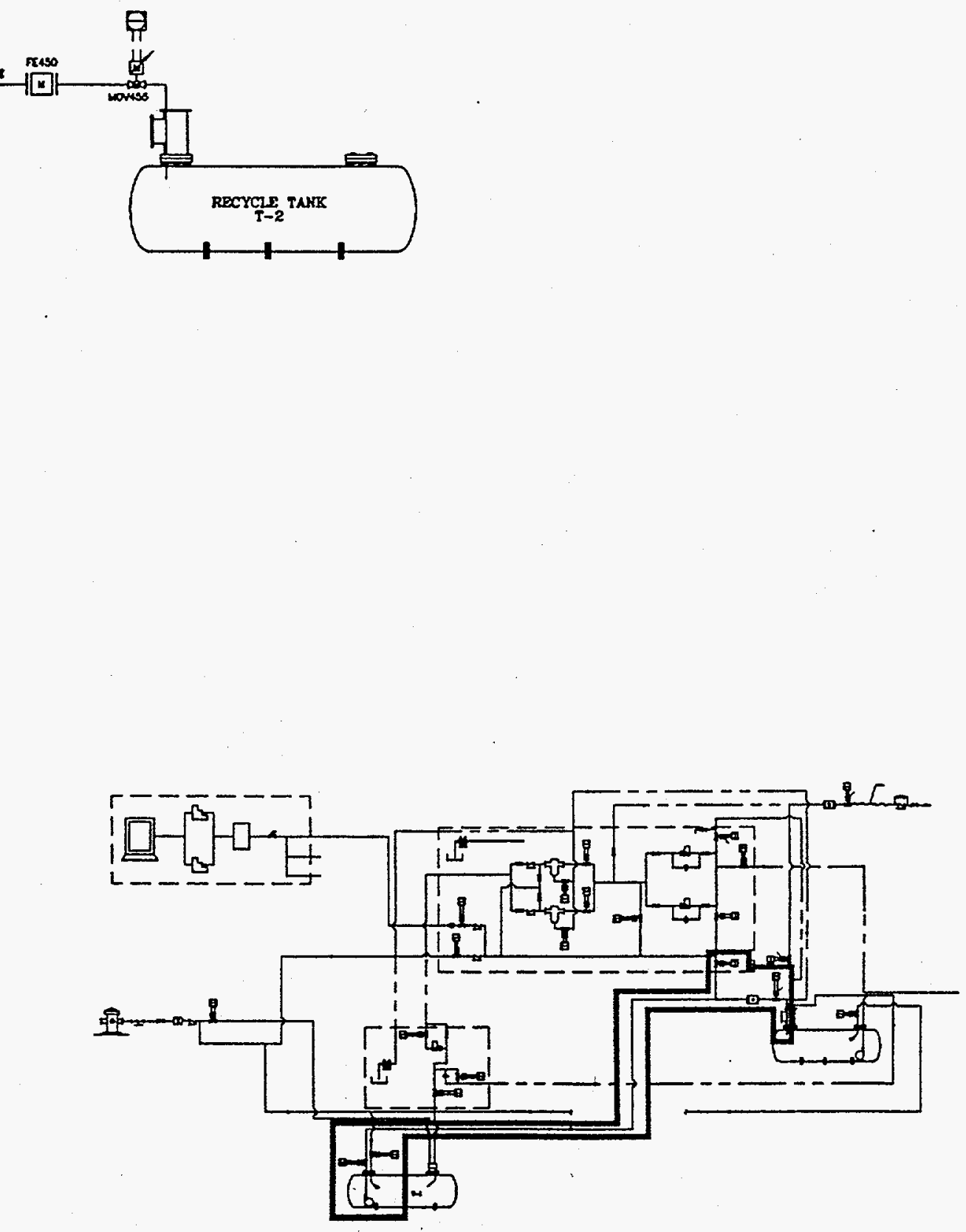

Fig. 4.7. Sludge pumping test

Oak Ridge National Laboratory

old Hydrofracture Tank Contents Removal Project 
Prerequisites:

Before this test, the system must be installed as described in Chaps. 2 and 3 . The system must have also passed the leak test, control test, and clean water capacity test. The sluice tank must contain 4.7 tons of kaolin clay and no less than 1000 gal of water. The material must be separated into distinct sludge and supernatant layers.

Testing Instructions:

1. Place the local switch for pump LPP410-2 in the off position.

2. Turn on the in-tank cameras, focusing the sluice tank camera on the submersible pump and the recycle tank camera on the discharge lines.

3. While monitoring the pump with the in-tank camera, lower pump LPP410-2 down to the sludge layer, leaving $\sim 2$ in. of slack in the pump cable.

4. From the PLC, close actuated valve MOV250-2 (recycle tank bypass valve).

5. From the PLC, open actuated valve MOV410-2.

6. From the PLC, set actuated valve MOV 455 to $50 \%$ open.

7. Turn the local switch for pump LPP410-2 to REMOTE position.

8. While observing the pump with the sluice tank camera, start pump LPP410-2 from the PLC.

9. Monitor and record pump operation and flow rate through FE450 and the tank cameras.

10. Allow pump to operate 2 minutes.

11. With pump running, slowly lower pump to bottom of tank while monitoring operation and flow rate.

12. Allow pump to run for 5 minutes.

13. Complete checklist 4.5.1 in Appendix A.

\subsubsection{Sluicing Test}

The ability of the system to suspend sludge and pump it in a closed circuit system will be evaluated by operating the complete system in a sluicing mode with the PLC automatically regulating the system (Fig. 4.8). For system success, the system must start/stop on command from the operator at the PLC, must operate reasonably close to set points specified by the operator, must be able to switch strainers without flow interruption. must be able to suspend sludge from the bottom of the tank, and the PLC must be able to maintain a system balance. This test will only establish the ability of the system to suspend and pump sludge: the optimal settings for system efficiency will be determined during operator training (see Sect. 4.6). Details of the test are as follows: 


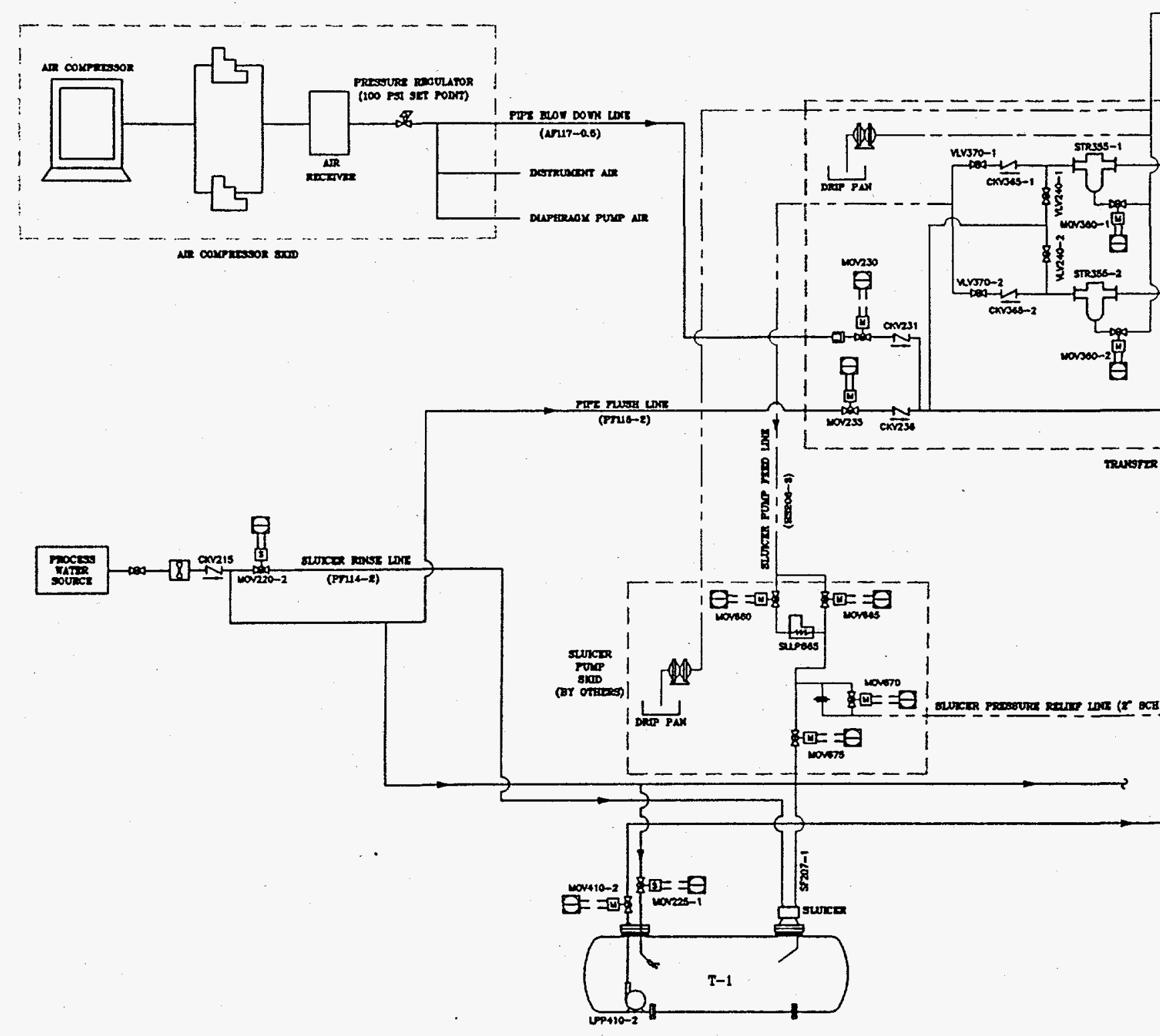




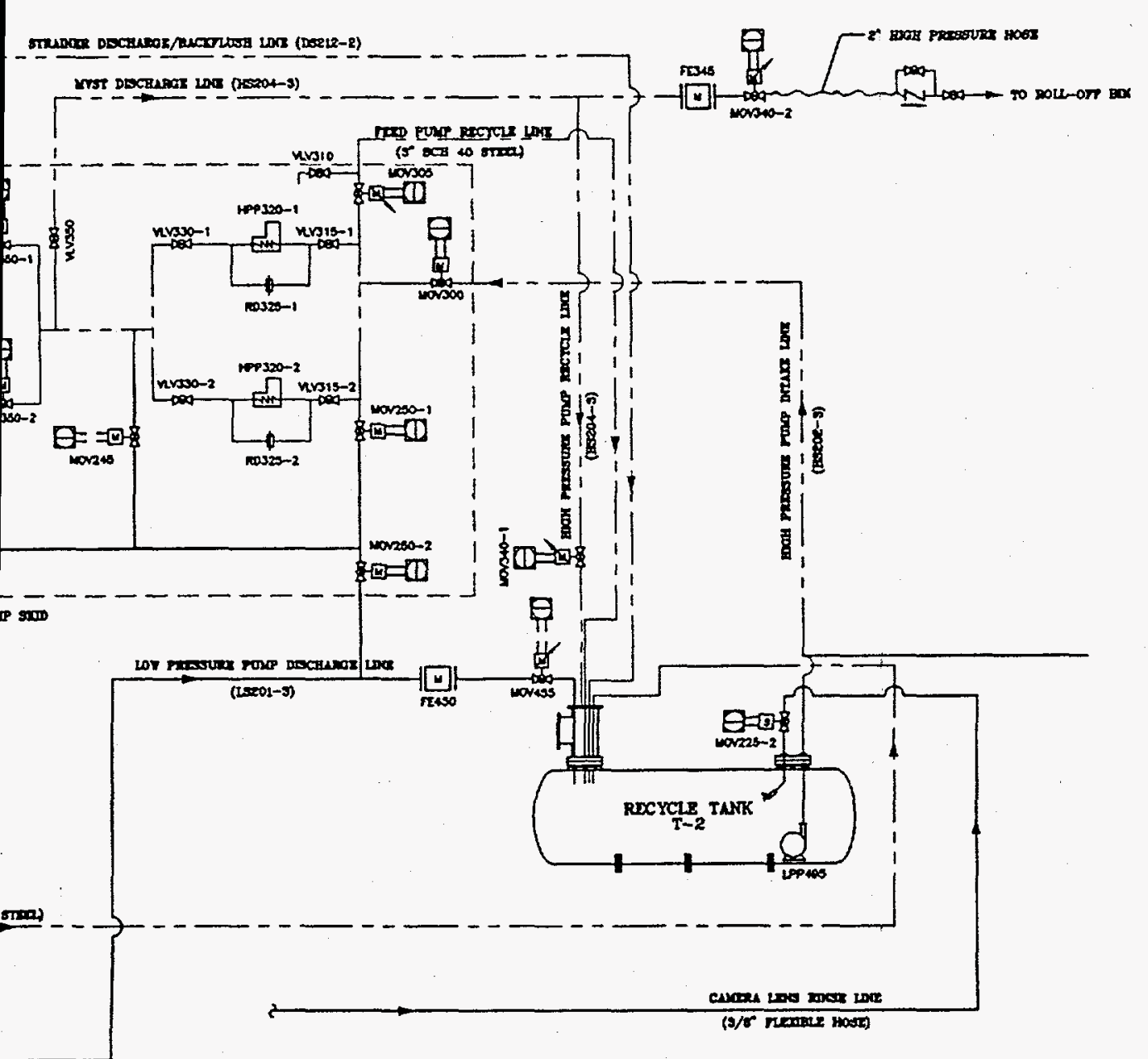

() SOLEHOD OPERATOR

무 KOTOR OPERATOR

D. MODULUTING WOTOR OPERATOR

$\infty$ BuLL VALVE

居 PRESSURE RECULATOR

N CHLCK VALVE

ב- QUICK CONNDCTOR

D DN-TANK YIDEO CAMERA

च PRESSURE RBDUCING BACK-

TLN PREVENTO

- RUPTURE DISK

roo- SAMPIE PORT

F BACKMASHABL STRUNER

DOUELI DUPHRAGK PUMP

C POSITTE DISPLLCEMENT. PROGRESTIE CAYTTY PUTR

d SURMERSTBLE, CENTRIRUALL PUNTP

-1 - DOURLE LOOP XUSS FLONCETER

-

- 8 - PROPEUER FOWXTER

E cOLPUTER CONTROL CENTER

[ ATR COUPPESSOR

亿 AR DRYER

AHCULARY SUPPORT STSTEI HIGH PRESSURB TRMHSTER SYSTEM LOT PRMSSURE TRAMSTER SYSTEN 
Minimum Personnel Required: Project Engineer to oversee the testing

Two system operators to conduct the test

Special Permits: None

Special Equipment: None

Prerequisites: $\quad$ Before this test, the system must be set up as described in Chaps. 2 and 3. The system must have successfully completed the system leak test, control test, clean water capacity test, support systems test, and sludge pumping test.

Testing Instructions:

1. Sluice tanks by method described in Work Instruction 1 (Appendix B). Sluice by beginning underneath the sluicer and working in a side-to-side pattern to the end of the tank.

2. At the completion of the sluicing pass, shut down the sluicing system, transfer as much material as possible to the recycle tank, and videotape the results with the sluice tank camera.

3. Restart the sluicing system and transfer as much of the contents of the recycle tank to the sluice tank as possible.

4. Shut down the system by the method in Work Instruction 7 - Normal System Shutdown (Appendix B).

5. Complete checklist 4.5.2 in Appendix A.

\subsection{OPERATOR TRAINING}

Sluicing system operators will be trained in performing routine operations, emergency operations, and maintenance. Training will consist of a short class on the sluicing system and its operation followed by mock operations at the TTCTF. The conditions during this training will mimic the expected OHF site conditions as closely as possible and will include mock exclusion zones. Operator competency will be demonstrated by response drills and written exams. Training, drills, and exams will be administered by the lead engineer.

Before initiation of project-specific training, operators will receive Energy Systems general employee training, photo badging, respirator awareness, and lockout/tagout training.

\subsubsection{Routine Startup, Operation, and Shutdown}

Sluicing system operators will practice startup, operation, and shutdown of the sluicing system during the cold test. During this practice, various flow rates, pressures, and sluicing patterns will be tried to determine the most efficient sluicing method and to familiarize the operators with the system. 
Minimum Personnel Required: Three system operators

Special Permits: $\quad$ None

Special Equipment: None

Prerequisites: Before this test, the system must be set up as described in Chaps. 2 and 3. The system must have successfully completed the system tests described in Sects. 4.1 through 4.5.

Testing Instructions:

1. Sluice tanks by method described in Work Instruction 1 - Sluicing System Startup (Appendix B).

2. Transfer as much of the waste as possible to the sluice tank (T1) or the roll-off bin.

3. Shut down the system by the method described in Work Instruction 7 - Normal System Shutdown (Appendix B).

\subsubsection{Strainer Clogging}

Sluicing system operators will practice responding to abnormal and emergency conditions during the cold test. The practice will include responding to three types of strainer clogging: (1) slow clogging that can be cleared on-line, (2) slow clogging that cannot be cleared on-line, and (3) rapid clogging.

Minimum Personnel Required: Two system operators and one I\&C engineer

Special Permits: $\quad$ None

Special Equipment: None

Prerequisites:

Before this test, the system must be set up as described in Chaps. 2 and 3 . The system must have successfully completed the system tests described in Sects. 4.1 through 4.5 and the operators must have completed the training outlined in Sect. 4.6.1.

Testing Instructions:

Slow Clogging: Clearable

1. Begin sluicing tanks by method described in Work Instruction 1 (Appendix B).

2. Over a period of several minutes, partially close the isolation valve for the strainer being operated (VLV370-1 or VLV370-2). The valve should be closed until the PLC alarms.

3. Once high differential pressure is noted, respond by the method in Work Instruction 3. 
4. During flushing, open strainer isolation valve fully.

5. Shut down the system by the method described in Work Instruction 7 .

\section{Slow Clogging: Unclearable}

1. Begin sluicing tanks by method described in Work Instruction 1 (Appendix B).

2. Over a period of several minutes, partially close the isolation valve for the strainer being operated (VLV370-1 or VLV370-2). The valve should be closed until the PLC alarms.

3. Once high differential pressure is noted, respond by the method in Work Instruction 3.

4. As directed by Work Instruction 3, switch strainers by the method in Work Instruction 5 and flush the strainer off-line by the method in Work Instruction 4.

5. Open the strainer isolation valve fully.

6. Shut down the system by the method described in Work Instruction 7 .

\section{$\underline{\text { Rapid Clogging }}$}

1. Begin sluicing tanks by method described in Work Instruction 1 (Appendix B).

2. Over a period of 30 seconds, partially close the isolation valve for the strainer being operated (VLV370-1 or VLV370-2). The valve should be closed until the PLC alarms.

3. Once high differential pressure is noted, respond by the method in Work Instruction 5 .

4. Open the strainer isolation valve fully.

5. Shut down the system by the method described in Work Instruction 7.

\subsubsection{Emergency Shutdown}

Sluicing system operators will practice responding to abnormal and emergency conditions during the cold test. The practice will include simulated line leaks, pump failures, and strainer plugging.

Minimum Personnel Required: Three system operators

Special Permits: $\quad$ None

Special Equipment: None 
Prerequisites:

Before this test, the system must be set up as described in Chaps. 2 and 3 . The system must have successfully completed the system tests described in Sects. 4.1 through 4.5 and the operators must have completed the training outlined in Sect. 4.6.1.

Testing Instructions:

Simulated Line Leak

1. Begin sluicing tanks by method described in Work Instruction 1 - Sluicing System Startup (Appendix B).

2. Pour 5 gal of water into one of the skid drip pans.

3. Once the PLC alarms, respond by the method described in Work Instruction 9 (Appendix B).

\section{Simulated Pump Failure}

1. Begin sluicing tanks by method described in Work Instruction 1 - Sluicing System Startup (Appendix B).

2. Turn the local switch for one of the operating pumps to the off position.

3. Once the PLC alarms, respond by the method described in Work Instruction 8 (Appendix B).

\subsubsection{Sluicer Movement}

Sluicing system operators and crane operators will practice moving the sluicer and the in-tank camera during the cold test. The training will involve lifting the equipment off tank T1 and placing it back on the tank by the methods described in Work Instructions 10 and 11 (Appendix B).

\subsubsection{Maintenance}

Sluicing system operators and crane operators will practice the most likely maintenance scenarios that are expected. These scenarios include changing strainer baskets, replacing pump belts, and replacing blown rupture disks. These exercises are described in Work Instructions 6, 12, and 13, respectively. To assist applications for radioactive work permits should these actions be required at the OHF site, these activities will be videotaped.

\subsubsection{Operator Testing}

At the completion of testing and training, the competence of sluicing system operators and crane operators will be evaluated with operational drills and a written exam. During the drills, operators will start and operate the system normally and one of the conditions discussed in Sects. 4.6 .2 and 4.6 .3 will be simulated by the lead engineer. Response of the operators will be documented by the lead engineer on a drill evaluation form. 
After successful completion of the drills, each operator will be required to pass a written exam. The exam is broken into five sections. The purpose of each section is to demonstrate an adequate understanding of specific training objectives. The training objectives are as follows:

1. Develop and be able to demonstrate a working understanding of the existing site conditions at the OHF.

2. Develop and be able to demonstrate a working understanding of the purpose and operation of the key system components.

3. Develop and be able to demonstrate a working understanding of the operation of the sluicing system.

4. Develop and be able to demonstrate a working understanding of how to respond to emergencies during system operation.

5. Develop and be able to demonstrate a working understanding of safety requirements at the OHF. 


\section{HEALTH AND SAFETY}

TTCTF personnel are providing health and safety oversight during the cold test and will prepare the health and safety documentation, based on information provided by CDM Federal regarding the system operation. A Site Safety and Health Officer will be present to monitor worker safety during all active phases of the cold test. 


\section{WASTE MANAGEMENT}

Disposal of wastes generated during the cold test will be conducted in accordance with the sitespecific problem summary sheet to be prepared by TTCTF personnel. The volume of waste generated is anticipated to be minimal, and will consist largely of excess polyvinyl chloride piping, equipment accessories (e.g., lubricant containers), disposal towels, and personal protective equipment (gloves and disposable coveralls). A list of anticipated types and volumes of any potentially hazardous material that may be used or stored at the TTCTF will be provided to ensure compliance with Robotics hazardous materials storage requirements.

Only potable water will be used during the cold test. Residual potable water and sludge/sediment used during the cold test will not be considered a hazardous waste. TTCTF personnel will manage disposal or disposition of this material after the cold test has been completed. 


\section{REPORTING}

The results of the cold test will be documented in a Technical Memorandum. This memorandum will include a synopsis of activities and the results of all tests conducted. This memorandum will be prepared and distributed to project personnel. 
Appendix A

\section{CHECKLISTS}




\begin{tabular}{|l|l|}
\hline $\begin{array}{l}\text { Checklist 4.1a: } \begin{array}{c}\text { System Leak Test } \\
\text { Low Pressure Transfer Pipe Test }\end{array} \\
\begin{array}{l}\text { OHF Tank Contents Removal Project Cold Test } \\
\text { Oak Ridge National Laboratory, Oak Ridge, Tennessee }\end{array}\end{array}$ & $\begin{array}{l}\text { Page 1 of 1 } \\
\text { Date: Nov. 21, 1997 }\end{array}$ \\
\hline Prepared by: CDM Federal Programs Corporation & \\
\hline
\end{tabular}

\section{Initials Criteria}

$$
\text { Test pressure was __ psi. }
$$

No leaks were observed in the low pressure transfer line.

No leaks were observed in the camera rinse lines.

No leaks were observed in the piping on the transfer pump skid.

No leaks were observed in the process water piping.

Comments:

Signature

Date

System Operator

System Operator

Project Engineer 


\begin{tabular}{|l|l|}
\hline $\begin{array}{c}\text { Checklist 4.1b: } \begin{array}{c}\text { System Leak Test } \\
\text { High Pressure Pump Intake Line Test }\end{array} \\
\begin{array}{l}\text { OHF Tank Contents Removal Project Cold Test } \\
\text { Oak Ridge National Laboratory, Oak Ridge, Tennessee }\end{array}\end{array}$ & Page 1 of 1 \\
\hline Prepared by: CDM Federal Programs Corporation & \\
\hline
\end{tabular}

Initials Criteria

Test pressure was __
No leaks were observed in the low pressure feed line.
No leaks were observed in the low pressure feed recycle line.
No leaks were observed in the piping on the transfer pump skid.

Comments:

Signature

Date

System Operator

System Operator

Project Engineer 


\begin{tabular}{|l|l|}
\hline $\begin{array}{c}\text { Checklist 4.1c: } \begin{array}{c}\text { System Leak Test } \\
\text { High Pressure Pump Discharge Line Test }\end{array} \\
\text { Devision: 1 } \\
\text { Date: Nov. 21, 1997 }\end{array}$ \\
\hline $\begin{array}{l}\text { OHF Tank Contents Removal Project Cold Test } \\
\text { Oak Ridge National Laboratory, Oak Ridge, Tennessee }\end{array}$ & Page 1 of 1 \\
\hline Prepared by: CDM Federal Programs Corporation & \\
\hline
\end{tabular}

Initials Criteria
Test pressure was psi.

No leaks were observed in the high pressure recycle line.

No leaks were observed in the MVST transfer line.

No leaks were observed in the strainer drain line.

No leaks were observed in the sluicer pump feed line.

No leaks were observed in the sluicer pressure relief line.

No leaks were observed in the piping on the transfer pump skid.

No leaks were observed in the piping on the sluicer pump skid.

Comments:

Signature

Date

System Operator

System Operator

Project Engineer 


\begin{tabular}{|l|l|}
\hline $\begin{array}{c}\text { Checklist 4.2.1: } \begin{array}{c}\text { Instrumentation and Controls Test } \\
\text { Field Inst. and Equip. Tagging Verification }\end{array} \\
\begin{array}{l}\text { OHF Tank Contents Removal Project Cold Test } \\
\text { Oak Ridge National Laboratory, Oak Ridge, Tennessee }\end{array}\end{array}$ & $\begin{array}{l}\text { Revision: 1 } \\
\text { Date: Nov. 21, 1997 }\end{array}$ \\
\hline Prepared by: CDM Federal Programs Corporation & Page 1 of 1 \\
\hline
\end{tabular}

Initials Criteria

Instruments and equipment tags are installed and labeled correctly.

Comments:

Signature

Date

System Operator

I\&C Engineer

Project Engineer 


\begin{tabular}{|l|l|}
\hline $\begin{array}{c}\text { Checklist 4.2.2: } \\
\text { Instrumentation and Controls Test } \\
\text { PLC, Workstation and Panel Audit }\end{array}$ & $\begin{array}{l}\text { Revision: 1 } \\
\text { Date: Nov. 21, 1997 }\end{array}$ \\
\hline $\begin{array}{l}\text { OHF Tank Contents Removal Project Cold Test } \\
\text { Oak Ridge National Laboratory, Oak Ridge, Tennessee }\end{array}$ & Page 1 of 1 \\
\hline Prepared by: CDM Federal Programs Corporation & \\
\hline
\end{tabular}

\section{Initials Criteria}

Workstation equipment, PLC equipment and cables are installed and labeled correctly.

Panel layout is correct and workmanship is acceptable.

Comments:

Signature

Date

System Operator

I\&C Engineer

Project Engineer 
Cold Test

Revision: 1

Process //O Verification Test

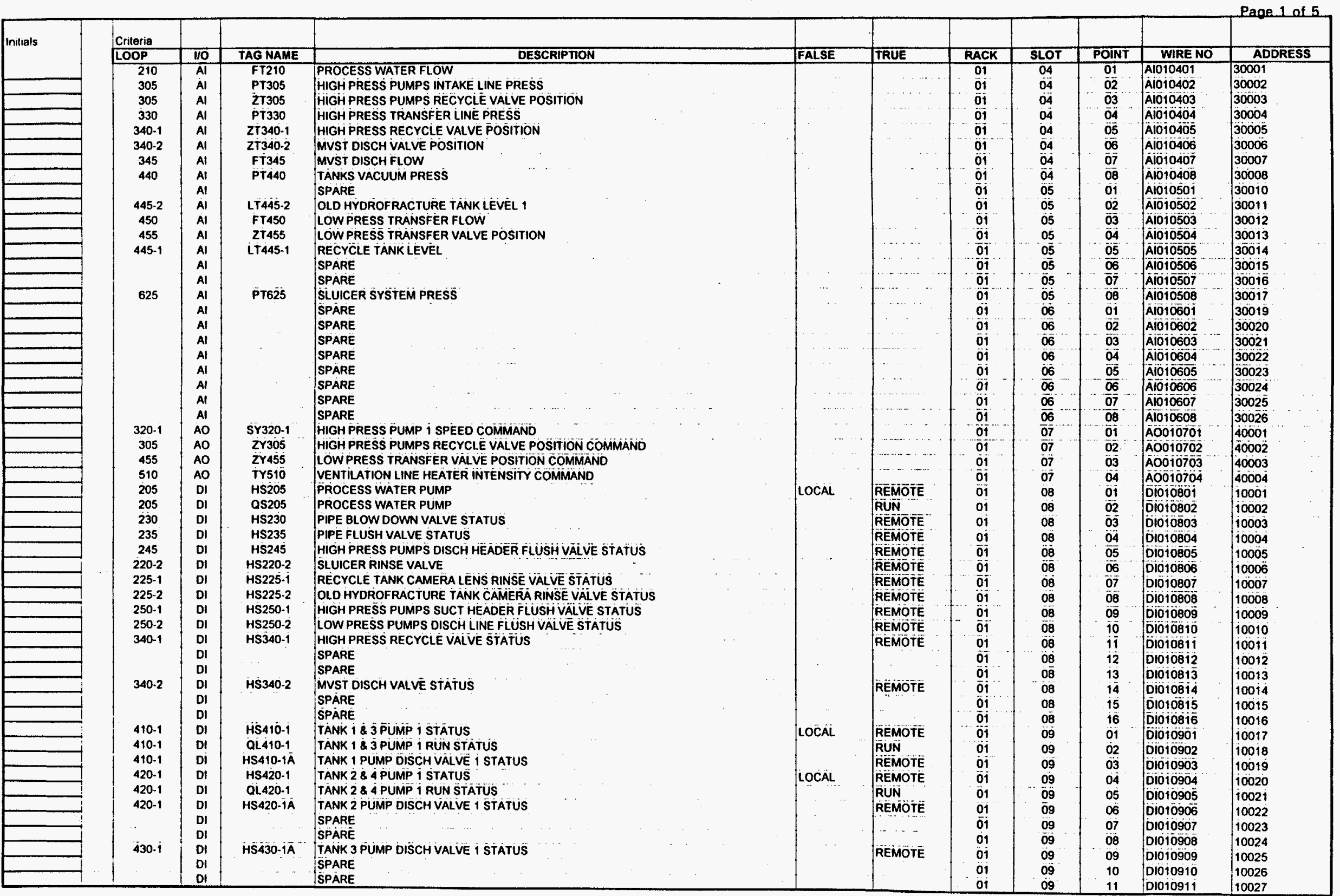


Process 1/O Verification Test

\begin{tabular}{|c|c|c|c|c|c|c|c|c|c|c|c|}
\hline \multirow[t]{2}{*}{ Initials } & $\mid \frac{\text { Criteria }}{\text { LOOOP }}$ & T10 & TAG NAME & DESCRIPTION & & TRUE & RACK & G0T & & & \\
\hline & 440.1 & DI & $\frac{\text { TAS NAME }}{\text { HS440-1A }}$ & TANK 4 PUMP DISCH VALVE TSTATUS & FALSE & REMOTE & KaCK & & POINT & WIRE NO & ADORESS \\
\hline & 320.1 & DI & HS320-1 & HIGH PRESS PUMP q STATUS & LOCAL & REMOTE & $\ddot{0}$ & $\begin{array}{l}09 \\
09\end{array}$ & $\begin{array}{l}12 \\
13\end{array}$ & $\mid \begin{array}{l}01010912 \\
01010913\end{array}$ & $\mid \begin{array}{l}50028 \\
10029\end{array}$ \\
\hline & $320-1$ & DI & PA320-1 & HIGH PRESS PUMP 1 PRESS SHUTDOWN ALARM & NORMAL & Sown & 01 & 09 & 14 & D1010914 & 10030 \\
\hline & $320-1$ & DI & QA320-1 & HIGH PRESS PUMP I VFO DRIVE ALARM & NORMALL & FAil & oi & 09 & 15 & Dio10915 & 10031 \\
\hline & 320-1 & DI & QL320-1 & HIGH PRESS PUMP I RUN STATUS & & RUN & 01 & 09 & 16 & D1010916 & 10032 \\
\hline & $410-2$ & DI & HS4 $40-2$ & TANK 1 \& 3 PUMP 2 STATUS & LOCAL & REMOTE & 01 & 10 & 01 & 01011001 & 10033 \\
\hline & $410-2$ & DI & QL410-2 & TANK 183 PUMP 2 RUN STATUS & & RUUN & 01 & 10 & $0 \overline{2}$ & Dio1 1002 & 10034 \\
\hline & $410-2$ & DI & HS410-2A & TANK 1 PUMP DISCH VALVE 2 STATUS & & R̈EMOTE & 01 & io & 03 & Dio11003 & 10035 \\
\hline & $420-2$ & DI & HS420.2 & TANK $2 \& 4$ PUMP 2 STATUS & LOCAL & REMOTE & 01 & 10 & 04 & Dioi1004 & 10036 \\
\hline & $420-2$ & DI & QL 420.2 & TANK $2 \& 4$ PUMP 2 RUN STATUS & & RUN & 01 & 10 & 05 & Dio11005 & 10037 \\
\hline & $420-2$ & Di & HS420-2A & TANK 2 PUMP DISCH VALVE 2 STATUS & & REMOTE & 01 & 10 & 0 & Döioitioō & 10038 \\
\hline & & DI & & SPARE & & & 01 & 10 & 07 & Dioi1007 & 10039 \\
\hline & & Di & & SPARE & & & oi & 10 & $0 \bar{B}$ & pioinoos & 10040 \\
\hline & 430.2 & DI & HS430-2A & TANK 3 PUMP DISCH VALVE 2 ȘTÁTUS & & REMOTE & 01 & 10 & 09 & Dio11009 & 10041 \\
\hline & & DI & & SPARE & & & 01 & 10 & 10 & 0101010 & 10042 \\
\hline & & DI & & SPARE & & $\cdots$ & 01 & 10 & 11 & Dioi1011 & 100043 \\
\hline & $440-2$ & DI & HS440-2A & TANK 4 PUMP DISCH VALVE 2 ȘTATUS & & REMOATËE & ö1 & 10 & 12 & ODio11012 & 10044 \\
\hline & $320-2$ & DI & HS320-2 & HIGH PRESS PUMP 2 STATUS & LOCAI & REMOTE & 01 & 10 & $1 \overline{3}$ & Diöitiois & 10045 \\
\hline & $320-2$ & DI & PA320-2 & HIGH PRESS PUMP 2 PRESS SHUTOOWN ALARM & NORMAL & SOWWN & $0 \underline{0} \dot{i}$ & 90 & $1 \overline{4}$ & Diatiöid & 10046 \\
\hline & 320.2 & ol & OA320-2 & HIGH PRESS PUMP 2 VFD DRIVE ALARM & NORMAL & FÄIL & 01 & 10 & 15 & Dioito15 & 10047 \\
\hline & $320-2$ & DI & $0 L 320-2$ & HIGH PRESS PUMP 2 RUN STATUS & & RUUN & 01 & 90 & 16 & Dioi10̄î & 10048 \\
\hline & $350-1$ & DI & HS350-1 & STRAINER VALVE 1 STATUS & & REMMOTÉE & ố & $\mathbf{i 1}$ & 01 & Dioị101 & 10049 \\
\hline & $360-1$ & DI & HS360-1 & STRAINER DRAIN VALVE 1 STATUS & & REMOTE & 01 & 11 & 02 & Dio11102 & 10050 \\
\hline & 300 & DI & HS300 & RECYCLE TANK DISCH VALVE STATUS & & REMMOIOTE & 01 & ii & 03 & D̈́loitios & $1005 i$ \\
\hline & 305 & DI & HS 305 & HIGH PRESS PUMPS RECYCLE VALVE STATUS & & REMOTE & $0 i$ & $1 i$ & 04 & 0101104 & 10052 \\
\hline & 305 & DI & PSH305 & HIGH PRESS PUMPS INTAKE LINE PRESS ALARM & NORMAL & HIGH & $0 \ddot{1}$ & i1 & 05 & Dioi1ios & 10053 \\
\hline & & DI & & SPARE & & & 01 & ii & $\underline{0} \underline{6}$ & Dioilio6 & 10054 \\
\hline & & DI & & SPARE & & & 01 & i1 & $\overline{o j}$ & Dio11107 & 10055 \\
\hline & 330 & DI & PSH330 & HIGH PRESSS TRANSFER LINE PRESS ALARM & INOR̈MAL & HIGH & 01 & 11 & 08 & Dio11108 & 10056 \\
\hline & 400 & DI & HS400 & RECYCLE TANK MIXER STATUS & LOCAL & REMOTE & 01 & 11 & $0 \overline{9}$ & Diói1iog & 10057 \\
\hline & 400 & OI & QL400 & RECYCLE TANK MIXER RUUN STATUS & & RUN & 01 & i1 & 10 & Dion1110 & 10058 \\
\hline & 445 & DI & PAL 445 & BUBBLER SYSTEM AIR̈ PRËSS ALARM & NOORMAL & Low & 01 & 11 & 11 & Dioi1119 & 10059 \\
\hline & 455 & DI & HS455 & LOW PRESS TRANSFER VALVE STATUS. & & REMOTE & 01 & $i i$ & 12 & Dioi11!2 & 10060 \\
\hline & & DI & & SPARE & & & 01 & 11 & 13 & 01011113 & i0061 \\
\hline & & DI & & SPARE & & & 01 & 11 & $i \overline{4}$ & Diolitia & 10062 \\
\hline & 495 & DI & HS495 & RECYCLE TANK PUMP STATUS & LOC̄ÄL & REMOTE & $0 \underline{1}$ & $1 \overline{1}$ & 15 & Dioi1115 & 10063 \\
\hline & 495 & DI & QL495 & RECYCLE TANK PUMP RUN STATUS & & RUUN & $\overline{0 i}$ & 11 & 16 & Dio1iiti & 10064 \\
\hline & 350.2 & DI & HS350-2 & STRAINER VALVE 2 STATUS & & REMOÖTË & 01. & 12 & 01 & 01011201 & 10065 \\
\hline & $360-2$ & DI & HS360.2 & STRAINER DRAIN VALVE 2 STATUS & & REMOTE & 01 & 12 & 02 & 01011202 & 10066 \\
\hline & 510 & OI & HS510 & VENTILATION LINE HEEATER STATUS & & REMOTE & 01 & 12 & 03 & 01011203 & 10067 \\
\hline & 545 & DI & HSSAS & VENTILATION FAN STATUUS & LOC̈ÄL & REMOTË. & 01 & 12 & 04 & 01011204 & 10068 \\
\hline & 545 & DI & QL545 & VEENTILATION FAN RUN STATUUS & & RUN & $0 \bar{i}$ & 12 & 05 & D1011205 & 10069 \\
\hline & 600 & DI & YLG00 & SIIUICER CONTROL CONSOLE POWER & OFF & ON & 01 & $\sqrt{2}$ & 06 & 01011206 & 10070 \\
\hline & 605 & DI & YL605 & SLUICER CONTROL CONSOLE SYSTEM ON & OFF & lon & 01 & 12 & 07 & Dio11207 & 10071 \\
\hline & 610 & DI & XAGio & SLUUICER CONTROL CONSOLE E-STOP ALARM & NORMAL & EșTöö & 01 & 12 & 00 & Di011208 & 10072 \\
\hline & 615 & DI & YLGi5 & S̈LUUICER SYSTEM HYDRAULIC POWER ON & OFF & ON & $\ddot{0}$ & 12 & 09 & D1011209 & 10073 \\
\hline & 660 & D! & HS660 & SLUCCIER PUMP INTAKE VALVE STATUUS & & REMOTE & 01 & 12 & 10 & Dioi1210 & 10074 \\
\hline & 665 & Di & HS665 & S̈LÜICER PUMP STATUS & LOCÁL & REMOTE & 01 & 12 & 11 & D1011211 & 10075 \\
\hline & 665 & DI & PA665 & SLUUICER PUMP PRESS SHUTOZOWN & NORMAL & SOWN & 01 & 12 & 12 & Di011212 & 10076 \\
\hline & 665 & DI & $0 A 665$ & SLUICER PUMMP VF̃O DRIVE FAAIL & NORMAL & FAii & $0 \underline{1}$ & 12 & 13 & Dio11213 & \\
\hline & 665 & DI & QL665 & SL UUCER PUMMP RÜN STATIUSS & & RUN & 01 & 12 & 14 & bio112ia & 10078 \\
\hline & 670 & Di & HS6̈O & SLUUUCER PUMP PRESSS RELEASE VALVE STATUUS & & REMMOTEZ & 01 & 12 & 15 & Dio11215 & 10079 \\
\hline & 675 & DI & HS675 & ŠLiUICER P̈UMP DISCH VALVE STATUUS & & REMOTE & $01^{-}$ & 12 & 16 & Dioi1216 & 10080 \\
\hline & $665 \mathrm{~A}$ & D! & HS̈665A & SLLUICER PUMP BYPASS VALVE STATUS̄ & & REMOTE & oi & 13 & 01 & Di011301 & 10081 \\
\hline & $715-\overline{1}$ & $\mathrm{Di}$ & LAH'TíT-1 & PUMMP SKIÖ ORIP PAN FLOOO ALÄRM & NOERMAL & FLOOD & 01 & 13 & 02 & 01011302 & 10082 \\
\hline
\end{tabular}


Cold Test

Revision: 1

Process 1/O Verification Test

\begin{tabular}{|c|c|c|c|c|c|c|c|c|c|c|c|}
\hline \multirow[t]{3}{*}{ Intials } & Criteria & & & & & & & & & & \\
\hline & LOOP & 110 & TAG NAME & DESCRIPTION & FALSE & TRUE & RÁCK & SLOT & POINT & WIRE NO & ADDRESS \\
\hline & $715-2$ & Dा & LAH715-2 & SLUICER SKID DRIP PAN FLOOD ALARM & NORMAL & FLOOD & 01 & 13 & 03 & 01011303 & 10083 \\
\hline & $715-3$ & DI & LAH715-3 & VENTILATION SKID ORIP PAN FLOOD ALARM & NORMAL & FLOOD & 01 & 13 & 04 & Dioi1304 & 10084 \\
\hline & 715-4 & סI & LAH715-4 & RECYCLE TANK RISER FLOOD ALARM & NORMAL & FLOOD & 01 & 13 & 05 & Diö11305 & 10085 \\
\hline & $715-5$ & DI & LAH715-5 & OLD HYORO TANK 1 RISER FLODD ALARM & NORMAL & FLOOD & 01 & 13 & 06 & Dio11306 & 10086 \\
\hline & $715-6$ & DI & LAH715-6 & OLD HYORO TANK 2 RISER FLOOD ALARM & NORMAL & FioOod & 01 & 13 & 07 & Dio11307 & 10087 \\
\hline & 715.7 & DI & LAH7 $+5-7$ & OLD HYORO TANK 3 RISER FLOOD ALARM & NORMAL & FLOOD & 01 & 13 & 08 & Dioi 1308 & 10088 \\
\hline & $715-8$ & DI & LAH715.8 & OLD HYORO TANK 4 RISER FLOOD ALARM & NORMAL & FLOOD & 01 & 13 & 09 & Díi 1309 & 10089 \\
\hline & & DI & & SPARE & & & 01 & $1 \overline{3}$ & io & D̄iōiisian & 10090 \\
\hline & & $\mathrm{DI}$ & & SPARE & & & 01 & 13 & ii & Dioi1311 & 10091 \\
\hline & & DI & & SPARE & & & 01 & 13 & 12 & Dio11312 & 10092 \\
\hline & & DI & & SPARE & & & 01 & 13 & 13 & D1O1 1313 & 90093 \\
\hline & & DI & & SPARE & & & 01 & 13 & 14 & Dio1 1314 & 10094 \\
\hline & & DI & & SPARE & & & 01 & 13 & 15 & 01011315 & 10095 \\
\hline & & DI & & SPARE & & & 01 & 13 & 16 & 01011316 & 10096 \\
\hline & & Al & & SPARE & & & 02 & 03 & 01 & A1020301 & 30028 \\
\hline & $445-3$ & A) & LT445-3 & OLD HYDROFRACTURE TANK LEVEL 2 & & & $0 \overline{2}$ & 03 & 02 & A1020302 & 30029 \\
\hline & 630 & A) & PT630 & SLUICER ARM CONTROL PRESS & & & 02 & 03 & 03 & Ä1020303 & 30030 \\
\hline & 635 & Al & PT635 & SLUICER EXTENSION PRESS & & & 02 & 03 & 04 & AlO20304 & 30031 \\
\hline & 640 & Al & PTG40 & SLUICER MAST PRESS & & & 02 & 03 & $\overline{0} \overline{5}$ & A1020305 & 30032 \\
\hline & 645 & Al & ZT645 & SLUICER ARM ANGLE & & & 02 & 03 & 06 & A1020306 & 30033 \\
\hline & 650 & Al & $2 T 650$ & SLUICER ARM EXTENSION & & & 02 & 03 & 07 & A1O20307 & 30034 \\
\hline & 655 & Al & 27655 & SLUICER MAST ANGLE & & & $0 \overline{2}$ & 03 & $0 \theta$ & Ä102030日 & 30035 \\
\hline & 663 & Al & PT663 & SLUICER PUMP INTAKE PRESSURE & & & 02 & 04 & 01 & Aio 020401 & 30037 \\
\hline & 665 & Al & ST665 & SLUICER PUMP SPEED & & & 02 & 04 & 02 & AíO20402 & 30038 \\
\hline & 668 & Al & PT668 & SLUICER PUMP DISCH PRESS & & & 02 & 04 & 03 & $A \overline{1} 2020403$ & 30039 \\
\hline & 505 & Al & $\pi 505$ & |VENTILATION LINE UPSTREAM TEMP & & & $0 \overline{2}$ & 04 & 04 & A1020404 & 30040 \\
\hline & 515 & Al & $\pi 515$ & VENTILATION LINE DOWNSTREAM HEATER & & & 02 & 04 & 05 & A1020405 & $3004 i$ \\
\hline & 520 & AI. & PDT520 & VENTILATION LINE $90 \%$ FILTER DIFF PRESS & & & 02 & 04 & $\ddot{06}$ & Ä1020406 & 30042 \\
\hline & 525 & Al & PDT525 & VENTILATION LINE HEPA FILTER I DIFF PRESS & & & $0 \overline{2}$ & 04 & 07 & A1020407 & 30043 \\
\hline & 530 & Al & PDI530 & VENTILATION LINE HEPA FIL TER 2 DIFF PRESS & & & 02 & 04 & $0 \overline{8}$ & A1020408 & 30044 \\
\hline & 500. & Al & POr500 & DEMISTER DIFF PRESS & & & 02 & 05 & 01 & Aio20501 & 30046 \\
\hline & 535 & Ai & AT535 & VENTILATION LINE HUMIDITY & & & 02 & 05 & 02 & AiOO20502 & 30047 \\
\hline & 540 & Al & FT540 & VENTILATION LINE FLOW & & & 02 & 05 & 03 & Á1020503 & 30048 \\
\hline & 700 & Al & RT700 & RADIATION MONITOR - RECYCLE TANK & & & $\underline{02}$ & 05 & $0 \dot{4}$ & Á1020504 & 30049 \\
\hline & 705 & Al & RT705 & RADIATION MONITOR - HYOROFRACTURE TANK & & & 02 & 05 & 05 & A1020505 & 30050 \\
\hline & 710 & Al & RTi10 & RADIATION MONITOR - PUMMPING SKID & & & 02 & 05 & 06 & Á1020506 & 30051 \\
\hline & & A! & & SPARE & & & 02 & 05 & 07 & A1020507 & 30052 \\
\hline & & Ai & & |SPARE & & & 02 & 05 & 08 & Aí020500 & 30053 \\
\hline & $320-2$ & AO & sY320-2 & ¡HIGH PRESSS PUMP 2 SPEED COMMAND & & & 02 & $\overline{06}$ & 01 & $A 0020601$ & 40005 \\
\hline & $340-1$ & AO & $Z Y 340 . \dot{1}$ & HIGH PRESS RECYCLE VALVE POSITION COMMMAND & & & 02 & 06 & $0 \dot{2}$ & A0020602 & 40006 \\
\hline & $340-2$ & AO & $2 \times 340-2$ & MVST DISCH VALVE POSITION COMMANÓ & & & 02 & 06 & $\tilde{0} \overline{3}$ & AO020603 & 40007 \\
\hline & 665 & AO & SY665 & SLUICER PUMP SPEEO COMMMAND & & & 02 & 06 & 04 & AO020604 & 40008 \\
\hline & & AO & & |SPARE & & & $0 \overline{2}$ & 07 & 01 & $A 0020701$ & 40009 \\
\hline & & AO & & JSPARE & & & 02. & 07 & 02 & AO020702 & 40010 \\
\hline & & AO & & jSPARE & & & 02 & 07 & 03 & $A 0020703$ & 40011 \\
\hline & & AO & & SPARE & & & 02 & 07 & 04 & AO020704 & 40012 \\
\hline & 205 & Do & P205 & PROCESS WATER PUMPP & STTOP & START & 02 & 08 & 01 & DO020801 & 00001 \\
\hline & 230 & DO & V230 & PIPE BLOW DOWN VALVE CÖMMAND & CLOSE & OPEN & $\mathbf{0 2}$ & $0 \theta$ & 02 & D0020802 & 00002 \\
\hline & 235 & Do & v235 & PIPE FLUSH VALVE COMMAND & CLOSĒE & OPEN & 02 & og & 03 & 00020803 & 00003 \\
\hline & 245 & Do & $v_{2} 4 \overline{5}$ & HHIGH PRESS PUMPS DISCH HEADER FLUSH VALVE COMMAND & CLOSE & OPEN & 02 & 08 & 04 & 00020804 & 00004 \\
\hline & $220-2$ & DO & v220.2 & SLUUCER R̈INSE VALVE & CLOSE & OPEN & 02 & 00 & 05 & D0020805 & 00005 \\
\hline & $225-1$ & DO & V225-1 & RECYCLE TANK CAMERA LENS RINSE VALVE COMMIANO & CLLOSE & ÖPEN & 02 & 08 & 06 & 00020806 & 00006 \\
\hline & 225.2 & DO & $\sqrt{2} 25-\overline{2}$ & OLOO HYDRO TANK CAMERA RINSE VALVË COMMMÄNO & CLOSE & OPEN & 02 & 00 & 07 & D0020807 & 00007 \\
\hline & $250-1$ & DO & $\mathrm{V} 250-\mathrm{i}$ & HIGH PRESS PUMPS SUCT HEADER FLUSH VALVE COMMAND & CLOSE & OPEN & 02 & 08 & 08 & 00020808 & 00008 \\
\hline & $250-2$ & Do & $\sqrt{2} 250-2$ & LOW PRESS PUMPS DISCH LINE FLUSH VAL VE COMMANO & CLOSE & OPEN & 02 & 08 & 09 & D0020809 & 00009 \\
\hline
\end{tabular}




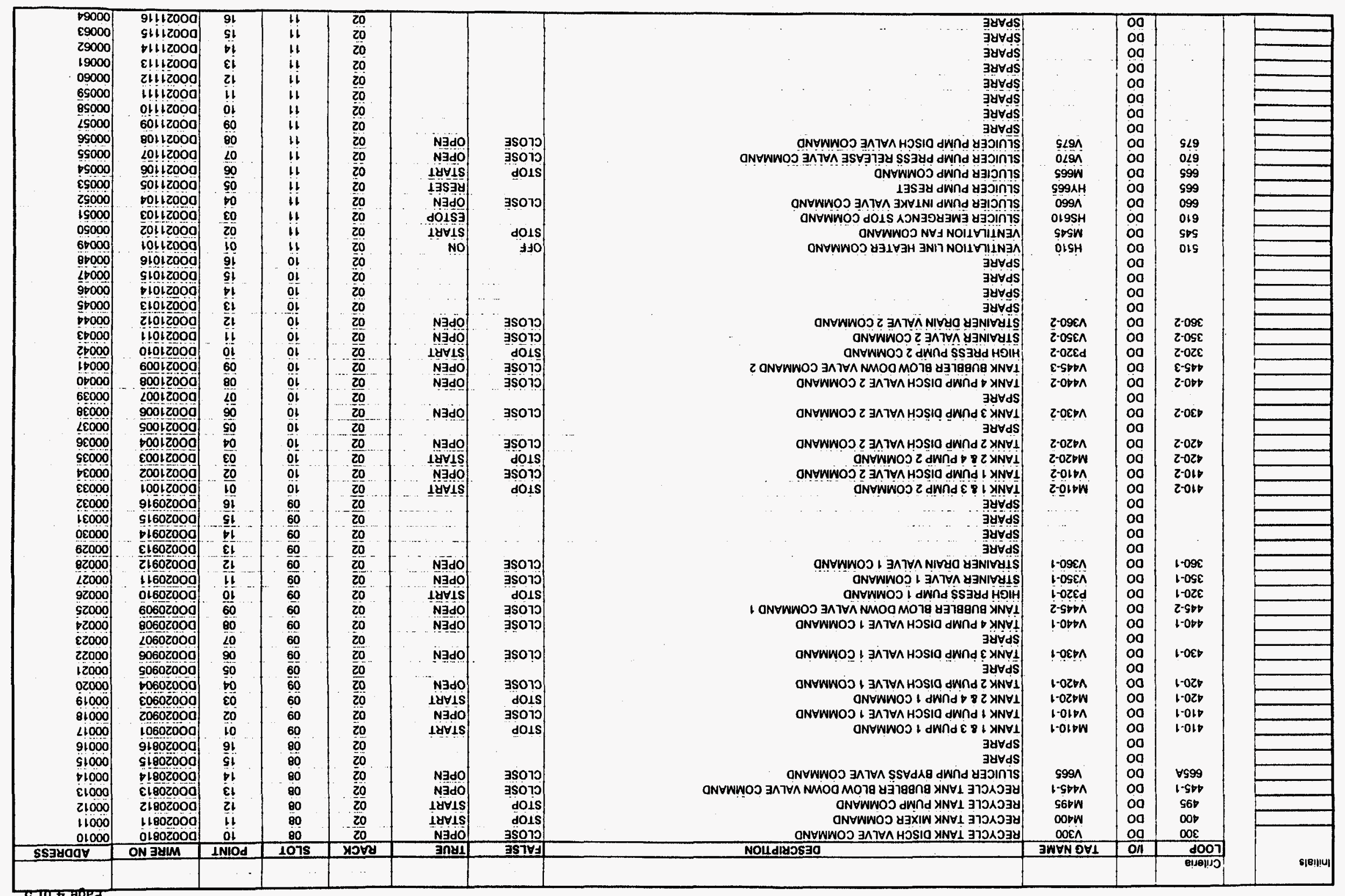


Process 1/O Verification Test

\begin{tabular}{|c|c|c|c|c|c|c|c|c|c|c|c|}
\hline Initials & \begin{tabular}{|l} 
Criteria \\
LOOP \\
\end{tabular} & $1 / 0$ & TAG NAME & DESCRIPTION & FALSE & TRUE & RACK & SLOT & POINT & WIRE NO & ADDRESS \\
\hline & & DO & & SPARE & & & 02 & 12 & 01 & 00021201 & 00065 \\
\hline & & DO & & SPARE & & & 02 & 12 & 02 & 00021202 & 00066 \\
\hline & & Do & & SPARE & & & 02 & 12 & 03 & 00021203 & 00067 \\
\hline & & DO & & SPARE & & & 02 & 12 & 04 & 00021204 & 00068 \\
\hline & & Do & & SPARE & & & 02 & 12 & 05 & D0021205 & 00069 \\
\hline & & DO & & SPARE & & & 02 & 12 & 06 & 00021206 & 00070 \\
\hline & & DO & & SPARE & & & 02 & 12 & 07 & 00021207 & 00071 \\
\hline & & DO & & SPARE & & & 02 & 12 & 08 & 00021208 & 00072 \\
\hline & & 00 & & SPARE & & & 02 & 12 & 09 & 00021209 & 00073 \\
\hline & & DO & & SPARE & & & 02 & 12 & 10 & 00021210 & 00074 \\
\hline & & DO & & SPARE & & & 02 & 12 & 11 & 00021211 & 00075 \\
\hline & & DO & & 'SPARE & & & 02 & 12 & 12 & 00021212 & 00076 \\
\hline & & DO & & SPARE & & & 02 & 12 & 13 & 00021213 & 00077 \\
\hline & & DO & & SPARE & & & 02 & 12 & 14 & 00021214 & 100078 \\
\hline & i & DO & & SPARE & & & 02 & 12 & 15 & 00021215 & 00079 \\
\hline & & DO & & SPARE & & & 02 & 12 & 16 & 00021216 & 00080 \\
\hline
\end{tabular}




\begin{tabular}{|l|l|}
\hline $\begin{array}{c}\text { Checklist 4.2.4: } \\
\text { Instrumentation and Controls Test } \\
\text { PLC, Workstation and Panel Failure }\end{array}$ & $\begin{array}{l}\text { Revision: 1 } \\
\text { Date: Nov. 21, 1997 }\end{array}$ \\
\hline $\begin{array}{l}\text { OHF Tank Contents Removal Project Cold Test } \\
\text { Oak Ridge National Laboratory, Oak Ridge, Tennessee }\end{array}$ & Page 1 of 1 \\
\hline Prepared by: CDM Federal Programs Corporation & \\
\hline
\end{tabular}

Initials Criteria

UPS functions properly.

Workstation functions properly on power loss and recovery.

PLC functions properly on power loss and recovery.

PLC Remote I/O functions properly on power loss and recovery.

Workstation and PLC communications function properly on loss of communication and restoration of communications.

Comments:

Signature

Date

System Operator

I\&C Engineer

Project Engineer 
Checklist 4.2.5.1:

Instrumentation and Controls Test

Revision: 1

Loop 205 Process Water Pump and

Loop 210 Process Water Flow Test

OHF Tank Contents Removal Project Cold Test

Date: Nov. 21, 1997

Oak Ridge National Laboratory, Oak Ridge, Tennessee

Page 1 of 2

Prepared by: CDM Federal Programs Corporation

Initials Criteria

A. Review the associated displays for layout and completeness.

Display layout is correct and complete.

B. Point and display verification

Verify pump field switch status indicates Local at display.

Verify pump status indicates Computer Manual at display.

Verify pump status indicates Off at display.

Change pump field switch to the Remote position and verify pump status changes to Remote at display.

Using input simulation equipment, simulate a flow signal. Verify that the engineering units conversion is performed correctly. Verify trend is functioning correctly.

Verify flow totalization is working. Select flow totalization Reset at display and confirm flow total is set to 0 .

C. Manual Control

With pump field switch in the Local position, Select pump Start at display and verify that pump does not Run.

Change pump field switch to the Remote position. Select pump Start at display and verify pump status changes to Run at display.

Select pump Stop at display and verify pump status changes to Off at display. 
Checklist 4.2.5.1:

Instrumentation and Controls Test

Revision: 1

Loop 205 Process Water Pump and

Loop 210 Process Water Flow Test

OHF Tank Contents Removal Project Cold Test

Page 2 of 2

Date: Nov. 21, 1997

Oak Ridge National Laboratory, Oak Ridge, Tennessee

Prepared by: CDM Federal Programs Corporation

D. Equipment Failure

Disable pump from running. Select pump Start at display and verify pump status indicates Off at display. After 10 seconds, verify that an equipment failure alarm is generated.

Select pump Start and verify PLC start output does not energize.

Select pump fail Reset at display. Enable pump to run and select pump Start at display and verify pump status changes to Run at display. Select pump Stop at display.

E. Interlocks

Select pump Start at display. With pump confirmed running, simulate a no flow condition. After 5 seconds, verify that a No Flow Alarm is generated and the pump is shut off.

Comments:

Signature

Date

System Operator

I\&C Engineer

Project Engineer 
Checklist 4.2.5.2:

Instrumentation and Controls Test

Revision: 0

Loop 220-2 Sluicer Rinse Valve

OHF Tank Contents Removal Project Cold Test

Date: Aug. 29, 1997

Oak Ridge National Laboratory, Oak Ridge, Tennessee

Prepared by: CDM Federal Programs Corporation

Initials Criteria

A. Review the associated displays for layout and completeness.

Display layout is correct and complete.

B. Point and display verification.

Verify valve field switch status indicates Local at display.

Select Computer Auto at display and verify status indicates Computer Auto at display.

Select Computer Manual at display and verify status indicates Computer Manual at display.

Change valve field switch to the Remote position and verify valve status changes to Remote at display.

C. Manual Control

With valve field switch in the Close position, Select valve Open at display and verify that valve does not Open.

With valve field switch in the Open position, Select valve Close at display and verify that valve does not Close.

Change valve field switch to the Remote position.

Select valve Open at display and verify that valve opens.

Select valve Close at display and verify that valve closes. 
Checklist 4.2.5.2:

Revision: 0

Instrumentation and Controls Test

Date: Aug. 29, 1997

Loop 220-2 Sluicer Rinse Valve

OHF Tank Contents Removal Project Cold Test

Page 2 of 2

Oak Ridge National Laboratory, Oak Ridge, Tennessee

Prepared by: CDM Federal Programs Corporation

Comments:

Signature

Date

System Operator

I\&C Engineer

Project Engineer 
Checklist 4.2.5.3:

Instrumentation and Controls Test

Revision: 0

Date: Aug. 29, 1997

Loop 225-1 Recycle Tank Camera Lens Rinse Valve

OHF Tank Contents Removal Project Cold Test

Page 1 of 2

Oak Ridge National Laboratory, Oak Ridge, Tennessee

Prepared by: CDM Federal Programs Corporation

Initials Criteria

A. Review the associated displays for layout and completeness.

B. Point and display verification.

Verify valve field switch status indicates Local at display.

Select Computer Auto at display and verify status indicates Computer Auto at display.

Select Computer Manual at display and verify status indicates Computer Manual at display.

Change valve field switch to the Remote position and verify valve status changes to Remote at display.

C. Manual Control

With valve field switch in the Close position, Select valve Open at display and verify that valve does not Open.

With valve field switch in the Open position, Select valve Close at display and verify that valve does not Close.

Change valve field switch to the Remote position.

Select valve Open at display and verify that valve opens.

Select valve Close at display and verify that valve closes. 


\begin{tabular}{|l|l|}
\hline $\begin{array}{c}\text { Checklist 4.2.5.3: } \\
\text { Instrumentation and Controls Test } \\
\text { Loop 225-1 Recycle Tank Camera Lens Rinse Valve }\end{array}$ & $\begin{array}{l}\text { Revision: 0 } \\
\text { Date: Aug. 29, 1997 }\end{array}$ \\
\hline $\begin{array}{l}\text { OHF Tank Contents Removal Project Cold Test } \\
\text { Oak Ridge National Laboratory, Oak Ridge, Tennessee }\end{array}$ & Page 2 of 2 \\
\hline Prepared by: CDM Federal Programs Corporation & \\
\hline
\end{tabular}

Comments:

Signature

Date

System Operator

I\&C Engineer

Project Engineer 


\begin{tabular}{|l|l|}
\hline $\begin{array}{c}\text { Checklist 4.2.5.4: } \\
\text { Instrumentation and Controls Test } \\
\text { Loop 225-2 Old Hydrofracture Tank Camera Lens Rinse Valve }\end{array}$ & $\begin{array}{l}\text { Revision: 0 } \\
\text { Date: Aug. 29, 1997 }\end{array}$ \\
\hline $\begin{array}{l}\text { OHF Tank Contents Removal Project Cold Test } \\
\text { Oak Ridge National Laboratory, Oak Ridge, Tennessee }\end{array}$ & Page 1 of 2 \\
\hline Prepared by: CDM Federal Programs Corporation & \\
\hline
\end{tabular}

Initials Criteria

A. Review the associated displays for layout and completeness.

Display layout is correct and complete.

B. Point and display verification.

Verify valve field switch status indicates Local at display.

Select Computer Auto at display and verify status indicates Computer Auto at display.

Select Computer Manual at display and verify status indicates Computer Manual at display.

Change valve field switch to the Remote position and verify valve status changes to Remote at display.

C. Manual Control

With valve field switch in the Close position, Select valve Open at display and verify that valve does not Open.

With valve field switch in the Open position, Select valve Close at display and verify that valve does not Close.

Change valve field switch to the Remote position.

Select valve Open at display and verify that valve opens.

Select valve Close at display and verify that valve closes. 
Checklist 4.2.5.4:

Instrumentation and Controls Test

Loop 225-2 Old Hydrofracture Tank Camera Lens Rinse Valve

OHF Tank Contents Removal Project Cold Test

Oak Ridge National Laboratory, Oak Ridge, Tennessee

Prepared by: CDM Federal Programs Corporation
Revision: 0

Date: Aug. 29, 1997

Page 2 of 2

Comments:

Signature

Date

System Operator

I\&C Engineer

Project Engineer 


\begin{tabular}{|l|l|}
\hline $\begin{array}{c}\text { Checklist 4.2.5.5: } \\
\text { Instrumentation and Controls Test } \\
\text { Loop 230 Pipe Blow Down Valve }\end{array}$ & $\begin{array}{l}\text { Revision: 0 } \\
\text { Date: Aug. 29, 1997 }\end{array}$ \\
\hline $\begin{array}{l}\text { OHF Tank Contents Removal Project Cold Test } \\
\text { Oak Ridge National Laboratory, Oak Ridge, Tennessee }\end{array}$ & Page 1 of 2 \\
\hline Prepared by: CDM Federal Programs Corporation & \\
\hline
\end{tabular}

Initials Criteria

A. Review the associated displays for layout and completeness.

Display layout is correct and complete.

B. Point and display verification.

_ Verify valve field switch status indicates Local at display.

Select Computer Auto at display and verify status indicates Computer Auto at display.

Select Computer Manual at display and verify status indicates Computer Manual at display.

Change valve field switch to the Remote position and verify valve status changes to Remote at display.

C. Manual Control

With valve field switch in the Close position, Select valve Open at display and verify that valve does not Open.

With valve field switch in the Open position, Select valve Close at display and verify that valve does not Close.

Change valve field switch to the Remote position.

Select valve Open at display and verify that valve opens.

Select valve Close at display and verify that valve closes. 


\begin{tabular}{|l|l|}
\hline $\begin{array}{c}\text { Checklist 4.2.5.5: } \\
\text { Instrumentation and Controls Test } \\
\text { Loop 230 Pipe Blow Down Valve }\end{array}$ & $\begin{array}{l}\text { Revision: } 0 \\
\text { Date: Aug. 29, 1997 }\end{array}$ \\
\hline $\begin{array}{l}\text { OHF Tank Contents Removal Project Cold Test } \\
\text { Oak Ridge National Laboratory, Oak Ridge, Tennessee }\end{array}$ & Page 2 of 2 \\
\hline Prepared by: CDM Federal Programs Corporation & \\
\hline
\end{tabular}

Comments:

System Operator

I\&C Engineer

Project Engineer 


\begin{tabular}{|l|l|}
\hline $\begin{array}{c}\text { Checklist 4.2.5.6: } \\
\text { Instrumentation and Controls Test } \\
\text { Loop 235 Pipe Flush Valve }\end{array}$ & $\begin{array}{l}\text { Revision: 0 } \\
\text { Date: Aug. 29, 1997 }\end{array}$ \\
\hline $\begin{array}{l}\text { OHF Tank Contents Removal Project Cold Test } \\
\text { Oak Ridge National Laboratory, Oak Ridge, Tennessee }\end{array}$ & Page 1 of 2 \\
\hline Prepared by: CDM Federal Programs Corporation & \\
\hline
\end{tabular}

Initials Criteria

A. Review the associated displays for layout and completeness.

Display layout is correct and complete.

B. Point and display verification.
Verify valve field switch status indicates Local at display.
Select Computer Auto at display and verify status indicates Computer Auto at display.

Select Computer Manual at display and verify status indicates Computer Manual at display.

Change valve field switch to the Remote position and verify valve status changes to Remote at display.

C. Manual Control

With valve field switch in the Close position, Select valve Open at display and verify that valve does not Open.

With valve field switch in the Open position, Select valve Close at display and verify that valve does not Close.

Change valve field switch to the Remote position.

Select valve Open at display and verify that valve opens.

Select valve Close at display and verify that valve closes. 


\begin{tabular}{|l|l|}
\hline $\begin{array}{c}\text { Checklist 4.2.5.6: } \\
\text { Instrumentation and Controls Test } \\
\text { Loop 235 Pipe Flush Valve }\end{array}$ & $\begin{array}{l}\text { Revision: 0 } \\
\text { Date: Aug. 29, 1997 }\end{array}$ \\
\hline $\begin{array}{l}\text { OHF Tank Contents Removal Project Cold Test } \\
\text { Oak Ridge National Laboratory, Oak Ridge, Tennessee }\end{array}$ & Page 2 of 2 \\
\hline Prepared by: CDM Federal Programs Corporation & \\
\hline
\end{tabular}

Comments:

Signature

Date

System Operator

I\&C Engineer

Project Engineer 


\begin{tabular}{|l|l|}
\hline $\begin{array}{c}\text { Checklist 4.2.5.7: } \begin{array}{c}\text { Instrumentation and Controls Test } \\
\text { Loop 245 High Pressure Pumps Discharge Header Flush Valve }\end{array} \\
\text { OHF Tank Contents Removal Project Cold Test } \\
\text { Oak Ridge National Laboratory, Oak Ridge, Tennessee }\end{array}$ & $\begin{array}{l}\text { Revision: 1 } \\
\text { Date: Nov. 21, 1997 }\end{array}$ \\
\hline Prepared by: CDM Federal Programs Corporation & Page 1 of 2 \\
\hline
\end{tabular}

Initials Criteria

A. Review the associated displays for layout and completeness.

Display layout is correct and complete.

B. Point and display verification.

Verify valve field switch status indicates Local at display.

Select Computer Auto at display and verify status indicates Computer Auto at display.

Select Computer Manual at display and verify status indicates Computer Manual at display.

Change valve field switch to the Remote position and verify valve status changes to Remote at display.

C. Manual Control

With valve field switch in the Close position, Select valve Open at display and verify that valve does not Open.

With valve field switch in the Open position, Select valve Close at display and verify that valve does not Close.

Change valve field switch to the Remote position.

Select valve Open at display and verify that valve opens.

Select valve Close at display and verify that valve closes. 
Checklist 4.2.5.7:

Instrumentation and Controls Test

Loop 245 High Pressure Pumps Discharge Header Flush Valve

OHF Tank Contents Removal Project Cold Test

Oak Ridge National Laboratory, Oak Ridge, Tennessee

Prepared by: CDM Federal Programs Corporation
Revision: 1

Date: Nov. 21, 1997

Page 2 of 2

Comments:

Signature

Date

System Operator

I\&C Engineer

Project Engineer 


\begin{tabular}{|l|l|}
\hline $\begin{array}{c}\text { Checklist 4.2.5.8: } \begin{array}{c}\text { Instrumentation and Controls Test } \\
\text { Loop 250-1 High Pressure Pumps Suction Header Flush Valve }\end{array} \\
\text { OHF Tank Contents Removal Project Cold Test } \\
\text { Oak Ridge National Laboratory, Oak Ridge, Tennessee }\end{array}$ & $\begin{array}{l}\text { Page 1 of 2 } \\
\text { Date: Nov. 21, } 1997\end{array}$ \\
\hline Prepared by: CDM Federal Programs Corporation & \\
\hline
\end{tabular}

Initials Criteria

A. Review the associated displays for layout and completeness.

Display layout is correct and complete.

B. Point and display verification.

Verify valve field switch status indicates Local at display.

Select Computer Auto at display and verify status indicates Computer Auto at display.

Select Computer Manual at display and verify status indicates Computer Manual at display.

Change valve field switch to the Remote position and verify valve status changes to Remote at display.

C. Manual Control

With valve field switch in the Close position, Select valve Open at display and verify that valve does not Open.

With valve field switch in the Open position, Select valve Close at display and verify that valve does not Close.

Change valve field switch to the Remote position.

Select valve Open at display and verify that valve opens.

Select valve Close at display and verify that valve closes. 


\begin{tabular}{|l|l|}
\hline $\begin{array}{c}\text { Checklist 4.2.5.8: } \\
\text { Instrumentation and Controls Test } \\
\text { Loop 250-1 High Pressure Pumps Suction Header Flush Valve }\end{array}$ & $\begin{array}{l}\text { Revision: 1 } \\
\text { Date: Nov. 21, 1997 }\end{array}$ \\
\hline $\begin{array}{l}\text { OHF Tank Contents Removal Project Cold Test } \\
\text { Oak Ridge National Laboratory, Oak Ridge, Tennessee }\end{array}$ & Page 2 of 2 \\
\hline Prepared by: CDM Federal Programs Corporation & \\
\hline
\end{tabular}

Comments:

Signature

Date

System Operator

I\&C Engineer

Project Engineer 


\begin{tabular}{|l|l|}
\hline $\begin{array}{c}\text { Checklist 4.2.5.9: } \\
\text { Instrumentation and Controls Test } \\
\text { Loop 250-2 Low Pressure Pumps Discharge Line Flush Valve }\end{array}$ & $\begin{array}{l}\text { Revision: 1 } \\
\text { Date: Nov. 21, 1997 }\end{array}$ \\
\hline $\begin{array}{l}\text { OHF Tank Contents Removal Project Cold Test } \\
\text { Oak Ridge National Laboratory, Oak Ridge, Tennessee }\end{array}$ & Page 1 of 2 \\
\hline Prepared by: CDM Federal Programs Corporation & \\
\hline
\end{tabular}

Initials Criteria

A. Review the associated displays for layout and completeness.

Display layout is correct and complete.

B. Point and display verification.
Verify valve field switch status indicates Local at display.
Select Computer Auto at display and verify status indicates Computer Auto at display.

Select Computer Manual at display and verify status indicates Computer Manual at display.

Change valve field switch to the Remote position and verify valve status changes to Remote at display.

C. Manual Control

With valve field switch in the Close position, Select valve Open at display and verify that valve does not Open.

With valve field switch in the Open position, Select valve Close at display and verify that valve does not Close.

Change valve field switch to the Remote position.

Select valve Open at display and verify that valve opens.

Select valve Close at display and verify that valve closes. 


\begin{tabular}{|l|l|}
\hline $\begin{array}{c}\text { Checklist 4.2.5.9: } \\
\text { Instrumentation and Controls Test } \\
\text { Loop 250-2 Low Pressure Pumps Discharge Line Flush Valve }\end{array}$ & $\begin{array}{l}\text { Revision: 1 } \\
\text { Date: Nov. 21, } 1997\end{array}$ \\
\hline $\begin{array}{l}\text { OHF Tank Contents Removal Project Cold Test } \\
\text { Oak Ridge National Laboratory, Oak Ridge, Tennessee }\end{array}$ & Page 2 of 2 \\
\hline Prepared by: CDM Federal Programs Corporation & \\
\hline
\end{tabular}

Comments:

Signature

Date

System Operator

I\&C Engineer

Project Engineer 
Checklist 4.2.5.10:

Revision: 0

Instrumentation and Controls Test

Date: Aug. 29, 1997

Loop 300 Recycle Tank Discharge Valve

OHF Tank Contents Removal Project Cold Test

Page 1 of 2

Oak Ridge National Laboratory, Oak Ridge, Tennessee

Prepared by: CDM Federal Programs Corporation

Initials

Criteria

A. Review the associated displays for layout and completeness.

Display layout is correct and complete.

B. Point and display verification.

Verify valve field switch status indicates Local at display.

Select Computer Auto at display and verify status indicates Computer Auto at display.

Select Computer Manual at display and verify status indicates Computer Manual at display.

Change valve field switch to the Remote position and verify valve status changes to Remote at display.

C. Manual Control

With valve field switch in the Close position, Select valve Open at display and verify that valve does not Open.

With valve field switch in the Open position, Select valve Close at display and verify that valve does not Close.

Change valve field switch to the Remote position.

Select valve Open at display and verify that valve opens.

Select valve Close at display and verify that valve closes. 
Checklist 4.2.5.10:

Revision: 0

Instrumentation and Controls Test

Date: Aug. 29, 1997

Loop 300 Recycle Tank Discharge Valve

OHF Tank Contents Removal Project Cold Test

Page 2 of 2

Oak Ridge National Laboratory, Oak Ridge, Tennessee

Prepared by: CDM Federal Programs Corporation

Comments:

Signature

Date

System Operator

I\&C Engineer

Project Engineer 
\begin{tabular}{|l|l}
\hline Checklist 4.2.5.11: & Revision: 1
\end{tabular}

Instrumentation and Controls Test

Date: Nov. 21, 1997

Loop 305 High Pressure Pumps Intake Line Pressure

and Recycle Valve

OHF Tank Contents Removal Project Cold Test

Page 1 of 2

Oak Ridge National Laboratory, Oak Ridge, Tennessee

Prepared by: CDM Federal Programs Corporation

Initials Criteria

A. Review the associated displays for layout and completeness.

- Display layout is correct and complete.

B. Point and display verification.

Verify valve field switch status indicates Local at display.

Change valve field switch to the Remote position and verify valve status changes to Remote at display.

Using discrete input simulation equipment, simulate an Intake Line Press Switch High state. Verify an alarm is generated at display.

Using discrete input simulation equipment, simulate an Intake Line Press Switch Normal state. Verify alarm is cleared at display.

Using analog input simulation equipment, simulate a pressure signal. Verify that the engineering units conversion is performed correctly. Verify a Low, High, and High High alarm is generated at display. Verify trend is functioning correctly.

C. Manual Control

With valve field switch in the Local position, enter a valve position set point of $100 \%$ at the display and verify that valve does not Open.

Change valve field switch to the Remote position. Enter a valve position set point of $100 \%$ at the display and verify that the valve position indication is $100 \%$ and that the valve status indicates Open.

Enter a valve position set point of $50 \%$ at the display and verify that the valve position indication is $50 \%$ and that the valve status indicates Transition. 


\begin{tabular}{|c|l|}
\hline $\begin{array}{c}\text { Checklist 4.2.5.11: } \begin{array}{c}\text { Instrumentation and Controls Test } \\
\text { Loop 305 High Pressure Pumps Intake Line Pressure } \\
\text { and Recycle Valve }\end{array} \\
\begin{array}{c}\text { OHF Tank Contents Removal Project Cold Test } \\
\text { Oak Ridge National Laboratory, Oak Ridge, Tennessee }\end{array}\end{array}$ & $\begin{array}{l}\text { Pevision: 1 } \\
\text { Date: Nov. 21, 1997 }\end{array}$ \\
\hline Prepared by: CDM Federal Programs Corporation & \\
\hline
\end{tabular}

Enter a valve position set point of $0 \%$ at the display and verify that the valve position indication is $0 \%$ and that valve status indicates Closed.

D. Computer Interlocks

Simulate a pressure signal above the High alarm limit. Verify that the valve position indication is proportional to the amount the pressure is above the high alarm limit.

Simulate a pressure signal below the High alarm limit. Verify that the valve position indication matches the manually entered valve position set point.

Comments:

Signature

Date

System Operator

I\&C Engineer

Project Engineer 


\begin{tabular}{|l|l|}
\hline $\begin{array}{c}\text { Checklist 4.2.5.12: } \\
\text { Instrumentation and Controls Test } \\
\text { Loop 320-1 High Pressure Transfer Pump 1 }\end{array}$ & $\begin{array}{l}\text { Revision: 1 } \\
\text { Date: Nov. 21, 1997 }\end{array}$ \\
\hline $\begin{array}{l}\text { OHF Tank Contents Removal Project Cold Test } \\
\text { Oak Ridge National Laboratory, Oak Ridge, Tennessee }\end{array}$ & Page 1 of 3 \\
\hline Prepared by: CDM Federal Programs Corporation & \\
\hline
\end{tabular}

Initials Criteria

A. Review the associated displays for layout and completeness.

Display layout is correct and complete.

B. Point and display verification.
- Verify pump field switch status indicates Local at display.
Verify pump status indicates Off at display.
Select Computer Auto at display and verify pump status indicates Computer Auto at display.

Select Computer Manual at display and verify pump status indicates Computer Manual at display.

Change pump field switch to the Remote position and verify pump status changes to Remote at display.

Using discrete input simulation equipment, simulate a VFD Drive Fail state.

Verify an alarm is generated at display.

Using discrete input simulation equipment, simulate a VFD Drive Fail return to Normal state. Verify alarm is cleared at display.

Using discrete input simulation equipment, simulate a Pump Pressure Shutdown state. Verify an alarm is generated at display.

Using discrete input simulation equipment, simulate a Pump Pressure Shutdown return to Normal state. Verify alarm is cleared at display. 


\begin{tabular}{|l|l|}
\hline $\begin{array}{c}\text { Checklist 4.2.5.12: } \\
\text { Instrumentation and Controls Test } \\
\text { Loop 320-1 High Pressure Transfer Pump 1 }\end{array}$ & $\begin{array}{l}\text { Revision: 1 } \\
\text { Date: Nov. 21, 1997 }\end{array}$ \\
\hline $\begin{array}{l}\text { OHF Tank Contents Removal Project Cold Test } \\
\text { Oak Ridge National Laboratory, Oak Ridge, Tennessee }\end{array}$ & Page 2 of 3 \\
\hline Prepared by: CDM Federal Programs Corporation & \\
\hline
\end{tabular}

C. Manual Control

With pump field switch in the Local position, Select pump start at display and verify that pump does not Run.

Change pump field switch to the Remote position. Select pump Start at display and verify that pump status changes to Run at display.

Enter a pump speed set point of $100 \%$ at the display and verify that the pump speed indication is $100 \%$ at display.

Enter a pump speed set point of $50 \%$ at the display and verify that the pump speed indication is $50 \%$ at display.

Enter a pump speed set point of $0 \%$ at the display and verify that the pump speed indication is $0 \%$ at display.

Select pump Stop at display and verify that pump status changes to Off at display.

D. Equipment Failure

Disable pump from running. Select pump Start at display and verify pump status indicates Off at display. After 10 seconds, verify that an equipment failure alarm is generated.

Select pump Start and verify PLC start output does not energize.

Select pump fail Reset at display. Enable pump to run and select pump Start at display and verify pump status changes to Run at display. Select pump Stop at display.

E. Interlocks

Select pump Start at display. With pump confirmed running, simulate a VFD Drive Fail condition. Verify a VFD Drive Fail Alarm is generated and the pump is shut off. 
Checklist 4.2.5.12:

Instrumentation and Controls Test

Revision: 1

Loop 320-1 High Pressure Transfer Pump 1

OHF Tank Contents Removal Project Cold Test

Date: Nov. 21, 1997

Oak Ridge National Laboratory, Oak Ridge, Tennessee

Prepared by: CDM Federal Programs Corporation

Remove VFD Drive Fail condition. Select pump Start at display. With pump confirmed running, simulate a Pump Pressure Shutdown condition. Verify a Pump Pressure Shutdown Alarm is generated and the pump is shut off.

Remove Pump Pressure Shutdown condition.

F. Auto Mode

With pump in Computer Manual start/stop mode, Select pump Start at display. Enter a $50 \%$ scale pressure set point at the pump speed controller.

With pump confirmed running, select Computer Auto Pressure Control at display. Verify pump status indicates Computer Auto Pressure Control at display.

Simulate high transfer line pressure. Set pressure to $50 \%$ scale and verify that pump speed remains constant.

Set pressure to $75 \%$ scale and verify that pump speed begins decreasing.

Set pressure to $25 \%$ scale and verify that pump speed begins increasing.

Select pump Stop at display. Verify pump speed is $0 \%$.

Comments:

Signature

Date

System Operator

I\&C Engineer

Project Engineer 


\begin{tabular}{|l|l|}
\hline $\begin{array}{c}\text { Checklist 4.2.5.13: } \\
\text { Instrumentation and Controls Test } \\
\text { Loop 320-2 High Pressure Transfer Pump 2 }\end{array}$ & $\begin{array}{l}\text { Revision: 1 } \\
\text { Date: Nov. 21, 1997 }\end{array}$ \\
\hline $\begin{array}{l}\text { OHF Tank Contents Removal Project Cold Test } \\
\text { Oak Ridge National Laboratory, Oak Ridge, Tennessee }\end{array}$ & Page 1 of 3 \\
\hline Prepared by: CDM Federal Programs Corporation & \\
\hline
\end{tabular}

Initials Criteria

A. Review the associated displays for layout and completeness.

Display layout is correct and complete.

B. Point and display verification.

Verify pump field switch status indicates Local at display.

Verify pump status indicates Off at display.

Select Computer Auto at display and verify pump status indicates Computer Auto at display.

Select Computer Manual at display and verify pump status indicates Computer Manual at display.

Change pump field switch to the Remote position and verify pump status changes to Remote at display.

Using discrete input simulation equipment, simulate a VFD Drive Fail state.

Verify an alarm is generated at display.

Using discrete input simulation equipment, simulate a VFD Drive Fail return to Normal state. Verify alarm is cleared at display.

Using discrete input simulation equipment, simulate a Pump Pressure Shutdown state. Verify an alarm is generated at display.

Using discrete input simulation equipment, simulate a Pump Pressure Shutdown return to Normal state. Verify alarm is cleared at display. 


\begin{tabular}{|l|l|}
\hline $\begin{array}{c}\text { Checklist 4.2.5.13: } \\
\text { Instrumentation and Controls Test } \\
\text { Loop 320-2 High Pressure Transfer Pump 2 }\end{array}$ & $\begin{array}{l}\text { Revision: 1 } \\
\text { Date: Nov. 21, 1997 }\end{array}$ \\
\hline $\begin{array}{l}\text { OHF Tank Contents Removal Project Cold Test } \\
\text { Oak Ridge National Laboratory, Oak Ridge, Tennessee }\end{array}$ & Page 2 of 3 \\
\hline Prepared by: CDM Federal Programs Corporation & \\
\hline
\end{tabular}

\section{Manual Control}

With pump field switch in the Local position, Select pump start at display and verify that pump does not Run.

Change pump field switch to the Remote position. Select pump Start at display and verify that pump status changes to Run at display.

Enter a pump speed set point of $100 \%$ at the display and verify that the pump speed indication is $100 \%$ at display.

Enter a pump speed set point of $50 \%$ at the display and verify that the pump speed indication is $50 \%$ at display.

Enter a pump speed set point of $0 \%$ at the display and verify that the pump speed indication is $0 \%$ at display.

Select pump Stop at display and verify that pump status changes to Off at display.

D. Equipment Failure

Disable pump from running. Select pump Start at display and verify pump status indicates Off at display. After 10 seconds, verify that an equipment failure alarm is generated.

Select pump Start and verify PLC start output does not energize.

Select pump fail Reset at display. Enable pump to run and select pump Start at display and verify pump status changes to Run at display. Select pump Stop at display.

E. Interlocks

Select pump Start at display. With pump confirmed running, simulate a VFD Drive Fail condition. Verify a VFD Drive Fail Alarm is generated and the pump is shut off. 
Checklist 4.2.5.13:

Instrumentation and Controls Test

Revision: 1

Loop 320-2 High Pressure Transfer Pump 2

OHF Tank Contents Removal Project Cold Test

Date: Nov. 21, 1997

Oak Ridge National Laboratory, Oak Ridge, Tennessee

Prepared by: CDM Federal Programs Corporation

Remove VFD Drive Fail condition. Select pump Start at display. With pump confirmed running, simulate a Pump Pressure Shutdown condition. Verify a Pump Pressure Shutdown Alarm is generated and the pump is shut off.

Remove Pump Pressure Shutdown condition.

F. Auto Mode

With pump in Computer Manual start/stop mode, Select pump Start at display. Enter a $50 \%$ scale pressure set point at the pump speed controller.

With pump confirmed running, select Computer Auto Pressure Control at display. Verify pump status indicates Computer Auto Pressure Control at display.

Simulate high transfer line pressure. Set pressure to $50 \%$ scale and verify that pump speed remains constant.

Set pressure to $75 \%$ scale and verify that pump speed begins decreasing.

Set pressure to $25 \%$ scale and verify that pump speed begins increasing.

Select pump Stop at display. Verify pump speed is $0 \%$.

Comments:

Signature

Date

System Operator

I\&C Engineer

Project Engineer 


\begin{tabular}{|l|l|}
\hline $\begin{array}{c}\text { Checklist 4.2.5.14: } \\
\text { Instrumentation and Controls Test } \\
\text { Loop 330 High Pressure Transfer Line Pressure }\end{array}$ & $\begin{array}{l}\text { Revision: } 0 \\
\text { Date: Aug. 29, 1997 }\end{array}$ \\
\hline $\begin{array}{l}\text { OHF Tank Contents Removal Project Cold Test } \\
\text { Oak Ridge National Laboratory, Oak Ridge, Tennessee }\end{array}$ & Page 1 of 1 \\
\hline Prepared by: CDM Federal Programs Corporation & \\
\hline
\end{tabular}

Initials Criteria

A. Review the associated displays for layout and completeness.

Display layout is correct and complete.

B. Point and display verification

Using analog input simulation equipment, simulate a pressure signal. Verify that the engineering units conversion is performed correctly. Verify a High and High High alarm is generated at display. Verify trend is functioning correctly.

Using discrete input simulation equipment, simulate a High Pressure Transfer Line Pressure Switch High state. Verify an alarm is generated at display.

Using discrete input simulation equipment, simulate a High Pressure Transfer Line Pressure Switch Normal state. Verify alarm is cleared at display.

Comments:

Signature Date

System Operator

I\&C Engineer

Project Engineer 
Checklist 4.2.5.15: Instrumentation and Controls Test Revision: 1 Loop 340-1 High Pressure Recycle Valve

OHF Tank Contents Removal Project Cold Test Date: Nov. 21, 1997

Oak Ridge National Laboratory, Oak Ridge, Tennessee

Page 1 of 2

Prepared by: CDM Federal Programs Corporation

Initials Criteria

A. Review the associated displays for layout and completeness.

Display layout is correct and complete.

B. Point and display verification

Verify valve field switch status indicates Local at display.

Change valve field switch to the Remote position and verify valve status changes to Remote at display.

C. Manual Control

With valve field switch in the Local position, enter a valve position set point of $100 \%$ at the display and verify that valve does not Open.

Change valve field switch to the Remote position.

Enter a valve position set point of $100 \%$ at the display and verify that the valve position indication is $100 \%$ and that the valve status indicates Open.

Enter a valve position set point of $50 \%$ at the display and verify that the valve position indication is $50 \%$ and that the valve status indicates Transition.

Enter a valve position set point of $0 \%$ at the display and verify that the valve position indication is $0 \%$ and that valve status indicates Closed.

D. Computer Interlocks

Simulate a Loop 330 pressure signal above the High alarm limit. Verify that the valve position indication is proportional to the amount the pressure is above the High alarm limit. 


\begin{tabular}{|l|l|}
\hline $\begin{array}{c}\text { Checklist 4.2.5.15: } \\
\text { Instrumentation and Controls Test } \\
\text { Loop 340-1 High Pressure Recycle Valve }\end{array}$ & $\begin{array}{l}\text { Revision: 1 } \\
\text { Date: Nov. 21, 1997 }\end{array}$ \\
\hline $\begin{array}{l}\text { OHF Tank Contents Removal Project Cold Test } \\
\text { Oak Ridge National Laboratory, Oak Ridge, Tennessee }\end{array}$ & Page 2 of 2 \\
\hline Prepared by: CDM Federal Programs Corporation & \\
\hline
\end{tabular}

Simulate a Loop 330 pressure signal below the High alarm limit. Verify that the valve position indication matches the manually entered valve position set point.

Comments:

Signature

Date

System Operator

I\&C Engineer

Project Engineer 


\begin{tabular}{|l|l|}
\hline $\begin{array}{c}\text { Checklist 4.2.5.16: } \\
\text { Instrumentation and Controls Test } \\
\text { Loop 340-2 MVST Discharge Valve }\end{array}$ & $\begin{array}{l}\text { Revision: 1 } \\
\text { Date: Nov. 21, } 1997\end{array}$ \\
\hline $\begin{array}{l}\text { OHF Tank Contents Removal Project Cold Test } \\
\text { Oak Ridge National Laboratory, Oak Ridge, Tennessee }\end{array}$ & Page 1 of 2 \\
\hline Prepared by: CDM Federal Programs Corporation & \\
\hline
\end{tabular}

Initials Criteria

A. Review the associated displays for layout and completeness.

B. Point and display verification

Display layout is correct and complete.

Verify valve field switch status indicates Local at display.

Verify valve status indicates Computer Manual at display.

Change valve field switch to the Remote position and verify valve status changes to Remote at display.

C. Manual Control

With valve field switch in the Local position, enter a valve position set point of $100 \%$ at the display and verify that valve does not Open.

Change valve field switch to the Remote position. Enter a valve position set point of $100 \%$ at the display and verify that the valve position indication is $100 \%$ and that the valve status indicates Open.

Enter a valve position set point of $50 \%$ at the display and verify that the valve position indication is $50 \%$ and that the valve status indicates Transition.

Enter a valve position set point of $0 \%$ at the display and verify that the valve position indication is $0 \%$ and that valve status indicates Closed.

D. Auto Mode

Enter a 50\% scale flow set point at the valve flow controller. Select Computer Auto Flow Control at display. Verify valve status indicates Computer Auto Flow Control at display. 


\begin{tabular}{|l|l|}
\hline $\begin{array}{c}\text { Checklist 4.2.5.16: } \\
\text { Instrumentation and Controls Test } \\
\text { Loop 340-2 MVST Discharge Valve }\end{array}$ & $\begin{array}{l}\text { Revision: 1 } \\
\text { Date: Nov. 21, 1997 }\end{array}$ \\
\hline $\begin{array}{l}\text { OHF Tank Contents Removal Project Cold Test } \\
\text { Oak Ridge National Laboratory, Oak Ridge, Tennessee }\end{array}$ & Page 2 of 2 \\
\hline Prepared by: CDM Federal Programs Corporation & \\
\hline
\end{tabular}

In Computer Auto Flow Control, valve is clamped Closed until Operator confirms MVST discharge. Simulate operator MVST discharge selection. With MVST discharge not enabled, simulate Loop 345 flow. Set flow to $0 \%$ scale and verify that valve position indication is $0 \%$.

With MVST discharge enabled, simulate Loop 345 flow. Set flow to $25 \%$ scale and verify that valve begins opening.

Set flow to $75 \%$ scale and verify that valve begins closing.

Set flow to $50 \%$ scale and verify that valve position remains constant.

Comments:

Signature

Date

System Operator

I\&C Engineer

Project Engineer 
Checklist 4.2.5.17:

Instrumentation and Controls Test

Revision: 1

Loop 345 MVST Discharge Flow

OHF Tank Contents Removal Project Cold Test

Date: Nov. 21, 1997

Oak Ridge National Laboratory, Oak Ridge, Tennessee

Page 1 of 1

Prepared by: CDM Federal Programs Corporation

Initials Criteria

A. Review the associated displays for layout and completeness.

Display layout is correct and complete.

B. Point and display verification

Using analog input simulation equipment, simulate a flow signal. Verify that the engineering units conversion is performed correctly. Verify trend is functioning correctly.

Verify flow totalization is working. Select flow totalization Reset at display and confirm flow total is set to 0 .

Comments:

Signature

Date

System Operator

I\&C Engineer

Project Engineer 
\begin{tabular}{|l|l}
\hline Checklist 4.2.5.18: & Revision: 1
\end{tabular}

Instrumentation and Controls Test $\quad$ Date: Nov. 21, 1997

Loop 350-1 Strainer Valve 1

OHF Tank Contents Removal Project Cold Test

Page 1 of 2

Oak Ridge National Laboratory, Oak Ridge, Tennessee

Prepared by: CDM Federal Programs Corporation

Initials Criteria

A. Review the associated displays for layout and completeness.

Display layout is correct and complete.

B. Point and display verification

Verify valve field switch status indicates Local at display.

Change valve field switch to the Remote position and verify valve status changes to Remote at display.

Select Computer Auto at display and verify status indicates Computer Auto at display.

Select Computer Manual at display and verify status indicates Computer Manual at display.

C. Manual Control

With valve field switch in the Close position, Select valve Open at display and verify that valve does not Open.

With valve field switch in the Open position, Select valve Close at display and verify that valve does not Close.

Change valve field switch to the Remote position. Select valve Open at display and verify that valve opens.

Select valve Close at display and verify that valve closes. 
Checklist 4.2.5.18:

Revision: 1

Instrumentation and Controls Test

Date: Nov. 21, 1997

Loop 350-1 Strainer Valve 1

OHF Tank Contents Removal Project Cold Test

Page 2 of 2

Oak Ridge National Laboratory, Oak Ridge, Tennessee

Prepared by: CDM Federal Programs Corporation

Comments:

Signature

Date

System Operator

I\&C Engineer

Project Engineer 
Checklist 4.2.5.19:

Instrumentation and Controls Test

Revision: 1

Loop 350-2 Strainer Valve 2

OHF Tank Contents Removal Project Cold Test

Date: Nov. 21, 1997

Oak Ridge National Laboratory, Oak Ridge, Tennessee

Prepared by: CDM Federal Programs Corporation

Initials

Criteria

A. Review the associated displays for layout and completeness.

Display layout is correct and complete.

B. Point and display verification

Verify valve field switch status indicates Local at display.

Change valve field switch to the Remote position and verify valve status changes to Remote at display.

Select Computer Auto at display and verify status indicates Computer Auto at display.

Select Computer Manual at display and verify status indicates Computer Manual at display.

C. Manual Control

With valve field switch in the Close position, Select valve Open at display and verify that valve does not Open.

With valve field switch in the Open position, Select valve Close at display and verify that valve does not Close.

Change valve field switch to the Remote position. Select valve Open at display and verify that valve opens.

Select valve Close at display and verify that valve closes. 


\begin{tabular}{|l|l|}
\hline $\begin{array}{c}\text { Checklist 4.2.5.19: } \\
\text { Instrumentation and Controls Test } \\
\text { Loop 350-2 Strainer Valve 2 }\end{array}$ & $\begin{array}{l}\text { Revision: 1 } \\
\text { Date: Nov. 21, } 1997\end{array}$ \\
\hline $\begin{array}{l}\text { OHF Tank Contents Removal Project Cold Test } \\
\text { Oak Ridge National Laboratory, Oak Ridge, Tennessee }\end{array}$ & Page 2 of 2 \\
\hline Prepared by: CDM Federal Programs Corporation & \\
\hline
\end{tabular}

Comments:

Signature

Date

System Operator

I\&C Engineer

Project Engineer 


\begin{tabular}{|l|l|}
\hline $\begin{array}{c}\text { Checklist 4.2.5.20: } \\
\text { Instrumentation and Controls Test } \\
\text { Loop 360-1 Strainer Drain Valve 1 }\end{array}$ & $\begin{array}{l}\text { Revision: 1 } \\
\text { Date: Nov. 21, } 1997\end{array}$ \\
\hline $\begin{array}{l}\text { OHF Tank Contents Removal Project Cold Test } \\
\text { Oak Ridge National Laboratory, Oak Ridge, Tennessee }\end{array}$ & Page 1 of 2 \\
\hline Prepared by: CDM Federal Programs Corporation & \\
\hline
\end{tabular}

Initials Criteria

A. Review the associated displays for layout and completeness.

Display layout is correct and complete.

B. Point and display verification

Verify valve field switch status indicates Local at display.

Change valve field switch to the Remote position and verify valve status changes to Remote at display.

Select Computer Auto at display and verify valve status indicates Computer Auto at display.

Select Computer Manual at display and verify valve status indicates Computer Manual at display.

Using analog input simulation equipment, simulate a strainer differential pressure signal. (Loop 330 minus Loop 663 pressure). Verify that the engineering units conversion is performed correctly. Verify a High alarm is generated at display.

C. Manual Control

With valve field switch in the Close position, Select valve Open at display and verify that valve does not Open.

With valve field switch in the Open position, Select valve Close at display and verify that valve does not Close.

Change valve field switch to the Remote position. Select valve Open at display and verify that valve opens.

Select valve Close at display and verify that valve closes. 
Checklist 4.2.5.20:

Revision: 1

Instrumentation and Controls Test

Date: Nov. 21, 1997

Loop 360-1 Strainer Drain Valve 1

OHF Tank Contents Removal Project Cold Test

Page 2 of 2

Oak Ridge National Laboratory, Oak Ridge, Tennessee

Prepared by: CDM Federal Programs Corporation

Comments:

Signature

Date

System Operator

I\&C Engineer

Project Engineer 


\begin{tabular}{|l|l|}
\hline $\begin{array}{l}\text { Checklist 4.2.5.21: } \\
\text { Instrumentation and Controls Test } \\
\text { Loop 360-2 Strainer Drain Valve 2 }\end{array}$ & $\begin{array}{l}\text { Revision: 1 } \\
\text { Date: Nov. 21, } 1997\end{array}$ \\
\hline $\begin{array}{l}\text { OHF Tank Contents Removal Project Cold Test } \\
\text { Oak Ridge National Laboratory, Oak Ridge, Tennessee }\end{array}$ & Page 1 of 2 \\
\hline Prepared by: CDM Federal Programs Corporation & \\
\hline
\end{tabular}

Initials Criteria

A. Review the associated displays for layout and completeness.

Display layout is correct and complete.

B. Point and display verification

Verify valve field switch status indicates Local at display.

Change valve field switch to the Remote position and verify valve status changes to Remote at display.

Select Computer Auto at display and verify valve status indicates Computer Auto at display.

Select Computer Manual at display and verify valve status indicates Computer Manual at display.

Using analog input simulation equipment, simulate a strainer differential pressure signal. (Loop 330 minus Loop 663 pressure). Verify that the engineering units conversion is performed correctly. Verify a High alarm is generated at display.

C. Manual Control

With valve field switch in the Close position, Select valve Open at display and verify that valve does not Open.

With valve field switch in the Open position, Select valve Close at display and verify that valve does not Close.

Change valve field switch to the Remote position. Select valve Open at display and verify that valve opens.

Select valve Close at display and verify that valve closes. 


\begin{tabular}{|l|l|}
\hline $\begin{array}{c}\text { Checklist 4.2.5.21: } \\
\text { Instrumentation and Controls Test } \\
\text { Loop 360-2 Strainer Drain Valve 2 }\end{array}$ & $\begin{array}{l}\text { Revision: 1 } \\
\text { Date: Nov. 21, 1997 }\end{array}$ \\
\hline $\begin{array}{l}\text { OHF Tank Contents Removal Project Cold Test } \\
\text { Oak Ridge National Laboratory, Oak Ridge, Tennessee }\end{array}$ & Page 2 of 2 \\
\hline Prepared by: CDM Federal Programs Corporation & \\
\hline
\end{tabular}

Comments:

Signature

Date

System Operator

I\&C Engineer

Project Engineer 


\begin{tabular}{|l|l|}
\hline $\begin{array}{c}\text { Checklist 4.2.5.22: } \\
\text { Instrumentation and Controls Test } \\
\text { Loop 410-1 Old Hydrofracture Tank Pump 1 }\end{array}$ & $\begin{array}{l}\text { Revision: 1 } \\
\text { Date: Nov. 21, 1997 }\end{array}$ \\
\hline $\begin{array}{l}\text { OHF Tank Contents Removal Project Cold Test } \\
\text { Oak Ridge National Laboratory, Oak Ridge, Tennessee }\end{array}$ & Page 1 of 2 \\
\hline Prepared by: CDM Federal Programs Corporation & \\
\hline
\end{tabular}

Initials Criteria

A. Review the associated displays for layout and completeness.

Display layout is correct and complete.

B. Point and display verification

Verify pump field switch status indicates Local at display.

Verify pump status indicates Off at display.

Select Computer Auto at display and verify pump status indicates Computer Auto at display.

Select Computer Manual at display and verify pump status indicates Computer Manual at display.

Change pump field switch to the Remote position and verify pump status changes to Remote at display.

C. Manual Control

With pump field switch in the Local position, Select pump Start at display and verify that pump does not Run.

Change pump field switch to the Remote position.

Select pump Start at display and verify that pump status changes to Run at display.

Select pump Stop at display and verify that pump status changes to Off at display. 
Checklist 4.2.5.22:

Instrumentation and Controls Test Loop 410-1 Old Hydrofracture Tank Pump 1

OHF Tank Contents Removal Project Cold Test Revision: 1

Date: Nov. 21, 1997

Oak Ridge National Laboratory, Oak Ridge, Tennessee

Prepared by: CDM Federal Programs Corporation

D. Equipment Failure

Disable pump from running. Select pump Start at display and verify pump status indicates Off at display. After 10 seconds, verify that an equipment failure alarm is generated.

Select pump Start and verify PLC start output does not energize.

Select pump fail Reset at display. Enable pump to run and select pump Start at display and verify pump status changes to Run at display. Select pump Stop at display.

E. Interlocks

Select pump Start at display. With pump confirmed running, simulate a Loop 445-1 High High Recycle Tank Level condition. Verify a High High Recycle Tank Level Alarm is generated and the pump is shut off.

Return Loop 445-1 level to normal. Verify pump does not restart.

Comments:

Signature

Date

System Operator

I\&C Engineer

Project Engineer 


\begin{tabular}{|l|l|}
\hline $\begin{array}{c}\text { Checklist 4.2.5.23: } \\
\text { Instrumentation and Controls Test } \\
\text { Loop 410-2 Old Hydrofracture Tank Pump 2 }\end{array}$ & $\begin{array}{l}\text { Revision: 1 } \\
\text { Date: Nov. 21, 1997 }\end{array}$ \\
\hline $\begin{array}{l}\text { OHF Tank Contents Removal Project Cold Test } \\
\text { Oak Ridge National Laboratory, Oak Ridge, Tennessee }\end{array}$ & Page 1 of 2 \\
\hline Prepared by: CDM Federal Programs Corporation & \\
\hline
\end{tabular}

Initials Criteria

A. Review the associated displays for layout and completeness.

Display layout is correct and complete.

B. Point and display verification

Verify pump field switch status indicates Local at display.

Verify pump status indicates Off at display.

Select Computer Auto at display and verify pump status indicates Computer Auto at display.

Select Computer Manual at display and verify pump status indicates Computer Manual at display.

Change pump field switch to the Remote position and verify pump status changes to Remote at display.

C. Manual Control

With pump field switch in the Local position, Select pump Start at display and verify that pump does not Run.

Change pump field switch to the Remote position.

Select pump Start at display and verify that pump status changes to Run at display.

Select pump Stop at display and verify that pump status changes to Off at display. 


\begin{tabular}{|l|l|}
\hline $\begin{array}{c}\text { Checklist 4.2.5.23: } \\
\text { Instrumentation and Controls Test } \\
\text { Loop 410-2 Old Hydrofracture Tank Pump 2 }\end{array}$ & $\begin{array}{l}\text { Revision: 1 } \\
\text { Date: Nov. 21, 1997 }\end{array}$ \\
\hline $\begin{array}{l}\text { OHF Tank Contents Removal Project Cold Test } \\
\text { Oak Ridge National Laboratory, Oak Ridge, Tennessee }\end{array}$ & Page 2 of 2 \\
\hline Prepared by: CDM Federal Programs Corporation & \\
\hline
\end{tabular}

D. Equipment Failure

Disable pump from running. Select pump Start at display and verify pump status indicates Off at display. After 10 seconds, verify that an equipment failure alarm is generated.

Select pump Start and verify PLC start output does not energize.

Select pump fail Reset at display. Enable pump to run and select pump Start at display and verify pump status changes to Run at display. Select pump Stop at display.

E. Interlocks

Select pump Start at display. With pump confirmed running, simulate a Loop 445-1 High High Recycle Tank Level condition. . Verify a High High Recycle Tank Level Alarm is generated and the pump is shut off.

Return Loop 445-1 level to normal. Verify pump does not restart.

Comments:

Signature

Date

System Operator

I\&C Engineer

Project Engineer 
Checklist 4.2.5.24:

Instrumentation and Controls Test

Revision: 1

Date: Nov. 21, 1997

Loop 410-1 Tank 1 Pump Discharge Valve 1

OHF Tank Contents Removal Project Cold Test

Page 1 of 2

Oak Ridge National Laboratory, Oak Ridge, Tennessee

Prepared by: CDM Federal Programs Corporation

Initials Criteria

A. Review the associated displays for layout and completeness.

Display layout is correct and complete.

B. Point and display verification

Verify valve field switch status indicates Local at display.

Change valve field switch to the Remote position and verify valve status changes to Remote at display.

Select Computer Auto at display and verify status indicates Computer Auto at display.

Select Computer Manual at display and verify status indicates Computer Manual at display.

C. Manual Control

With valve field switch in the Close position, Select valve Open at display and verify that valve does not Open.

With valve field switch in the Open position, Select valve Close at display and verify that valve does not Close.

Change valve field switch to the Remote position. Select valve Open at display and verify that valve opens.

Select valve Close at display and verify that valve closes. 


\begin{tabular}{|l|l|}
\hline $\begin{array}{c}\text { Checklist 4.2.5.24: } \\
\text { Instrumentation and Controls Test } \\
\text { Loop 410-1 Tank 1 Pump Discharge Valve 1 }\end{array}$ & $\begin{array}{l}\text { Revision: 1 } \\
\text { Date: Nov. 21, 1997 }\end{array}$ \\
\hline $\begin{array}{l}\text { OHF Tank Contents Removal Project Cold Test } \\
\text { Oak Ridge National Laboratory, Oak Ridge, Tennessee }\end{array}$ & Page 2 of 2 \\
\hline Prepared by: CDM Federal Programs Corporation & \\
\hline
\end{tabular}

Comments:

Signature

Date

System Operator

I\&C Engineer

Project Engineer 


\begin{tabular}{|l|l|}
\hline $\begin{array}{l}\text { Checklist 4.2.5.25: } \\
\text { Instrumentation and Controls Test } \\
\text { Loop 410-2 Tank 1 Pump Discharge Valve 2 }\end{array}$ & $\begin{array}{l}\text { Revision: 1 } \\
\text { Date: Nov. 21, 1997 }\end{array}$ \\
\hline $\begin{array}{l}\text { OHF Tank Contents Removal Project Cold Test } \\
\text { Oak Ridge National Laboratory, Oak Ridge, Tennessee }\end{array}$ & Page 1 of 2 \\
\hline Prepared by: CDM Federal Programs Corporation & \\
\hline
\end{tabular}

Initials Criteria

A. Review the associated displays for layout and completeness.

Display layout is correct and complete.

B. Point and display verification

Verify valve field switch status indicates Local at display.

Change valve field switch to the Remote position and verify valve status changes to Remote at display.

Select Computer Auto at display and verify status indicates Computer Auto at display.

Select Computer Manual at display and verify status indicates Computer Manual at display.

C. Manual Control

With valve field switch in the Close position, Select valve Open at display and verify that valve does not Open.

With valve field switch in the Open position, Select valve Close at display and verify that valve does not Close.

Change valve field switch to the Remote position. Select valve Open at display and verify that valve opens.

Select valve Close at display and verify that valve closes. 


\begin{tabular}{|l|l|}
\hline $\begin{array}{c}\text { Checklist 4.2.5.25: } \\
\text { Instrumentation and Controls Test } \\
\text { Loop 410-2 Tank 1 Pump Discharge Valve 2 }\end{array}$ & $\begin{array}{l}\text { Revision: 1 } \\
\text { Date: Nov. 21, } 1997\end{array}$ \\
\hline $\begin{array}{l}\text { OHF Tank Contents Removal Project Cold Test } \\
\text { Oak Ridge National Laboratory, Oak Ridge, Tennessee }\end{array}$ & Page 2 of 2 \\
\hline Prepared by: CDM Federal Programs Corporation & \\
\hline
\end{tabular}

Comments:

Signature

Date

System Operator

I\&C Engineer

Project Engineer 
Checklist 4.2.5.26:

Revision: 1

Instrumentation and Controls Test

Date: Nov. 21, 1997

Loop 445 Bubbler System Air Pressure

OHF Tank Contents Removal Project Cold Test

Page 1 of 1

Oak Ridge National Laboratory, Oak Ridge, Tennessee

Prepared by: CDM Federal Programs Corporation

Initials Criteria

A. Review the associated displays for layout and completeness.

Display layout is correct and complete.

B. Point and display verification

Using discrete input simulation equipment, simulate a pressure switch Low state.

Verify an alarm is generated at display.

Using discrete input simulation equipment, simulate a pressure switch return to Normal state. Verify alarm is cleared at display.

Comments:

Signature

Date

System Operator

I\&C Engineer

Project Engineer 


\begin{tabular}{|l|l|}
\hline $\begin{array}{c}\text { Checklist 4.2.5.27: } \\
\text { Instrumentation and Controls Test } \\
\text { Loop 445-1 Recycle Tank Level (Bubbler System) }\end{array}$ & $\begin{array}{l}\text { Revision: 1 } \\
\text { Date: Nov. 21, 1997 }\end{array}$ \\
\hline $\begin{array}{l}\text { OHF Tank Contents Removal Project Cold Test } \\
\text { Oak Ridge National Laboratory, Oak Ridge, Tennessee }\end{array}$ & Page 1 of 1 \\
\hline Prepared by: CDM Federal Programs Corporation & \\
\hline
\end{tabular}

Initials Criteria

A. Review the associated displays for layout and completeness.

Display layout is correct and complete.

B. Point and display verification

Using analog input simulation equipment, simulate a level signal. Verify that the engineering units conversion is performed correctly. Verify a Low, High, and High High alarm is generated at display. Verify trend is functioning correctly.

C. Manual Control

Select blow down valve Open at display and verify that valve opens.

Select blow down valve Close at display and verify that valve closes.

Comments:

Signature

Date

System Operator

I\&C Engineer

Project Engineer 
Checklist 4.2.5.28:

Instrumentation and Controls Test

Revision: 1

Date: Nov. 21, 1997

Loop 445-2 Old Hydrofracture Tank Level (Bubbler System)

OHF Tank Contents Removal Project Cold Test

Page 1 of 1

Oak Ridge National Laboratory, Oak Ridge, Tennessee

Prepared by: CDM Federal Programs Corporation

Initials Criteria

A. Review the associated displays for layout and completeness.

Display layout is correct and complete.

B. Point and display verification

Using analog input simulation equipment, simulate a level signal. Verify that the engineering units conversion is performed correctly. Verify a Low, High, and High High alarm is generated at display. Verify trend is functioning correctly.

C. Manual Control

Select blow down valve Open at display and verify that valve opens.

Select blow down valve Close at display and verify that valve closes.

Comments:

Signature

Date

System Operator

I\&C Engineer

Project Engineer 


\begin{tabular}{|l|l|}
\hline $\begin{array}{c}\text { Checklist 4.2.5.29: } \\
\text { Instrumentation and Controls Test } \\
\text { Loop 445-3 Old Hydrofracture Tank Level (Bubbler System) }\end{array}$ & $\begin{array}{l}\text { Revision: 1 } \\
\text { Date: Nov. 21, 1997 }\end{array}$ \\
\hline $\begin{array}{l}\text { OHF Tank Contents Removal Project Cold Test } \\
\text { Oak Ridge National Laboratory, Oak Ridge, Tennessee }\end{array}$ & Page 1 of 1 \\
\hline Prepared by: CDM Federal Programs Corporation & \\
\hline
\end{tabular}

Initials Criteria

A. Review the associated displays for layout and completeness.

Display layout is correct and complete.

B. Point and display verification

Using analog input simulation equipment, simulate a level signal. Verify that the engineering units conversion is performed correctly. Verify a Low, High, and High High alarm is generated at display. Verify trend is functioning correctly.

C. Manual Control

Select blow down valve Open at display and verify that valve opens.

Select blow down valve Close at display and verify that valve closes.

Comments:

Signature

Date

System Operator

I\&C Engineer

Project Engineer 


\begin{tabular}{|l|l|}
\hline $\begin{array}{c}\text { Checklist 4.2.5.30: } \\
\text { Instrumentation and Controls Test } \\
\text { Loop 450 Low Pressure Transfer Flow }\end{array}$ & $\begin{array}{l}\text { Revision: 1 } \\
\text { Date: Nov. 21, 1997 }\end{array}$ \\
\hline $\begin{array}{l}\text { OHF Tank Contents Removal Project Cold Test } \\
\text { Oak Ridge National Laboratory, Oak Ridge, Tennessee }\end{array}$ & Page 1 of 1 \\
\hline Prepared by: CDM Federal Programs Corporation & \\
\hline
\end{tabular}

Initials Criteria

A. Review the associated displays for layout and completeness.

Display layout is correct and complete.

B. Point and display verification

Using analog input simulation equipment, simulate a flow signal. Verify that the engineering units conversion is performed. Verify trend is functioning correctly.

Verify flow totalization is working. Select flow totalization Reset at display and confirm flow total is set to 0 .

Comments:

Signature

Date

System Operator

I\&C Engineer

Project Engineer 


\begin{tabular}{|l|l|}
\hline $\begin{array}{c}\text { Checklist 4.2.5.31: } \\
\text { Instrumentation and Controls Test } \\
\text { Loop 455 Low Pressure Transfer Throttling Valve }\end{array}$ & $\begin{array}{l}\text { Revision: 1 } \\
\text { Date: Nov. 21, } 1997\end{array}$ \\
\hline $\begin{array}{l}\text { OHF Tank Contents Removal Project Cold Test } \\
\text { Oak Ridge National Laboratory, Oak Ridge, Tennessee }\end{array}$ & Page 1 of 2 \\
\hline Prepared by: CDM Federal Programs Corporation & \\
\hline
\end{tabular}

Initials Criteria

A. Review the associated displays for layout and completeness.

Display layout is correct and complete.

B. Point and display verification

Verify valve field switch status indicates Local at display.
Verify valve status indicates Computer Manual at display.
$\begin{aligned} & \text { Change valve field switch to the Remote position and verify valve status changes } \\ & \text { to Remote at display. }\end{aligned}$

C. Manual Control

With valve field switch in the Local position, enter a valve position set point of $100 \%$ at the display and verify that valve does not Open.

Change valve field switch to the Remote position. Enter a valve position set point of $100 \%$ at the display and verify that the valve position indication is $100 \%$ and that the valve status indicates Open.

Enter a valve position set point of $50 \%$ at the display and verify that the valve position indication is $50 \%$ and that the valve status indicates Transition.

Enter a valve position set point of $0 \%$ at the display and verify that the valve position indication is $0 \%$ and that valve status indicates Closed.

D. Auto Mode

Valve is used to control level in recycle tank. Enter a 50\% scale level set point at the valve level controller. Select Computer Auto Level Control at display. Verify valve status indicates Computer Auto Level Control at display. 
Checklist 4.2.5.31:

Revision: 1

Instrumentation and Controls Test

Date: Nov. 21, 1997

Loop 455 Low Pressure Transfer Throttling Valve

OHF Tank Contents Removal Project Cold Test

Page 2 of 2

Oak Ridge National Laboratory, Oak Ridge, Tennessee

Prepared by: CDM Federal Programs Corporation

Simulate level. Set level to $25 \%$ scale and verify that valve begins opening.

Set level to $75 \%$ scale and verify that valve begins closing.

Set level to $50 \%$ scale and verify that valve position remains constant.

Comments:

Signature

Date

System Operator

I\&C Engineer

Project Engineer 
Checklist 4.2.5.32:

Revision: 1

Instrumentation and Controls Test

Date: Nov. 21, 1997

Loop 495 Recycle Tank Pump

OHF Tank Contents Removal Project Cold Test

Page 1 of 2

Oak Ridge National Laboratory, Oak Ridge, Tennessee

Prepared by: CDM Federal Programs Corporation

Initials Criteria

A. Review the associated displays for layout and completeness.

Display layout is correct and complete.

B. Point and display verification

Verify pump field switch status indicates Local at display.

Verify pump status indicates Off at display.

Select Computer Auto at display and verify pump status indicates Computer Auto at display.

Select Computer Manual at display and verify pump status indicates Computer Manual at display.

Change pump field switch to the Remote position and verify pump status changes to Remote at display.

C. Manual Control

With pump field switch in the Local position, Select pump Start at display and verify that pump does not Run.

Change pump field switch to the Remote position. Select pump Start at display and verify that pump status changes to Run at display.

Select pump Stop at display and verify that pump status changes to Off at display.

D. Equipment Failure

Disable pump from running. Select pump Start at display and verify pump status indicates Off at display. After 10 seconds, verify that an equipment failure alarm is generated. 


\begin{tabular}{|l|l|}
\hline $\begin{array}{c}\text { Checklist 4.2.5.32: } \\
\text { Instrumentation and Controls Test } \\
\text { Loop 495 Recycle Tank Pump }\end{array}$ & $\begin{array}{l}\text { Revision: 1 } \\
\text { Date: Nov. 21, 1997 }\end{array}$ \\
\hline $\begin{array}{l}\text { OHF Tank Contents Removal Project Cold Test } \\
\text { Oak Ridge National Laboratory, Oak Ridge, Tennessee }\end{array}$ & Page 2 of 2 \\
\hline Prepared by: CDM Federal Programs Corporation & \\
\hline
\end{tabular}

Select pump Start and verify PLC start output does not energize.

Select pump fail Reset at display. Enable pump to run and select pump Start at display and verify pump status changes to Run at display. Select pump Stop at display.

E. Interlocks

Select pump Start at display. With pump confirmed running, simulate a Loop 305 High High Intake Line Pressure Alarm. Verify a High High Intake Line Pressure Alarm is generated and after MOV 305 is open for 15 seconds, the pump is shut off.

Return Loop 305 pressure to normal. Verify pump does not restart.

Select pump Start at display. With pump confirmed running, simulate a Loop 305 High High Intake Line Pressure Alarm. Verify a High High Intake Line Pressure Alarm is generated. Return pressure to normal within 15 seconds and verify pump does not shut off.

Comments:

System Operator

1\&C Engineer

Project Engineer 
Checklist 4.2.5.33:

Revision: 1

Instrumentation and Controls Test

Date: Nov. 21, 1997

Loop 600 Sluicer Control Console Power

OHF Tank Contents Removal Project Cold Test

Page 1 of 1

Oak Ridge National Laboratory, Oak Ridge, Tennessee

Prepared by: CDM Federal Programs Corporation

Initials Criteria

A. Review the associated displays for layout and completeness.

Display layout is correct and complete.

B. Point and display verification

Using discrete input simulation equipment, simulate a sluicer control power on condition. Verify display indicates Power On status.

Using discrete input simulation equipment, simulate a sluicer control power off condition. Verify display indicates Power Off status.

Comments:

Signature

Date

System Operator

I\&C Engineer

Project Engineer 


\begin{tabular}{|l|l|}
\hline $\begin{array}{c}\text { Checklist 4.2.5.34: } \\
\text { Instrumentation and Controls Test } \\
\text { Loop 605 Sluicer Control Console System On }\end{array}$ & $\begin{array}{l}\text { Revision: 1 } \\
\text { Date: Nov. 21, } 1997\end{array}$ \\
\hline $\begin{array}{l}\text { OHF Tank Contents Removal Project Cold Test } \\
\text { Oak Ridge National Laboratory, Oak Ridge, Tennessee }\end{array}$ & Page 1 of 1 \\
\hline Prepared by: CDM Federal Programs Corporation & \\
\hline
\end{tabular}

Initials Criteria

A. Review the associated displays for layout and completeness.

Display layout is correct and complete.

B. Point and display verification

Using discrete input simulation equipment, simulate a sluicer control system on condition. Verify display indicates System On status.

Using discrete input simulation equipment, simulate a sluicer control system off condition. Verify display indicates System Off status.

Comments:

Signature

Date

System Operator

I\&C Engineer

Project Engineer 
Checklist 4.2.5.35:

Instrumentation and Controls Test

Revision: 1

Date: Nov. 21, 1997

Loop 610 Sluicer Control Console Emergency Stop

OHF Tank Contents Removal Project Cold Test

Page 1 of 1

Oak Ridge National Laboratory, Oak Ridge, Tennessee

Prepared by: CDM Federal Programs Corporation

Initials Criteria

A. Review the associated displays for layout and completeness.

Display layout is correct and complete.

B. Point and display verification

Using discrete input simulation equipment, simulate a sluicer control emergency stop condition. Verify an alarm is generated at display.

Using discrete input simulation equipment, simulate a sluicer control emergency stop clear condition. Verify alarm is cleared at display.

C. Manual Control

Select Emergency Stop at display and verify that output de-energizes.

Select Clear Emergency Stop at display and verify that output energizes.

Comments:

Signature

Date

System Operator

I\&C Engineer

Project Engineer 


\begin{tabular}{|l|l|}
\hline $\begin{array}{c}\text { Checklist 4.2.5.36: } \\
\text { Instrumentation and Controls Test } \\
\text { Loop 615 Sluicer System Hydraulic Power }\end{array}$ & $\begin{array}{l}\text { Revision: 1 } \\
\text { Date: Nov. 21, 1997 }\end{array}$ \\
\hline $\begin{array}{l}\text { OHF Tank Contents Removal Project Cold Test } \\
\text { Oak Ridge National Laboratory, Oak Ridge, Tennessee }\end{array}$ & Page 1 of 1 \\
\hline Prepared by: CDM Federal Programs Corporation & \\
\hline
\end{tabular}

Initials Criteria

A. Review the associated displays for layout and completeness.

Display layout is correct and complete.

B. Point and display verification

Using discrete input simulation equipment, simulate a sluicer system hydraulic power on condition. Verify display indicates Hydraulic Power On status.

Using discrete input simulation equipment, simulate a sluicer system hydraulic power off condition. Verify display indicates Hydraulic Power Off status.

Comments:

Signature

Date

System Operator

I\&C Engineer

Project Engineer 


\begin{tabular}{|l|l|}
\hline $\begin{array}{c}\text { Checklist 4.2.5.37: } \\
\text { Instrumentation and Controls Test } \\
\text { Loop 625 Sluicer System Pressure }\end{array}$ & $\begin{array}{l}\text { Revision: 1 } \\
\text { Date: Nov. 21, 1997 }\end{array}$ \\
\hline $\begin{array}{l}\text { OHF Tank Contents Removal Project Cold Test } \\
\text { Oak Ridge National Laboratory, Oak Ridge, Tennessee }\end{array}$ & Page 1. of 1 \\
\hline Prepared by: CDM Federal Programs Corporation & \\
\hline
\end{tabular}

Initials Criteria

A. Review the associated displays for layout and completeness.

Display layout is correct and complete.

B. Point and display verification

Using analog input simulation equipment, simulate a pressure signal. Verify that the engineering units conversion is performed correctly. Verify a Low alarm is generated at display.

Comments:

Signature

Date

System Operator

I\&C Engineer

Project Engineer 
Checklist 4.2.5.38:

Instrumentation and Controls Test

Revision: 1

Loop 630 Sluicer Arm Control Pressure

OHF Tank Contents Removal Project Cold Test

Date: Nov. 21, 1997

Oak Ridge National Laboratory, Oak Ridge, Tennessee

Prepared by: CDM Federal Programs Corporation

Initials Criteria

A. Review the associated displays for layout and completeness.

Display layout is correct and complete.

B. Point and display verification

Using analog input simulation equipment, simulate a pressure signal. Verify that the engineering units conversion is performed correctly. Verify a Low alarm is generated at display.

Comments:

Signature

Date

System Operator

I\&C Engineer

Project Engineer 


\begin{tabular}{|l|l|}
\hline $\begin{array}{c}\text { Checklist 4.2.5.39: } \\
\text { Instrumentation and Controls Test } \\
\text { Loop 635 Sluicer Extension Pressure }\end{array}$ & $\begin{array}{l}\text { Revision: 1 } \\
\text { Date: Nov. 21, 1997 }\end{array}$ \\
\hline $\begin{array}{l}\text { OHF Tank Contents Removal Project Cold Test } \\
\text { Oak Ridge National Laboratory, Oak Ridge, Tennessee }\end{array}$ & Page 1 of 1 \\
\hline Prepared by: CDM Federal Programs Corporation & \\
\hline
\end{tabular}

Initials Criteria

A. Review the associated displays for layout and completeness.

Display layout is correct and complete.

B. Point and display verification

Using analog input simulation equipment, simulate a pressure signal. Verify that the engineering units conversion is performed correctly. Verify a Low alarm is generated at display.

Comments:

Signature

Date

System Operator

I\&C Engineer

Project Engineer 


\begin{tabular}{|l|l|}
\hline $\begin{array}{c}\text { Checklist 4.2.5.40: } \\
\text { Instrumentation and Controls Test } \\
\text { Loop 640 Sluicer Mast Pressure }\end{array}$ & $\begin{array}{l}\text { Revision: 1 } \\
\text { Date: Nov. 21, } 1997\end{array}$ \\
\hline $\begin{array}{l}\text { OHF Tank Contents Removal Project Cold Test } \\
\text { Oak Ridge National Laboratory, Oak Ridge, Tennessee }\end{array}$ & Page 1 of 1 \\
\hline Prepared by: CDM Federal Programs Corporation & \\
\hline
\end{tabular}

Initials Criteria

A. Review the associated displays for layout and completeness.

Display layout is correct and complete.

B. Point and display verification

Using analog input simulation equipment, simulate a pressure signal. Verify that the engineering units conversion is performed correctly. Verify a Low alarm is generated at display.

Comments:

Signature

Date

System Operator

I\&C Engineer

Project Engineer 


\begin{tabular}{|l|l|}
\hline $\begin{array}{c}\text { Checklist 4.2.5.41: } \\
\text { Instrumentation and Controls Test } \\
\text { Loop 645 Sluicer Arm Range }\end{array}$ & $\begin{array}{l}\text { Revision: 1 } \\
\text { Date: Nov. 21, 1997 }\end{array}$ \\
\hline $\begin{array}{l}\text { OHF Tank Contents Removal Project Cold Test } \\
\text { Oak Ridge National Laboratory, Oak Ridge, Tennessee }\end{array}$ & Page 1 of 1 \\
\hline Prepared by: CDM Federal Programs Corporation & \\
\hline
\end{tabular}

Initials Criteria

A. Review the associated displays for layout and completeness.

Display layout is correct and complete.

B. Point and display verification

Using analog input simulation equipment, simulate a position signal. Verify that the engineering units conversion is performed correctly.

Comments:

Signature

Date

System Operator

I\&C Engineer

Project Engineer 


\begin{tabular}{|l|l|}
\hline $\begin{array}{c}\text { Checklist 4.2.5.42: } \\
\text { Instrumentation and Controls Test } \\
\text { Loop 650 Sluicer Arm Extension }\end{array}$ & $\begin{array}{l}\text { Revision: 1 } \\
\text { Date: Nov. 21, 1997 }\end{array}$ \\
\hline $\begin{array}{l}\text { OHF Tank Contents Removal Project Cold Test } \\
\text { Oak Ridge National Laboratory, Oak Ridge, Tennessee }\end{array}$ & Page 1 of 1 \\
\hline Prepared by: CDM Federal Programs Corporation & \\
\hline
\end{tabular}

Initials Criteria

A. Review the associated displays for layout and completeness.

Display layout is correct and complete.

B. Point and display verification

Using analog input simulation equipment, simulate a position signal. Verify that the engineering units conversion is performed correctly.

Comments:

Signature

Date

System Operator

I\&C Engineer

Project Engineer 


\begin{tabular}{|l|l|}
\hline $\begin{array}{c}\text { Checklist 4.2.5.43: } \\
\text { Instrumentation and Controls Test } \\
\text { Loop 655 Sluicer Mast Angle }\end{array}$ & $\begin{array}{l}\text { Revision: 1 } \\
\text { Date: Nov. 21, 1997 }\end{array}$ \\
\hline $\begin{array}{l}\text { OHF Tank Contents Removal Project Cold Test } \\
\text { Oak Ridge National Laboratory, Oak Ridge, Tennessee }\end{array}$ & Page 1 of 1 \\
\hline Prepared by: CDM Federal Programs Corporation & \\
\hline
\end{tabular}

Initials Criteria

A. Review the associated displays for layout and completeness.

Display layout is correct and complete.

B. Point and display verification

Using analog input simulation equipment, simulate a position signal. Verify that the engineering units conversion is performed correctly.

Comments:

Signature

Date

System Operator

I\&C Engineer

Project Engineer 
Checklist 4.2.5.44:

Instrumentation and Controls Test

Revision: 1

Loop 660 Sluicer Pump Intake Valve

OHF Tank Contents Removal Project Cold Test

Page 1 of 2

Oak Ridge National Laboratory, Oak Ridge, Tennessee

Prepared by: CDM Federal Programs Corporation

Initials Criteria

A. Review the associated displays for layout and completeness.

Display layout is correct and complete.

B. Point and display verification

Verify valve field switch status indicates Local at display.

Change valve field switch to the Remote position and verify valve status changes to Remote at display.

Select Computer Auto at display and verify status indicates Computer Auto at display.

Select Computer Manual at display and verify status indicates Computer Manual at display.

C. Manual Control

With valve field switch in the Close position, Select valve Open at display and verify that valve does not Open.

With valve field switch in the Open position, Select valve Close at display and verify that valve does not Close.

Change valve field switch to the Remote position. Select valve Open at display and verify that valve opens.

Select valve Close at display and verify that valve closes. 
Checklist 4.2.5.44:

Revision: 1

Instrumentation and Controls Test

Date: Nov. 21, 1997

Loop 660 Sluicer Pump Intake Valve

OHF Tank Contents Removal Project Cold Test

Page 2 of 2

Oak Ridge National Laboratory, Oak Ridge, Tennessee

Prepared by: CDM Federal Programs Corporation

Comments:

Signature

Date

System Operator

I\&C Engineer

Project Engineer 


\begin{tabular}{|l|l|}
\hline $\begin{array}{c}\text { Checklist 4.2.5.45: } \\
\text { Instrumentation and Controls Test } \\
\text { Loop 663 Sluicer Pump Intake Pressure }\end{array}$ & $\begin{array}{l}\text { Revision: 1 } \\
\text { Date: Nov. 21, 1997 }\end{array}$ \\
\hline $\begin{array}{l}\text { OHF Tank Contents Removal Project Cold Test } \\
\text { Oak Ridge National Laboratory, Oak Ridge, Tennessee }\end{array}$ & Page 1 of 1 \\
\hline Prepared by: CDM Federal Programs Corporation & \\
\hline
\end{tabular}

Initials Criteria

A. Review the associated displays for layout and completeness.

Display layout is correct and complete.

B. Point and display verification

Using analog input simulation equipment, simulate a pressure signal. Verify that the engineering units conversion is performed correctly. Verify a Low alarm is generated at display. Verify trend is functioning correctly.

Comments:

Signature

Date

System Operator

I\&C Engineer

Project Engineer 
Checklist 4.2.5.46:

Instrumentation and Controls Test

Revision: 1

Loop 665 Sluicer Pump

OHF Tank Contents Removal Project Cold Test

Date: Nov. 21, 1997

Oak Ridge National Laboratory, Oak Ridge, Tennessee

Prepared by: CDM Federal Programs Corporation

Initials Criteria

A. Review the associated displays for layout and completeness.

Display layout is correct and complete.

B. Point and display verification

Verify pump field switch status indicates Local at display.

Verify pump status indicates Off at display.

Select Computer Auto at display and verify pump status indicates Computer Auto at display.

Select Computer Manual at display and verify pump status indicates Computer Manual at display.

Change pump field switch to the Remote position and verify pump status changes to Remote at display.

Using discrete input simulation equipment, simulate a VFD Drive Fail state.

Verify an alarm is generated at display.

Using discrete input simulation equipment, simulate a VFD Drive Fail return to Normal state. Verify alarm is cleared at display.

Using discrete input simulation equipment, simulate a Pump Pressure Shutdown state. Verify an alarm is generated at display.

Using discrete input simulation equipment, simulate a Pump Pressure Shutdown return to Normal state. Verify alarm is cleared at display. 


\begin{tabular}{|l|l|}
\hline $\begin{array}{c}\text { Checklist 4.2.5.46: } \\
\text { Instrumentation and Controls Test } \\
\text { Loop 665 Sluicer Pump }\end{array}$ & $\begin{array}{l}\text { Revision: 1 } \\
\text { Date: Nov. 21, 1997 }\end{array}$ \\
\hline $\begin{array}{l}\text { OHF Tank Contents Removal Project Cold Test } \\
\text { Oak Ridge National Laboratory, Oak Ridge, Tennessee }\end{array}$ & Page 2 of 3 \\
\hline Prepared by: CDM Federal Programs Corporation & \\
\hline
\end{tabular}

\section{Manual Control}

With pump field switch in the Local position, Select pump Start at display and verify that pump does not Run.

Change pump field switch to the Remote position. Select pump Start at display and verify that pump status changes to Run at display.

Enter a pump speed set point of $100 \%$ at the display and verify that the pump speed indication is $100 \%$ at display.

Enter a pump speed set point of $50 \%$ at the display and verify that the pump speed indication is $50 \%$ at display.

Enter a pump speed set point of $0 \%$ at the display and verify that the pump speed indication is $0 \%$ at display.

Select pump Stop at display and verify that pump status changes to Off at display.

D. Equipment Failure

Disable pump from running. Select pump Start at display and verify pump status indicates Off at display. After 10 seconds, verify that an equipment failure alarm is generated.

Select pump Start and verify PLC start output does not energize.

Select pump fail Reset at display. Enable pump to run and select pump Start at display and verify pump status changes to Run at display. Select pump Stop at display.

E. Interlocks

Select pump Start at display. With pump confirmed running, simulate a VFD Drive Fail condition. Verify a VFD Drive Fail Alarm is generated and the pump is shut off. 


\begin{tabular}{|l|l|}
\hline $\begin{array}{c}\text { Checklist 4.2.5.46: } \\
\text { Instrumentation and Controls Test } \\
\text { Loop 665 Sluicer Pump }\end{array}$ & $\begin{array}{l}\text { Revision: 1 } \\
\text { Date: Nov. 21, 1997 }\end{array}$ \\
\hline $\begin{array}{l}\text { OHF Tank Contents Removal Project Cold Test } \\
\text { Oak Ridge National Laboratory, Oak Ridge, Tennessee }\end{array}$ & Page 3 of 3 \\
\hline Prepared by: CDM Federal Programs Corporation & \\
\hline
\end{tabular}

Remove VFD Drive Fail condition. Select pump Start at display. With pump confirmed running, simulate a Pump Pressure Shutdown condition. Verify a Pump Pressure Shutdown Alarm is generated and the pump is shut off.

Remove Pump Pressure Shutdown condition. Select pump Start at display. With pump confirmed running, simulate a Loop 445-2 High High Old Hydrofracture Tank Level condition. Verify a High High Old Hydrofracture Tank Level Alarm is generated and the pump is shut off.

Return Loop 445-2 level to normal. Verify pump does not restart.

Comments:

Signature

Date

System Operator

I\&C Engineer

Project Engineer 
Checklist 4.2.5.47:

Instrumentation and Controls Test

Revision: 1

Loop 665A Sluicer Pump Bypass Valve

OHF Tank Contents Removal Project Cold Test

Date: Nov. 21, 1997

Oak Ridge National Laboratory, Oak Ridge, Tennessee

Prepared by: CDM Federal Programs Corporation

Initials Criteria

A. Review the associated displays for layout and completeness.

- Display layout is correct and complete.

B. Point and display verification

Verify valve field switch status indicates Local at display.

Change valve field switch to the Remote position and verify valve status changes to Remote at display.

Select Computer Auto at display and verify status indicates Computer Auto at display.

Select Computer Manual at display and verify status indicates Computer Manual at display.

C. Manual Control

With valve field switch in the Close position, Select valve Open at display and verify that valve does not Open.

With valve field switch in the Open position, Select valve Close at display and verify that valve does not Close.

Change valve field switch to the Remote position. Select valve Open at display and verify that valve opens.

Select valve Close at display and verify that valve closes. 


\begin{tabular}{|l|l|}
\hline $\begin{array}{c}\text { Checklist 4.2.5.47: } \\
\text { Instrumentation and Controls Test } \\
\text { Loop 665A Sluicer Pump Bypass Valve }\end{array}$ & $\begin{array}{l}\text { Revision: 1 } \\
\text { Date: Nov. 21, 1997 }\end{array}$ \\
\hline $\begin{array}{l}\text { OHF Tank Contents Removal Project Cold Test } \\
\text { Oak Ridge National Laboratory, Oak Ridge, Tennessee }\end{array}$ & Page 2 of 2 \\
\hline Prepared by: CDM Federal Programs Corporation & \\
\hline
\end{tabular}

Comments:

Signature

Date

System Operator

I\&C Engineer

Project Engineer 
Checklist 4.2.5.48:

Instrumentation and Controls Test

Revision: 1

Loop 668 Sluicer Pump Discharge Pressure

Date: Nov. 21, 1997 and Loop 670 Sluicer Pressure Release Valve

OHF Tank Contents Removal Project Cold Test

Page 1 of 2

Oak Ridge National Laboratory, Oak Ridge, Tennessee

Prepared by: CDM Federal Programs Corporation

Initials Criteria

A. Review the associated displays for layout and completeness.

Display layout is correct and complete.

B. Point and display verification.

Verify valve field switch status indicates Local at display.

Change valve field switch to the Remote position and verify valve status changes to Remote at display.

Using analog input simulation equipment, simulate a pressure signal. Verify that the engineering units conversion is performed correctly. Verify a Low, High, and High High alarm is generated at display. Verify trend is functioning correctly.

C. Manual Control

With valve field switch in the Close position, select valve Open at display and verify that valve does not Open.

With valve field switch in the Open position, select valve Close at display and verify that valve does not Close.

Change valve field switch to the Remote position. Select valve Open at display and verify that valve Opens.

Select valve Close at display and verify that valve Closes.

D. Computer Interlocks

Simulate a pressure signal above the High alarm limit. Verify that the valve Opens. 


\begin{tabular}{|l|l|}
\hline $\begin{array}{c}\text { Checklist 4.2.5.48: } \\
\text { Instrumentation and Controls Test } \\
\text { Loop 668 Sluicer Pump Discharge Pressure } \\
\text { and Loop 670 Sluicer Pressure Release Valve }\end{array}$ & $\begin{array}{l}\text { Revision: 1 } \\
\text { Date: Nov. 21, 1997 }\end{array}$ \\
\hline $\begin{array}{l}\text { OHF Tank Contents Removal Project Cold Test } \\
\text { Oak Ridge National Laboratory, Oak Ridge, Tennessee }\end{array}$ & Page 2 of 2 \\
\hline Prepared by: CDM Federal Programs Corporation & \\
\hline
\end{tabular}

Simulate a pressure signal below the High alarm limit. Verify that the valve returns to the previous state.

Comments:

Signature

Date

System Operator

I\&C Engineer

Project Engineer 
Checklist 4.2.5.49:

Instrumentation and Controls Test

Revision: 0

Loop 675 Sluicer Pump Discharge Valve

OHF Tank Contents Removal Project Cold Test

Date: Aug. 29, 1997

Oak Ridge National Laboratory, Oak Ridge, Tennessee

Prepared by: CDM Federal Programs Corporation

Initials Criteria

A. Review the associated displays for layout and completeness.

Display layout is correct and complete.

B. Point and display verification

Verify valve field switch status indicates Local at display.

Change valve field switch to the Remote position and verify valve status changes to Remote at display.

Select Computer Auto at display and verify status indicates Computer Auto at display.

Select Computer Manual at display and verify status indicates Computer Manual at display.

C. Manual Control

With valve field switch in the Close position, Select valve Open at display and verify that valve does not Open.

With valve field switch in the Open position, Select valve Close at display and verify that valve does not Close.

Change valve field switch to the Remote position. Select valve Open at display and verify that valve opens.

Select valve Close at display and verify that valve closes. 


\begin{tabular}{|l|l|}
\hline $\begin{array}{c}\text { Checklist 4.2.5.49: } \\
\text { Instrumentation and Controls Test } \\
\text { Loop 675 Sluicer Pump Discharge Valve }\end{array}$ & $\begin{array}{l}\text { Revision: 0 } \\
\text { Date: Aug. 29, 1997 }\end{array}$ \\
\hline $\begin{array}{l}\text { OHF Tank Contents Removal Project Cold Test } \\
\text { Oak Ridge National Laboratory, Oak Ridge, Tennessee }\end{array}$ & Page 2 of 2 \\
\hline Prepared by: CDM Federal Programs Corporation & \\
\hline
\end{tabular}

Comments:

Signature

Date

System Operator

I\&C Engineer

Project Engineer 


\begin{tabular}{|l|l|}
\hline $\begin{array}{c}\text { Checklist 4.2.5.50: } \\
\text { Instrumentation and Controls Test } \\
\text { Loop 700 Radiation Monitor - Recycle Tank }\end{array}$ & $\begin{array}{l}\text { Revision: 1 } \\
\text { Date: Nov. 21, 1997 }\end{array}$ \\
\hline $\begin{array}{l}\text { OHF Tank Contents Removal Project Cold Test } \\
\text { Oak Ridge National Laboratory, Oak Ridge, Tennessee }\end{array}$ & Page 1 of 1 \\
\hline Prepared by: CDM Federal Programs Corporation & \\
\hline
\end{tabular}

Initials Criteria

A. Review the associated displays for layout and completeness.

Display layout is correct and complete.

B. Point and display verification

Using analog input simulation equipment, simulate a radiation signal. Verify that the engineering units conversion is performed correctly. Verify a High and High High alarm is generated at display. Verify trend is functioning correctly.

Comments:

Signature

Date

System Operator

I\&C Engineer

Project Engineer 


\begin{tabular}{|l|l|}
\hline $\begin{array}{c}\text { Checklist 4.2.5.51: } \\
\text { Instrumentation and Controls Test } \\
\text { Loop 705 Radiation Monitor - Hydrofracture Tank }\end{array}$ & $\begin{array}{l}\text { Revision: 1 } \\
\text { Date: Nov. 21, 1997 }\end{array}$ \\
\hline $\begin{array}{l}\text { OHF Tank Contents Removal Project Cold Test } \\
\text { Oak Ridge National Laboratory, Oak Ridge, Tennessee }\end{array}$ & Page 1 of 1 \\
\hline Prepared by: CDM Federal Programs Corporation & \\
\hline
\end{tabular}

Initials Criteria

A. Review the associated displays for layout and completeness.

Display layout is correct and complete.

B. Point and display verification

Using analog input simulation equipment, simulate a radiation signal. Verify that the engineering units conversion is performed correctly. Verify a High and High High alarm is generated at display. Verify trend is functioning correctly.

Comments:

Signature

Date

System Operator

I\&C Engineer

Project Engineer 


\begin{tabular}{|l|l|}
\hline $\begin{array}{c}\text { Checklist 4.2.5.52: } \\
\text { Instrumentation and Controls Test } \\
\text { Loop 710 Radiation Monitor - Pumping Skid }\end{array}$ & $\begin{array}{l}\text { Revision: 1 } \\
\text { Date: Nov. 21, } 1997\end{array}$ \\
\hline $\begin{array}{l}\text { OHF Tank Contents Removal Project Cold Test } \\
\text { Oak Ridge National Laboratory, Oak Ridge, Tennessee }\end{array}$ & Page 1 of 1 \\
\hline Prepared by: CDM Federal Programs Corporation & \\
\hline
\end{tabular}

Initials Criteria

A. Review the associated displays for layout and completeness.

Display layout is correct and complete.

B. Point and display verification

Using analog input simulation equipment, simulate a radiation signal. Verify that the engineering units conversion is performed correctly. Verify a High and High High alarm is generated at display. Verify trend is functioning correctly.

Comments:

Signature

Date

System Operator

I\&C Engineer

Project Engineer 
Checklist 4.3.1:

Revision: 1

Support System Test

Date: Nov. 21, 1997

Compressed Air System Inspection

OHF Tank Contents Removal Project Cold Test

Page 1 of 1

Oak Ridge National Laboratory, Oak Ridge, Tennessee

Prepared by: CDM Federal Programs Corporation

Initials Criteria

Air compressor is operating normally (i.e., no unusual noises or vibrations and no alarms on the control panel).

Air dryers are operating normally (i.e., no alarms on the control panel).

Air receiver tank pressure is psi.

Compressed air supply pressure is $100 \mathrm{psi}$.

Comments:

Signature

Date

System Operator

Project Engineer 


\begin{tabular}{|l|l|}
\hline $\begin{array}{c}\text { Checklist 4.3.2: } \\
\begin{array}{c}\text { Support SystemTest } \\
\text { Process Water Test }\end{array}\end{array}$ & $\begin{array}{l}\text { Revision: 1 } \\
\text { Date: Nov. 21, 1997 }\end{array}$ \\
\hline $\begin{array}{l}\text { OHF Tank Contents Removal Project Cold Test } \\
\text { Oak Ridge National Laboratory, Oak Ridge, Tennessee }\end{array}$ & Page 1 of 1 \\
\hline Prepared by: CDM Federal Programs Corporation & \\
\hline
\end{tabular}

Initials Criteria

Strainer STR355-1 flushed with process water while off-line.

Strainer STR355-2 flushed with wastewater while off-line.

Comments:

Signature

Date

System Operator

System Operator

Project Engineer 
Checklist 4.4.1:

Clean Water Capacity Test

Revision: 1

Submersible Pump Test

OHF Tank Contents Removal Project Cold Test

Date: Nov. 21, 1997

Oak Ridge National Laboratory, Oak Ridge, Tennessee

Page 1 of 1

Prepared by: CDM Federal Programs Corporation

Initials Criteria

Pump LPP495 started upon command from PLC.

Pump did not torque excessively on startup.

Deadhead pressure on pump was psi which is / is not (circle one) less than 75 psi.

Discharge pressure with MOV305 open $20 \%$ was psi, flow was gpm.

Discharge pressure with MOV305 open $40 \%$ was psi, flow was gpm.

Discharge pressure with MOV305 open $60 \%$ was psi, flow was gpm.

Discharge pressure with MOV305 open $80 \%$ was psi, flow was gpm.

Discharge pressure with MOV305 open $100 \%$ was psi, flow was gpm.

Pump LPP495 stopped upon command from PLC.

Comments:

Signature

Date

System Operator

System Operator

Project Engineer 


\begin{tabular}{|l|l|}
\hline $\begin{array}{c}\text { Checklist 4.4.2.1: } \\
\text { Clean Water Capacity Test } \\
\text { On-Line Strainer Flush Test }\end{array}$ & $\begin{array}{l}\text { Revision: 1 } \\
\text { Date: Nov. 21, 1997 }\end{array}$ \\
\hline $\begin{array}{l}\text { OHF Tank Contents Removal Project Cold Test } \\
\text { Oak Ridge National Laboratory, Oak Ridge, Tennessee }\end{array}$ & Page 1 of 1 \\
\hline Prepared by: CDM Federal Programs Corporation & \\
\hline
\end{tabular}

Initials Criteria

Strainer STR355-1 flushed with wastewater while on-line. Flow was ___ gpm.

Strainer STR355-2 flushed with wastewater while on-line. Flow was __ gpm.

Comments:

Signature

Date

System Operator

System Operator

Project Engineer 


\begin{tabular}{|l|l|}
\hline $\begin{array}{l}\text { Checklist 4.4.2.2: } \\
\text { Clean Water Capacity Test } \\
\text { Pump HPP320-1 Test }\end{array}$ & $\begin{array}{l}\text { Revision: 1 } \\
\text { Date: Nov. 21, 1997 }\end{array}$ \\
\hline $\begin{array}{l}\text { OHF Tank Contents Removal Project Cold Test } \\
\text { Oak Ridge National Laboratory, Oak Ridge, Tennessee }\end{array}$ & Page 1 of 2 \\
\hline Prepared by: CDM Federal Programs Corporation & \\
\hline
\end{tabular}

Initials Criteria

Pump HPP320-1 started upon command from PLC.

Pump does not have excessive vibration or belt slippage at $25 \%$ power.

Pressure readings at 25\% power are: PI305 and PI330 . Flow was gpm.

PLC alarmed at pump HPP320-2 intake pressure of psi.

PLC shut down pump HPP320-2 at an intake pressure of psi.

Pump does not have excessive vibration or belt slippage at $50 \%$ power.

Pressure readings at $50 \%$ power are: $\mathrm{PI} 305$ and PI330 . Flow was gpm.

Pump does not have excessive vibration or belt slippage at $75 \%$ power.

Pressure readings at $75 \%$ power are: $\mathrm{PI} 305$ and PI330 . Flow was gpm.

Pump does not have excessive vibration or belt slippage at $100 \%$ power.

Pressure readings at $100 \%$ power are: PI305 and PI330 . Flow was gpm.

PLC alarmed at pump HPP320-1 discharge pressure of psi.

PLC shut down pumps HPP320-1 and LPP495 at a discharge pressure of psi. Rupture disk RD325-1 failed at psi. 
Checklist 4.4.2.2:

Revision: 1

Clean Water Capacity Test

Date: Nov. 21, 1997

Pump HPP320-1 Test

OHF Tank Contents Removal Project Cold Test

Page 2 of 2

Oak Ridge National Laboratory, Oak Ridge, Tennessee

Prepared by: CDM Federal Programs Corporation

Comments:

Signature

Date

System Operator

System Operator

Project Engineer 


\begin{tabular}{|l|l|}
\hline $\begin{array}{c}\text { Checklist 4.4.2.3: } \\
\text { Clean Water Capacity Test } \\
\text { Pump HPP320-2 Test }\end{array}$ & $\begin{array}{l}\text { Revision: 1 } \\
\text { Date: Nov. 21, 1997 }\end{array}$ \\
\hline $\begin{array}{l}\text { OHF Tank Contents Removal Project Cold Test } \\
\text { Oak Ridge National Laboratory, Oak Ridge, Tennessee }\end{array}$ & Page 1 of 2 \\
\hline Prepared by: CDM Federal Programs Corporation & \\
\hline
\end{tabular}

Initials Criteria

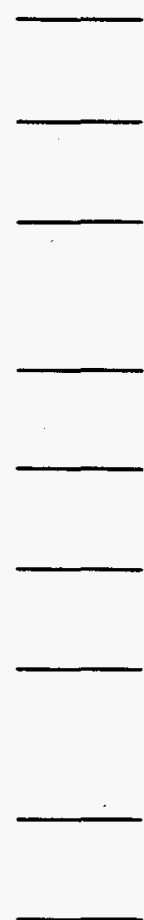

Pump HPP320-2 started upon command from PLC.

Pump does not have excessive vibration or belt slippage at $25 \%$ power.

Pressure readings at $25 \%$ power are: $\mathrm{PI} 305$ and PI330 . Flow was gpm.

PLC alarmed at pump HPP320-2 intake pressure of psi.

PLC shut down pump HPP320-2 at an intake pressure of psi.

Pump does not have excessive vibration or belt slippage at $50 \%$ power.

Pressure readings at 50\% power are: PI305 and PI330 . Flow was gpm.

Pump does not have excessive vibration or belt slippage at $75 \%$ power.

Pressure readings at $75 \%$ power are: PI305 and $\mathrm{PI} 330$ . Flow was gpm.

Pump does not have excessive vibration or belt slippage at $100 \%$ power.

Pressure readings at $100 \%$ power are: $\mathrm{Pl} 305$ and $\mathrm{PI} 330$ . Flow was gpm.

PLC alarmed at pump HPP320-2 discharge pressure of psi.

PLC shut down pumps HPP320-2 and LPP495 at a discharge pressure of psi. Rupture disk RD325-2 failed at psi. 


\begin{tabular}{|l|l|}
\hline $\begin{array}{c}\text { Checklist 4.4.2.3: } \\
\begin{array}{c}\text { Clean Water Capacity Test } \\
\text { Pump HPP320-2 Test }\end{array}\end{array}$ & $\begin{array}{l}\text { Revision: 1 } \\
\text { Date: Nov. 21, 1997 }\end{array}$ \\
\hline $\begin{array}{l}\text { OHF Tank Contents Removal Project Cold Test } \\
\text { Oak Ridge National Laboratory, Oak Ridge, Tennessee }\end{array}$ & Page 2 of 2 \\
\hline Prepared by: CDM Federal Programs Corporation & \\
\hline
\end{tabular}

Comments:

Signature

Date

System Operator

System Operator

Project Engineer 
Checklist 4.4.2.4:

Clean Water Cap: Test High Pressure Pu:

OHF Tank Contents Removal Project ( Oak Ridge National Laboratory, Oak R

Prepared by: CDM Federal Programs (

Initials

\section{Criteria}

High pressure switch PSH retested. It stopped pump

High pressure switch PSH retested. It stopped pump:

\begin{tabular}{l|l|}
\hline $\begin{array}{l}\text { Test } \\
\text { Reset }\end{array}$ & Revision: 1 \\
\hline $\begin{array}{l}\text { Test } \\
\text { Tennessee }\end{array}$ & Page 1 of 1 \\
\hline ration & \\
\hline
\end{tabular}

-1 was re-enabled after testing the rupture disk and 320-1 and LPP495 at psi.

2 was re-enabled after testing the rupture disk and

320-2 and LPP495 at psi.

\section{Comments:}

Signature

Date

System Operator

System Operator

Project Engineer 
Checklist 4.4.3:

Clean Water Capacity Test

Revision: 1

Sluicer Pump Test

OHF Tank Contents Removal Project Cold Test

Date: Nov. 21, 1997

Oak Ridge National Laboratory, Oak Ridge, Tennessee

Prepared by: CDM Federal Programs Corporation

Initials

Criteria

$\longrightarrow$

Pump SLCP665 started upon command from PLC.

Pump does not have excessive vibration or belt slippage at $25 \%$ power.

Pressure reading at 25\% power is: PI668 psi. Sluicing nozzle is functioning normally.

PLC alarmed at sluicer pump intake pressure of psi.

PLC shut system down at sluicer pump intake pressure of psi.

Pump does not have excessive vibration or belt slippage at $50 \%$ power.

Pressure reading at 50\% power is: PI668 psi. Sluicing nozzle is functioning normally.

Pump does not have excessive vibration or belt slippage at $75 \%$ power.

Pressure reading at $75 \%$ power is: $\mathrm{PI} 668$ psi. Sluicing nozzle is functioning normally.

Pump does not have excessive vibration or belt slippage at $100 \%$ power.

Pressure reading at $100 \%$ power is: PI668 psi. Sluicing nozzle is functioning normally. 
Checklist 4.4.3:

\section{Clean Water Capacity Test} Sluicer Pump Test

OHF Tank Contents Removal Project Cold Test

Oak Ridge National Laboratory, Oak Ridge, Tennessee

Prepared by: CDM Federal Programs Corporation
Revision: 1

Date: Nov. 21, 1997

Page 2 of 2

Comments:

Signature

Date

System Operator

System Operator

Project Engineer 


\begin{tabular}{|l|l|}
\hline $\begin{array}{l}\text { Checklist 4.5.1: } \begin{array}{c}\text { Sludge Pumping Test } \\
\text { Low Pressure Pumping Test }\end{array} \\
\text { OHF Tank Contents Removal Project Cold Test } \\
\text { Oak Ridge National Laboratory, Oak Ridge, Tennessee }\end{array}$ & $\begin{array}{l}\text { Revision: 1 } \\
\text { Date: Nov. 21, 1997 }\end{array}$ \\
\hline Prepared by: CDM Federal Programs Corporation & Page 1 \\
\hline
\end{tabular}

Initials Criteria

Pump winching mechanism operated properly.

Pump operated properly without locking or torquing significantly.

Comments:

Signature

Date

System Operator

I\&C Engineer

Project Engineer 
Checklist 4.5.2:

Revision: 1

Date: Nov. 21, 1997

Sluicing Test

OHF Tank Contents Removal Project Cold Test

Page 1 of 1

Oak Ridge National Laboratory, Oak Ridge, Tennessee

Prepared by: CDM Federal Programs Corporation

Initials

Criteria

PLC completed startup sequence on command.

PLC maintained system operation and balance relatively close to the set points specified by the operator.

Sluicer was able to suspend solids from the bottom of the tank.

System stopped on command from the PLC.

Comments:

Signature

Date

System Operator

System Operator

Project Engineer 
Appendix B

WORK INSTRUCTIONS 


\begin{tabular}{|l|l|}
\hline Work Instruction 1: Sluicing System Startup & $\begin{array}{l}\text { Revision: 1 } \\
\text { Date: Nov. 21, 1997 }\end{array}$ \\
\hline $\begin{array}{l}\text { OHF Tank Contents Removal Project Cold Test } \\
\text { Oak Ridge National Laboratory, Oak Ridge, Tennessee }\end{array}$ & Page 1 of 4 \\
\hline Prepared by: CDM Federal Programs Corporation & \\
\hline
\end{tabular}

Personnel: $\quad$ Three system operators.

Special Permits: None.

Special Tools: $\quad$ Two hand-held, 2-way radios.

Prerequisites: $\quad$ Before this operation, the sluicing system must be set up as described in Chaps. 2 and 3 of the Cold Test Plan. Additionally, the system must have successfully completed the system leak test, instrumentation and controls test, clean water capacity test, support systems test, and the sludge pumping test.

Work Instructions:

1. Verify the compressed air system is running. If it is not, start by method described in Work Instruction 2: Compressed Air System Startup.

2. Place local switch for the recycle tank submersible pump (LPP495) in the REMOTE position.

3. Place local switch for the high pressure pump (HPP320-1) in the REMOTE position.

4. Place local switch for sluicer pump (SLCP665) in the REMOTE position.

5. Place local switch for sluice tank submersible pump (LPP410-2) in the REMOTE position.

6. Place local switch for the hydraulic power unit in the REMOTE position.

7. Turn on in-tank video systems.

8. Turn on sluicer visualization system.

9. From the sluicer control panel, check sluicer arm angle movement, accuracy of control panel readout, accuracy of PLC readout, and accuracy of visualization system. 


\begin{tabular}{|l|l|}
\hline Work Instruction 1: Sluicing System Startup & $\begin{array}{l}\text { Revision: 1 } \\
\text { Date: Nov. 21, 1997 }\end{array}$ \\
\hline $\begin{array}{l}\text { OHF Tank Contents Removal Project Cold Test } \\
\text { Oak Ridge National Laboratory, Oak Ridge, Tennessee }\end{array}$ & Page 2 of 4 \\
\hline Prepared by: CDM Federal Programs Corporation & \\
\hline
\end{tabular}

10. From the sluicer control panel, check sluicer arm extension movement accuracy of control panel readout, accuracy of PLC readout, and accuracy of visualization system.

11. With one person at the sluicer control panel and one person visually observing the sluicer mast, check sluicer mast rotation movement, accuracy of control panel readout, accuracy of PLC readout, and accuracy of visualization system. Note any possible obstructions or objects that may catch the high pressure hose (line no. SF207-1).

12. From the sluicer control panel, map the coordinate locations of any in-tank obstructions with the sluice tank camera and the sluicer location readouts.

13. From the sluicer control panel, determine the arm angle and mast rotation angle for the sluice tank camera by aiming the sluicer nozzle at the camera.

14. From the sluicer control panel, determine the arm angle and mast rotation angle for the sluice tank submersible pump intake by aiming the sluicer nozzle at the pump intake.

15. From the sluicer control panel, position the sluicer arm in the area where you wish to begin sluicing.

16 From the PLC, close sluicer rinse valve MOV220-2.

17. From the PLC, close sluice tank camera rinse valve MOV225-1.

18. From the PLC, close recycle tank camera rinse valve MOV225-2.

19. From the PLC, close pipe flush valve MOV235.

20. Open process water source valve(s).

21. Open manual valve VLV315-1, high pressure pump HPP320-1 intake valve.

22. Open manual valve VLV330-1, high pressure pump HP320-1 discharge valve.

23. From the PLC, set actuated valve MOV305 (low pressure feed pump recycle valve) to $50 \%$ open. 


\begin{tabular}{|l|l|}
\hline Work Instruction 1: Sluicing System Startup & $\begin{array}{l}\text { Revision: 1 } \\
\text { Date: Nov. 21, 1997 }\end{array}$ \\
\hline $\begin{array}{l}\text { OHF Tank Contents Removal Project Cold Test } \\
\text { Oak Ridge National Laboratory, Oak Ridge, Tennessee }\end{array}$ & Page 3 of 4 \\
\hline Prepared by: CDM Federal Programs Corporation & \\
\hline
\end{tabular}

24. From the PLC, set actuated valve MOV340-1 (high pressure pump recycle valve) to $50 \%$ open.

25. From the PLC, close actuated valve MOV230, pipe blowdown valve.

26. Manually close sample port valve VLV310.

27. Manually close high pressure transfer pump \#2 valve VLV315-2.

28. Manually close high pressure transfer pump \#2 valve VLV330-2.

29. Manually open high pressure recycle valve VLV350.

30. Manually close strainer STR355-1 rinse valve VLV240-1.

31. Manually close strainer STR355-2 rinse valve VLV240-2.

32. Manually open strainer STR355-1 isolation valve VLV370-1.

33. Manually open strainer STR355-2 isolation valve VLV370-2.

34. From the PLC, open recycle tank submersible pump (LPP495) discharge valve MOV300.

35. From the PLC, close recycle tank bypass valve MOV250-1.

36. From the PLC, close recycle tank bypass valve MOV250-2.

37. From the PLC, close pipe flush valve MOV245.

38. From the PLC, close MVST discharge valve MOV340-2.

39. From the PLC, open strainer STR355-1 valve MOV350-1.

40. From the PLC, close strainer STR355-2 valve MOV350-2.

41. From the PLC, close strainer STR355-1 drain valve MOV360-1. 


\begin{tabular}{|l|l|}
\hline Work Instruction 1: Sluicing System Startup & $\begin{array}{l}\text { Revision: 1 } \\
\text { Date: Nov. 21, 1997 }\end{array}$ \\
\hline $\begin{array}{l}\text { OHF Tank Contents Removal Project Cold Test } \\
\text { Oak Ridge National Laboratory, Oak Ridge, Tennessee }\end{array}$ & Page 4 of 4 \\
\hline Prepared by: CDM Federal Programs Corporation & \\
\hline
\end{tabular}

42. From the PLC, close strainer STR355-2 drain valve MOV360-2.

43. From the PLC, open sluicer pump intake valve MOV660.

44. From the PLC, close sluicer pump bypass valve MOV665.

45. From the PLC, close sluicer pressure relief valve MOV670.

46. From the PLC, open sluicer pump discharge valve MOV675.

47. From the PLC, open sluice tank submersible pump (LPP410-2) discharge valve MOV410-2.

48. From the PLC, specify operation set points at the set point screen.

49. From the PLC, start the sluicing system and observe its operation until the system is shut down. During system operation, the PLC is not to be left unattended.

50. Once tank and pressure levels have stabilized at the desired set points, a system operator stationed at the sluicer control panel may begin moving the nozzle in the desired sluicing pattern. During system operation, the sluicer control panel is not to be left unattended.

51. During the entire operation, the third system operator will back up the operating team by observing with the in-tank cameras, periodically inspecting the equipment, and providing general support. 


\begin{tabular}{|l|l|}
\hline $\begin{array}{l}\text { Work Instruction 2: } \\
\text { Compressed Air System Startup }\end{array}$ & $\begin{array}{l}\text { Revision: 0 } \\
\text { Date: Aug. 29, 1997 }\end{array}$ \\
\hline $\begin{array}{l}\text { OHF Tank Contents Removal Project Cold Test } \\
\text { Oak Ridge National Laboratory, Oak Ridge, Tennessee }\end{array}$ & Page 1 of 1 \\
\hline Prepared by: CDM Federal Programs Corporation & \\
\hline
\end{tabular}

Personnel: $\quad$ One system operator.

Special Permits: None.

Special Tools: $\quad$ None

Prerequisites: $\quad$ Before this operation, the air compressor system must be installed as described in Chaps. 3 and 4 of the cold test plan.

Work Instructions:

1. From the PLC, close actuated valve MOV230.

2. Turn local switch for the air compressor skid to the on position.

3. Turn on the air dryer system and check the local control panel for alarms in accordance with manufacturer's instructions.

4. Turn on the air compressor and check the local control panel for alarms in accordance with manufacturer's instructions.

5. Monitor air receiver and pressure regulator valve pressures for overpressurization and adjust system as needed. Air receiver pressure should be $175 \mathrm{psi}$ and pressure regulator valve pressure should be 100 psi. 


\begin{tabular}{|l|l|}
\hline \multicolumn{1}{|c|}{ Work Instruction 3: } & $\begin{array}{l}\text { Revision: 0 } \\
\text { Date: Aug. 29, 1997 }\end{array}$ \\
\hline $\begin{array}{l}\text { OHF Tank Contents Removal Project Cold Test } \\
\text { Oak Ridge National Laboratory, Oak Ridge, Tennessee }\end{array}$ & Page 1 of 1 \\
\hline Prepared by: CDM Federal Programs Corporation & \\
\hline
\end{tabular}

Personnel: $\quad$ One system operator.

Special Permits: None.

Special Tools: None.

Prerequisites: During this operation, the sluicing system must be operating in a sluicing mode.

Notes: Valves listed normally are for flushing strainer STR355-1 while it is online. Valves in parentheses are for flushing strainer STR355-2 while it is on-line.

Work Instructions:

1. Note differential pressure across strainer.

2. Turn recycle tank camera toward strainer drain line discharge.

3. From the PLC, open strainer drain valve MOV360-1 (MOV360-2) and verify discharge with camera in recycle tank.

4. After operating for approximately 1 minute, close valve MOV360-1 (MOV360-2).

5. Check differential pressure across strainer. If pressure has not dropped sufficiently, repeat steps 3 and 4 until strainer is clean.

6. If the above method is not effective, switch strainers by Work Instruction 5 and flush strainer by Work Instruction 4 . 


\begin{tabular}{|l|l|}
\hline $\begin{array}{l}\text { Work Instruction 4: } \\
\text { Process Water Strainer Flushing }\end{array}$ & $\begin{array}{l}\text { Revision: 1 } \\
\text { Date: Nov. 21, 1997 }\end{array}$ \\
\hline $\begin{array}{l}\text { OHF Tank Contents Removal Project Cold Test } \\
\text { Oak Ridge National Laboratory, Oak Ridge, Tennessee }\end{array}$ & Page 1 of 2 \\
\hline Prepared by: CDM Federal Programs Corporation & \\
\hline
\end{tabular}

Personnel: $\quad$ Two system operators.

Special Permits: None.

Special Tools: $\quad$ None.

Prerequisites: The method in Work Instruction 3 did not effectively clean the strainer.

Notes: Valves listed normally are for flushing strainer STR355-1 while it is on-line. Valves in parentheses are for flushing strainer STR355-2 while it is on-line.

This work instruction may be used with the sluicing system on or off.

Work Instructions:

1. Verify strainer to be flushed is off-line by checking that the strainer inlet valve [MOV350-1 (MOV350-2)] is closed.

2. Turn recycle tank camera toward strainer drain line discharge.

3. Manually close valve VLV370-1 (VLV370-2).

4. Manually open valve VLV240-1 (VLV240-2).

5. From the PLC, open actuated valve MOV360-1 (MOV360-2).

6. From the PLC, open actuated valve MOV235 and verify discharge with camera in recycle tank.

7. After operating for approximately 2 minutes, close valve MOV235.

8. Repeat steps 6 and 7 twice.

9. Manually close VLV240-1 (VLV240-2). 


\begin{tabular}{|l|l|}
\hline $\begin{array}{c}\text { Work Instruction 4: } \\
\text { Process Water Strainer Flushing }\end{array}$ & $\begin{array}{l}\text { Revision: 1 } \\
\text { Date: Nov. 21, 1997 }\end{array}$ \\
\hline $\begin{array}{l}\text { OHF Tank Contents Removal Project Cold Test } \\
\text { Oak Ridge National Laboratory, Oak Ridge, Tennessee }\end{array}$ & Page 2 of 2 \\
\hline Prepared by: CDM Federal Programs Corporation & \\
\hline
\end{tabular}

10. From the PLC, close strainer drain valve MOV360-1 (MOV360-2).

11. Manually open VLV370-1 (VLV370-2).

12. Put strainer back on-line by the method in Work Instruction 5 .

13. If strainer continues to show high differential pressure, switch strainers by the method in Work Instruction 5 and change the strainer basket by method in Work Instruction 6 . 


\begin{tabular}{|l|l|}
\hline \multicolumn{1}{|l|}{ Work Instruction 5: } & $\begin{array}{l}\text { Revision: 0 } \\
\text { Date: Aug. 29, 1997 }\end{array}$ \\
\hline $\begin{array}{l}\text { OHF Tank Contents Removal Project Cold Test } \\
\text { Oak Ridge National Laboratory, Oak Ridge, Tennessee }\end{array}$ & Page 1 of 1 \\
\hline Prepared by: CDM Federal Programs Corporation & \\
\hline
\end{tabular}

Personnel: One system operator.

Special Permits: None.

Special Tools: None.

Prerequisites: The sluicing system is operating.

Notes: Valves listed normally are for switching from strainer STR355-1 to strainer STR355-2. Valves in parentheses are for switching from strainer STR355-2 to strainer STR355-1.

Work Instructions:

1. From the PLC, open actuated valve MOV350-2 (MOV350-1).

2. From the PLC, close actuated valve MOV350-1 (MOV350-2). 


\begin{tabular}{|l|l|}
\hline \multicolumn{1}{|c|}{ Work Instruction 6: } & $\begin{array}{l}\text { Revision: 1 } \\
\text { Date: Nov. 21, 1997 }\end{array}$ \\
\hline $\begin{array}{l}\text { OHF Tank Contents Removal Project Cold Test } \\
\text { Oak Ridge National Laboratory, Oak Ridge, Tennessee }\end{array}$ & Page 1 of 2 \\
\hline Prepared by: CDM Federal Programs Corporation & \\
\hline
\end{tabular}

Personnel: $\quad$ Two system operators.

Special Permits: Lockout/tagout for strainer to be repaired.

Special Tools: Impact socket, impact wrench, two open end wrenches, torque wrench (if required by manufacturer's instructions), socket wrench, replacement strainer basket, replacement strainer O-ring, spare nuts and bolts, and simulated radioactive waste container for used basket.

Prerequisites: $\quad$ The method in Work Instruction 4 did not effectively clean the strainer.

Notes: Valves listed normally are for changing the basket in strainer 1. Valves listed in parentheses are for changing the basket in strainer 2 .

This work instruction may be used with the sluicing system on or off.

Work Instructions:

1. From the PLC, open valve MOV360-1 (MOV360-2).

2. Close, lock out, and tag out valves VLV240-1 (VLV240-2), MOV350-1 (MOV350-2), MOV360-1 (MOV360-2), and VLV370-1 (VLV370-2).

3. Unbolt strainer top with impact wrench and open end wrench.

4. Remove strainer top and O-ring.

5. Remove strainer basket and place in container.

6. Insert new basket with slant facing toward influent side. 


\begin{tabular}{|l|l|}
\hline \multicolumn{1}{|c|}{ Work Instruction 6: } & $\begin{array}{l}\text { Revision: 1 } \\
\text { Date: Nov. 21, 1997 }\end{array}$ \\
\hline $\begin{array}{l}\text { OHF Tank Contents Removal Project Cold Test } \\
\text { Oak Ridge National Laboratory, Oak Ridge, Tennessee }\end{array}$ & Page 2 of 2 \\
\hline Prepared by: CDM Federal Programs Corporation & \\
\hline
\end{tabular}

7. Inspect O-ring. If damaged, place in container with basket and use new O-ring.

8. Place O-ring and top on strainer.

9. Check bolts and nuts. If damaged or rusted, place in container with basket and use new ones.

10. Tighten bolts with torque wrench to manufacturer's specifications (if applicable).

11. Remove lockout/tagout permit and locks.

12. Open valve VLV370-1 (VLV370-2). 


\begin{tabular}{|l|l|}
\hline \multicolumn{1}{|l|}{ Work Instruction 7: Normal System Shutdown } & $\begin{array}{l}\text { Revision: 1 } \\
\text { Date: Nov. 21, 1997 }\end{array}$ \\
\hline $\begin{array}{l}\text { OHF Tank Contents Removal Project Cold Test } \\
\text { Oak Ridge National Laboratory, Oak Ridge, Tennessee }\end{array}$ & Page 1 of 1 \\
\hline Prepared by: CDM Federal Programs Corporation & \\
\hline
\end{tabular}

Personnel: $\quad$ Three system operators and $I \& C$ engineer.

Special Permits: None.

Special Tools: None.

Prerequisites: The system must be operating normally and in a sluicing or MVST transfer mode.

Work Instructions:

1. Verify all waste has been transferred to the desired location and the system is ready to be shut down.

2. From the PLC, initiate system shutdown.

3. Retract the extendable nozzle into the mast.

4. Perform line flushing by method in Work Instruction 14 . 


\begin{tabular}{|l|l|}
\hline $\begin{array}{l}\text { Work Instruction 8: } \\
\text { Emergency System Shutdown }\end{array}$ & $\begin{array}{l}\text { Revision: 1 } \\
\text { Date: Nov. 21, 1997 }\end{array}$ \\
\hline $\begin{array}{l}\text { OHF Tank Contents Removal Project Cold Test } \\
\text { Oak Ridge National Laboratory, Oak Ridge, Tennessee }\end{array}$ & Page 1 of 1 \\
\hline Prepared by: CDM Federal Programs Corporation & \\
\hline
\end{tabular}

Personnel: $\quad$ Three system operators.

Special Permits: None.

Special Tools: $\quad$ None.

Prerequisites: None.

Work Instructions:

1. If the PLC has not initiated an automatic shutdown, initiate one manually by pressing the emergency stop button at the PLC.

2. Determine and document the cause of/reason for the emergency shutdown.

3. Notify the lead engineer (or designee).

4. If the situation allows and the lead engineer (or designee) approves, retract the extendible nozzle into the mast.

5. If the situation allows and the lead engineer (or designee) approves, perform line flushing by method in Work Instruction 14 . 


\begin{tabular}{|l|l|}
\hline Work Instruction 9: Line Leak Response & $\begin{array}{l}\text { Revision: 1 } \\
\text { Date: Nov. 21, 1997 }\end{array}$ \\
\hline $\begin{array}{l}\text { OHF Tank Contents Removal Project Cold Test } \\
\text { Oak Ridge National Laboratory, Oak Ridge, Tennessee }\end{array}$ & Page 1 of 1 \\
\hline Prepared by: CDM Federal Programs Corporation & \\
\hline
\end{tabular}

Personnel: $\quad$ Three system operators.

Special Permits: None.

Special Tools: None.

Prerequisites: None.

Work Instructions:

1. Verify the PLC has started the appropriate skid drip pan pump.

2. Turn the site cameras toward the drip pan that alarmed and start the video recorder.

3. From the PLC, stop the sluicing system pump.

4. Perform line flushing by method in Work Instruction 14 .

5. Retract the extendible nozzle into the sluicer mast.

6. Document the leak.

7. Notify the lead engineer (or designee). 


\begin{tabular}{|l|l|}
\hline Work Instruction 10: & $\begin{array}{l}\text { Revision: 1 } \\
\text { Date: Nov. 21, 1997 }\end{array}$ \\
\hline $\begin{array}{l}\text { OHF Tank Contents Removal Project Cold Test } \\
\text { Oak Ridge National Laboratory, Oak Ridge, Tennessee }\end{array}$ & Page 1 of 3. \\
\hline Prepared by: CDM Federal Programs Corporation & \\
\hline
\end{tabular}

Personnel: $\quad$ Crane operator, rigging crew, rigging foreman, one system operator, and project engineer.

Special Permits: $\quad$ Lockout/tagout for sluicer disconnection.

Special Tools: $\quad$ Extendible nozzle operations manuals,

crane,

rigging,

wrenches,

impact wrench,

18 -in. blind flange plate,

flange plate nuts and bolts,

18 -in. flange gasket, and.

torque wrench.

Prerequisites: During this operation, the sluicing system must not be operating.

Work Instructions:

1. With the sluice tank camera, verify the sluicer nozzle is fully retracted into the mast.

2. From the PLC, close the sluice tank camera rinse valve (MOV225-1).

3. From the PLC, close the recycle tank camera rinse valve (MOV225-2).

4. From the PLC, close the pipe flush valve (MOV235).

5. From the PLC, close the sluicer rinse valve (MOV220-2).

6. Open the process water source valve.

7. From the PLC, open the sluicer rinse valve (MOV220-2).

8. Wait 5 minutes. 


\begin{tabular}{|l|l|}
\hline \multicolumn{1}{|l|}{ Work Instruction 10: } & $\begin{array}{l}\text { Revision: 1 } \\
\text { Date: Nov. 21, 1997 }\end{array}$ \\
\hline $\begin{array}{l}\text { OHF Tank Contents Removal Project Cold Test } \\
\text { Oak Ridge National Laboratory, Oak Ridge, Tennessee }\end{array}$ & Page 2 of 3 \\
\hline Prepared by: CDM Federal Programs Corporation & \\
\hline
\end{tabular}

9. From the PLC, close the sluicer rinse valve (MOV220-2) and use flowmeter FE210 to record the volume of water used.

10. Wait a minimum of 1 hour to allow the excess rinse water to drip off the sluicer.

11. Lock out/ tag out appropriate equipment and valves.

12. Disconnect the hoses and electrical cables from the quick disconnects.

13. Connect the crane tackle to the lifting lug on the top of the sluicer mast.

14 Lift the mast until the sluicer weight is just beginning to come off the platform feet and hold.

15. Remove the bolts and gasket from the blind flange cover of the riser that the sluicer is to be moved to. Leave the blind flange plate on the riser.

16. Release the lower containment adapter clamps and clamp on the lower containment adapter cover plate on the sluicer bellows.

17. Place the flange plate over the riser opening of the tank that the sluicer is being moved from.

18. Attach tag lines to the sluicer platform.

19. Clear the immediate area of any personnel not directly involved in moving the sluicer.

20. Lift the mast and platform from the first tank and place on the second tank.

21. Set the clocking angle of the platform relative to the centerline of the tank.

22. Adjust the platform legs to level the platform and provide the correct height relative to the riser flange.

23. Remove the blind flange plate from the riser and bag for storage. 


\begin{tabular}{|l|l|}
\hline \multicolumn{1}{|c|}{ Work Instruction 10: } & $\begin{array}{l}\text { Revision: 1 } \\
\text { Date: Nov. 21. 1997 }\end{array}$ \\
\hline $\begin{array}{l}\text { OHF Tank Contents Removal Project Cold Test } \\
\text { Oak Ridge National Laboratory, Oak Ridge, Tennessee }\end{array}$ & Page 3 of 3 \\
\hline Prepared by: CDM Federal Programs Corporation & \\
\hline
\end{tabular}

24. Remove the lower containment adapter cover plate and clamp on the lower containment adapter to the riser.

25. Place the gasket and bolt down the blind flange plate on the first tank's riser. Torque to gasket manufacturer's specifications.

26. Lower the mast into the tank, ensuring that the mast key is properly engaged in the bridge mount clamp.

27. Disconnect the crane from the sluicer.

28. Reconnect the hoses and electrical cables to the appropriate quick disconnects.

29. Place the high pressure hose feeding slurry to the sluicer so that it will not become entangled during sluicer operation.

30. Remove the lockout/tagout permit. 


\begin{tabular}{|l|l|}
\hline Work Instruction 11: Camera Movement & $\begin{array}{l}\text { Revision: 0 } \\
\text { Date: Aug. 29, 1997 }\end{array}$ \\
\hline $\begin{array}{l}\text { OHF Tank Contents Removal Project Cold Test } \\
\text { Oak Ridge National Laboratory, Oak Ridge, Tennessee }\end{array}$ & Page 1 of 2 \\
\hline Prepared by: CDM Federal Programs Corporation & \\
\hline
\end{tabular}

Personnel: $\quad$ Crane operator, rigging crew, rigging foreman, and one system operator.

Special Permits: None.

Special Tools: $\quad$ Crane,

Rigging,

Wrenches,

Spare nuts and bolts, and

Spare gasket.

Prerequisites: During this operation, the sluicing system must not be operating.

Work Instructions:

1. Manually close the process water supply valve(s).

2. Turn off the in-tank video system.

3. Disconnect the camera lens rinse line.

4. Disconnect the camera power/communications cable.

5. Unbolt the camera mounting flange.

6. Connect the crane to the camera lifting lug.

7. Carefully pull camera with the crane.

8. Inspect the gasket and replace if necessary.

9. Carefully lower the camera into the desired location with gasket in place.

10. Position the gasket and place nuts/bolts finger tight.

11. Disconnect crane from lifting lug. 


\begin{tabular}{|l|l|}
\hline Work Instruction 11: Camera Movement & $\begin{array}{l}\text { Revision: 0 } \\
\text { Date: Aug. 29, 1997 }\end{array}$ \\
\hline $\begin{array}{l}\text { OHF Tank Contents Removal Project Cold Test } \\
\text { Oak Ridge National Laboratory, Oak Ridge, Tennessee }\end{array}$ & Page 2 of 2 \\
\hline Prepared by: CDM Federal Programs Corporation & \\
\hline
\end{tabular}

12. Tighten nuts/bolts with wrenches.

13. Reconnect power/communication cable.

14. Reconnect lens rinse line.

15. Manually open the process water supply valve(s).

16. Turn on camera system and verify proper operation and zero camera angle and rotation tracking. 


\begin{tabular}{|l|l|}
\hline $\begin{array}{l}\text { Work Instruction 12: } \\
\text { Replacing/Tightening Pump Belts }\end{array}$ & $\begin{array}{l}\text { Revision: 0 } \\
\text { Date: Aug. 29, 1997 }\end{array}$ \\
\hline $\begin{array}{l}\text { OHF Tank Contents Removal Project Cold Test } \\
\text { Oak Ridge National Laboratory, Oak Ridge, Tennessee }\end{array}$ & Page 1 of 2 \\
\hline Prepared by: CDM Federal Programs Corporation & \\
\hline
\end{tabular}

Personnel: $\quad$ Two system operators.

Special Permits: $\quad$ Lockout/tagout for pump being repaired.

Special Tools: Ratchet,

Open-end wrenches,

Pry bar, and

Replacement belt.

Prerequisites: None.

Work Instructions:

1. Lockout/tagout pump to be repaired.

2. Remove belt guard from the pump/motor assembly.

3. Inspect belt for wear or damage.

4. If belt was thrown off, compare length with length of replacement belt to determine if it has excessive stretching.

5. If belt has excessive wear, damage, or stretching, discard and replace with new belt.

6. Inspect pump and motor pulleys. They should be tight on the shaft and there should be minimal wobble or play in the shaft.

7. Determine if the mechanism for tightening the belt involves moving the motor or moving an adjustment pulley.

8. Loosen the bolts holding the belt adjustment in place.

9. If belt does not need replacement and is just loose on the pump, skip steps 10 and 11 


\begin{tabular}{|l|l|}
\hline $\begin{array}{l}\text { Work Instruction 12: } \\
\text { Replacing/Tightening Pump Belts }\end{array}$ & $\begin{array}{l}\text { Revision: 0 } \\
\text { Date: Aug. 29, 1997 }\end{array}$ \\
\hline $\begin{array}{l}\text { OHF Tank Contents Removal Project Cold Test } \\
\text { Oak Ridge National Laboratory, Oak Ridge, Tennessee }\end{array}$ & Page 2 of 2 \\
\hline Prepared by: CDM Federal Programs Corporation & \\
\hline
\end{tabular}

10. If the belt is on the pump and to be replaced, remove and discard it.

11. Place new belt (or the belt that was thrown) onto the pulley mechanism.

12. Using the pry bar, move the belt adjustment mechanism so that the belt is tight.

13. If the mechanism involves moving the motor, check the motor alignment with the pulley on the pump. The motor and motor pulley must be lined square with the pump pulley.

14. With the belt tight and the motor square, tighten the bolts, locking the adjustment mechanism in place while using the pry bar to assure the mechanism does not slip.

15. Inspect the belt for tightness and proper alignment in the pulleys.

16. Inspect the motor and motor pulley for squareness with the pump pulley.

17. Replace the belt guard on the pump.

18. Remove the lockout/tagout permit. 


\begin{tabular}{|l|l|}
\hline $\begin{array}{l}\text { Work Instruction 13: } \\
\text { Rupture Disk Replacement }\end{array}$ & $\begin{array}{l}\text { Revision: 1 } \\
\text { Date: Nov. 21, 1997 }\end{array}$ \\
\hline $\begin{array}{l}\text { OHF Tank Contents Removal Project Cold Test } \\
\text { Oak Ridge National Laboratory, Oak Ridge, Tennessee }\end{array}$ & Page 1 of 1 \\
\hline Prepared by: CDM Federal Programs Corporation & \\
\hline
\end{tabular}

Personnel: $\quad$ Two system operators.

Special Permits: Lockout/tagout for rupture disk being repaired.

Special Tools: $\quad$ Torque wrench,

Ratchet,

Open-end wrenches,

Spare nuts and bolts,

Spare gaskets, and

Replacement rupture disk.

Prerequisites: None.

Work Instructions:

1. Lockout/tagout rupture disk to be repaired.

2. Unbolt rupture disk holder and remove from the line.

3. Compare the label on the removed rupture disk with the label on the replacement disk to verify the replacement disk is the correct unit.

4. Remove the old rupture disk from the holder and place the new one in it with the curved-out side facing the high pressure side ("upstream").

5. Inspect the old gaskets for damage; replace if necessary.

6. Place the rupture disk holder back in the line with the curved-out side facing the high pressure side ("upstream").

7. Tighten the rupture disk holder in place to the manufacturer's recommended torque specifications.

8. Remove the lockout/tagout permit. 


\begin{tabular}{|l|l|}
\hline $\begin{array}{l}\text { Work Instruction 14: Line Flushing Sequence } \\
\text { OHF Tank Contents Removal Project Cold Test } \\
\text { Oak Ridge National Laboratory, Oak Ridge, Tennessee }\end{array}$ & $\begin{array}{l}\text { Revision: 0 } \\
\text { Date: Nov. 21, 1997 }\end{array}$ \\
\hline Prepared by: CDM Federal Programs Corporation & Page 3 \\
\hline
\end{tabular}

Personnel: $\quad$ Two system operators.

Special Permits: None.

Special Tools: None

Prerequisites: None.

Work Instructions:

1. Record totalized flow from FE210, process water flowmeter.

2. Close all actuated valves.

3. Open actuated valve MOV235, pipe flush valve.

\section{Low Pressure Transfer System Flushing}

4. Open actuated valve MOV250-2, recycle tank bypass valve.

5. Cycle actuated valve MOV410-2 (pump LPP410-2 discharge valve) open, then closed. Note: The valves have a 30 -second response time for full open to full close and vice versa.

6. Cycle actuated valve MOV455 (low pressure transfer throttle valve) open, then closed.

7. Close actuated valve MOV250-2, recycle tank bypass valve.

\section{Low Pressure Feed System Flushing}

8. Open actuated valve MOV250-1, recycle tank bypass valve.

9. Cycle actuated valve MOV300 (feed pump discharge valve) open, then closed.

10. Cycle actuated valve MOV305 (feed pump recycle valve) open, then closed. 


\begin{tabular}{|l|l|}
\hline Work Instruction 14: Line Flushing Sequence & $\begin{array}{l}\text { Revision: 0 } \\
\text { Date: Nov. 21, 1997 }\end{array}$ \\
\hline $\begin{array}{l}\text { OHF Tank Contents Removal Project Cold Test } \\
\text { Oak Ridge National Laboratory, Oak Ridge, Tennessee }\end{array}$ & Page 2 of 3 \\
\hline Prepared by: CDM Federal Programs Corporation & \\
\hline
\end{tabular}

\section{High Pressure Pump System}

11. Open actuated valve MOV340-1, high pressure pump recycle valve.

12. Note the totalized flow from process water flowmeter (FE210).

13. Start the high pressure pump being used (HPP320-1 or HPP320-2) at the lowest power setting.

14. After 60 gallons (by FE210) have been flushed through, shut down the pump.

15. Close actuated valve MOV340-1, high pressure pump recycle valve.

16. Close actuated valve MOV250-1, recycle tank bypass valve.

\section{Strainer Flushing}

17. Open actuated valve MOV245, pipe flush valve.

18. Open actuated valve MOV350-1, strainer STR355-1 valve.

19. Cycle actuated valve MOV360-1 (strainer STR355-1 drain valve) open, then closed.

20. Close actuated valve MOV350-1, strainer STR355-1 valve.

21. Open actuated valve MOV350-2, strainer STR355-2 valve.

22. Cycle actuated valve MOV360-2 (strainer STR355-2 drain valve) open, then closed.

\section{Sluicer and Sluicer Pump Flushing}

23. Open actuated valve MOV350-1, strainer STR355-1 valve.

24. Open actuated valve MOV660, sluicer pump (SLCP665) intake valve.

25. Open actuated valve MOV675, sluicer pump (SLCP665) discharge valve. 


\begin{tabular}{|l|l|}
\hline \multicolumn{1}{|l|}{ Work Instruction 14: Flushing Sequence } & $\begin{array}{l}\text { Revision: 0 } \\
\text { Date: Nov. 21, 1997 }\end{array}$ \\
\hline $\begin{array}{l}\text { OHF Tank Contents Removal Project Cold Test } \\
\text { Oak Ridge National Laboratory, Oak Ridge, Tennessee }\end{array}$ & Page 3 of 3 \\
\hline Prepared by: CDM Federal Programs Corporation & \\
\hline
\end{tabular}

26. Note the totalized flow from process water flowmeter (FE210).

27. Start the sluicer pump (SLCP665) at the lowest power setting.

28. After 30 gallons (by FE210) have been flushed through, shut down the pump.

29. Close actuated valve MOV660, sluicer pump (SLCP665) intake valve.

30. Cycle actuated valve MOV665 (sluicer pump (SLCP665) bypass valve) open, then closed.

Shutdown

31. Close actuated valve MOV245, pipe flush valve.

32. Close actuated valve MOV235, pipe flush valve.

33. Record volume of process water used in this line flushing sequence (current totalized flow from FE210 minus totalized flow recorded in step 1). 